\title{
ANÁLISE ECONÔMICA DO MANEJO DA CAIXETA - Tabebuia cassinoides (Lam.) DC NA REGIÃO DO VALE DO RIBEIRA-SP: UM ESTUDO DE CASO
}

ROBERTA CRISTINA FERREIRA CASTRO

Dissertação apresentada à Escola Superior

de Agricultura "Luiz de Queiroz", Universidade de São Paulo, para obtenção do título de Mestre em Ciências, Área de Concentração: Economia Aplicada.

\author{
P I R A C I C A B A \\ Estado de São Paulo - Brasil
}

Novembro -2002 


\section{ANÁLISE ECONÔMICA DO MANEJO DA CAIXETA - Tabebuia cassinoides (Lam.) DC NA REGIÃO DO VALE DO RIBEIRA-SP: UM ESTUDO DE CASO}

ROBERTA CRISTINA FERREIRA CASTRO

Bacharel em Administração de Empresas

Orientador: Prof. Dr. RICARDO SHIROTA

Dissertação apresentada à Escola Superior de Agricultura "Luiz de Queiroz", Universidade de São Paulo, para obtenção do título de Mestre em Ciências, Área de Concentração: Economia Aplicada.

P I R A C I C A B A

Estado de São Paulo - Brasil

Novembro -2002 


\title{
Dados Internacionais de Catalogação na Publicação (CIP)
} DIVISÃO DE BIBLIOTECA E DOCUMENTAÇÃO - ESALQ/USP

\author{
Castro, Roberta Cristina Ferreira \\ Análise econômica do manejo da caixeta - Tabebuia cassinoides (Lam.) \\ DC na região do Vale do Ribeira - SP : um estudo de caso / Roberta Cristina \\ Ferreira Castro. - - Piracicaba, 2002. \\ 117 p. : il. \\ Dissertação (mestrado) - - Escola Superior de Agricultura Luiz de Queiroz, \\ 2002. \\ Bibliografia. \\ 1. Análise econômica 2. Árvore florestal 3. Caixeta 4. Rentabilidade 5. \\ Vale do Ribeira (SP) I. Título
}

CDD 338.17497354

\section{"Permitida a cópia total ou parcial deste documento, desde que citada a fonte - $O$ autor"}


Para os meus pais, que me deram oportunidade de conhecer, e fazer, Ciência 


\section{AGRADECIMENTOS}

Ao professor Ricardo Shirota, que despertou meu profundo interesse em descobrir o que é, e como fazer, Ciência. Tive muita honra em ser orientada por um grande professor, não apenas por sua presente orientação e excelentes aulas, mas por sua simplicidade, honestidade, amizade e integridade profissional.

Ao engenheiro florestal Ricardo Bernhardt (ESALQ-USP) e ao técnico florestal Rui A. Paulo (DEPRN-Registro/SP), pela constante disponibilidade em responder às muitas dúvidas e ao fornecimento de dados e informações que foram essenciais para a obtenção dos resultados desse trabalho. À professora Adriana Nolasco, que notou a importância em analisar a rentabilidade do manejo da caixeta para produtores da região do Vale do Ribeira-SP e, ainda, por seu desprendimento em responder aos muitos questionamentos ocorridos durante o desenvolvimento da pesquisa. A biológa Mariana Carvalhaes (UFSCAR) pelo apoio dado na familiarização com os caixetais por meio de embasamentos teóricos e da integração com todos, hoje, que acreditam e investem no aprofundamento de conhecimentos científicos sobre a espécie.

Ao Instituto de Manejo e Certificação Florestal (IMAFLORA) e ao Programa da Terra (PROTER) que sempre atenderam a pedidos relativos ao fornecimento de informações.

À Coordenadoria de Assistência Técnica e Integral (CATI) do município de Registro, em nome do Engenheiro Agrônomo Luiz Antônio Campos Penteado, que me forneceram todas os dados e informações necessárias para a compreensão e análise do cultivo da banana na região de estudo. 
Aos funcionários do Alojamento do Instituto Brasileiro do Meio Ambiente e dos Recursos Naturais Renováveis (IBAMA) de Iguape-SP, que sempre me acolheram com grande simpatia durante às vezes em que precisei ir à campo. Quero agradecer a todos os proprietários de terra (caixetal), caixeteiros, a serraria da Associação dos Caixeteiros de Iguape, a marcenaria dos Jovens da Juréia, a serraria JP da Silva de Miracatu-SP, e a todos que compõem a Rede Caixeta. Sem a participação de todos eles não teria sido possível a realização da pesquisa de campo.

A CAPES pelo apoio financeiro concedido durante parte do período de pesquisa.

Aos demais professores do Departamento de Economia Administração e Sociologia da ESALQ, pelo embasamento teórico necessário ao desenvolvimento desse estudo.

Aos meus companheiros de mestrado, com quem pude compartilhar descobertas, alegrias, questionamentos e ansiedades. Em especial, à minha amiga Isabel Viegas que sempre foi uma grande companheira.

Ao meu querido Vitor, pela dedicação e incansável disciplina. Em nossas muitas conversas discutimos idéias e opiniões, as quais sua personalidade e valores me ensinaram a ver o mundo de uma forma diferente.

Aos meus irmãos, Marcus e Flávio, pelo incentivo e carinho durante todos esses anos. E, ainda, por terem me ensinado a importância e o valor de ampliar o conhecimento.

Por fim, gostaria de agradecer aos meus pais, Damião e Maria Zélia, que sempre me apoiaram e me deram força para que eu pudesse encontrar as respostas para muitos de meus questionamentos e, assim, conquistar meus objetivos. 


\section{SUMÁRIO}

Página

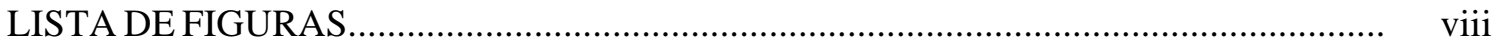

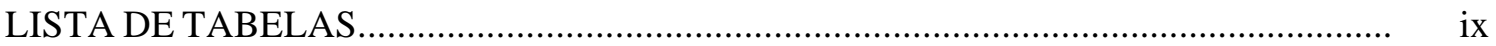

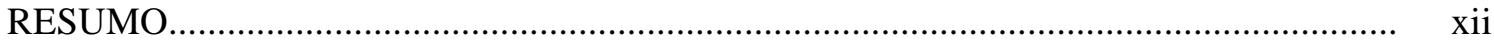

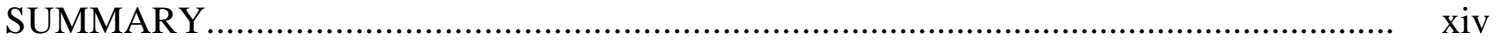

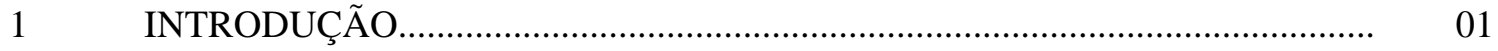

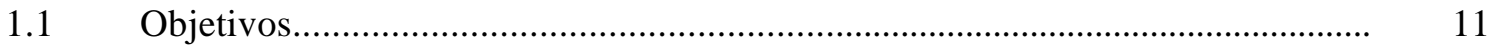

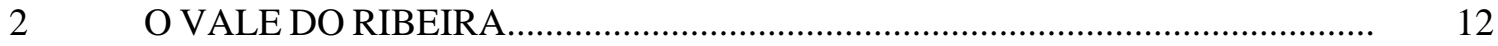

3 A CAIXETA - Tabebuia cassinoides (Lam.) DC................................................. 20

3.1 Descrição botânica............................................................................................ 20

3.2 Ciclo de exploração da caixeta......................................................................... 23

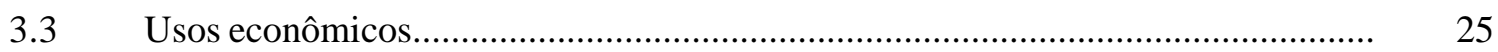

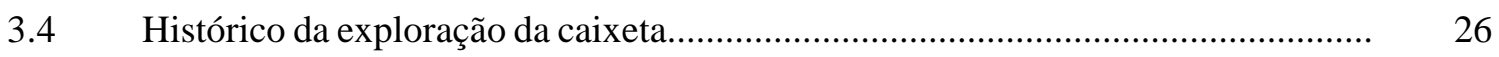

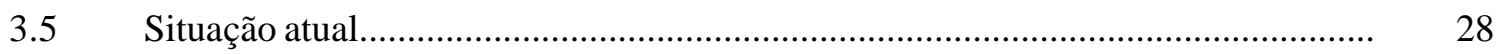

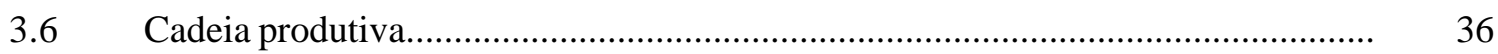

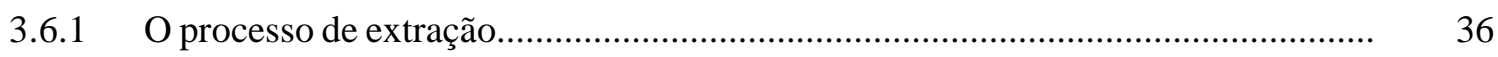

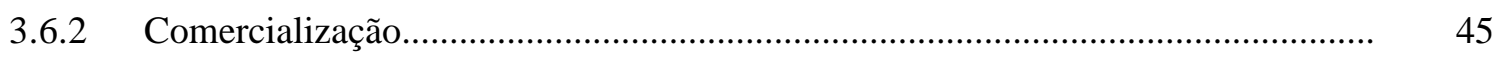

3.6.3 Evolução do preço da caixeta........................................................................... 47

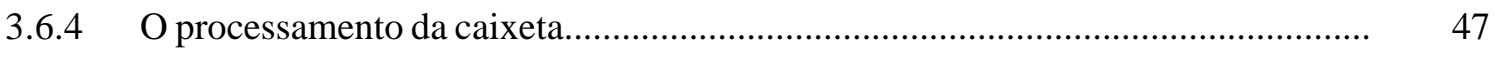

4 ECONOMIA DA EXPLORAÇÃO DA CAIXETA............................................ 54

4.1 Aspectos teóricos e metodológicos: uma revisão da literatura................................ 54

4.2 Análise Benefício - Custo............................................................................ 60

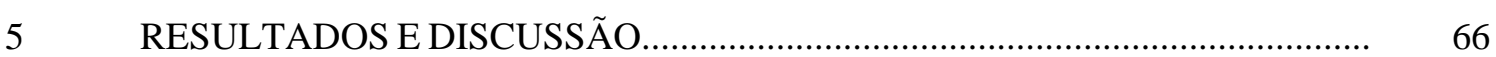




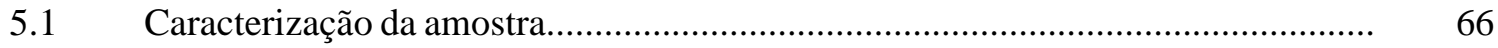

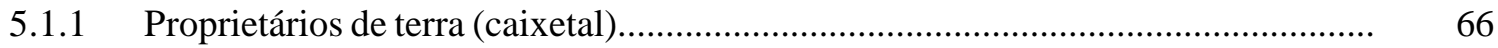

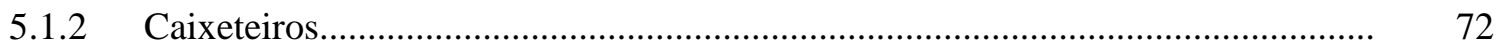

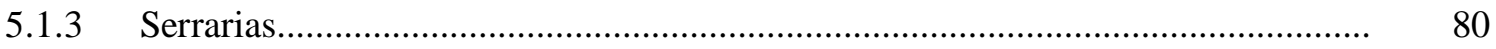

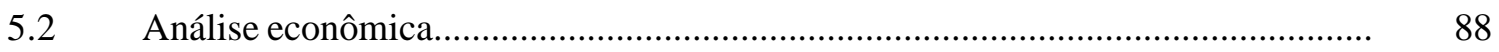

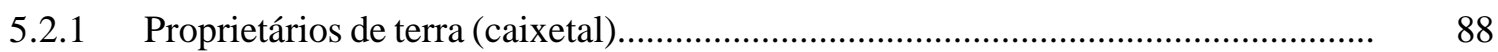

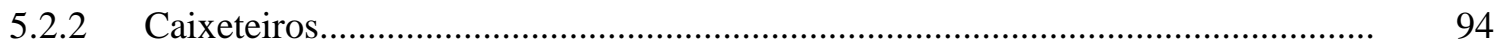

5.2.3 Estimativa da rentabilidade da bananicultura na região de estudo......................... 95

5.3 Ponto econômico ótimo de corte............................................................................ 101

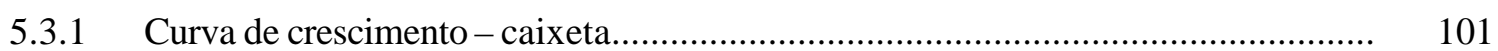

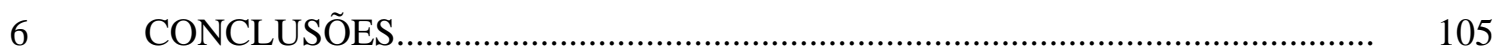

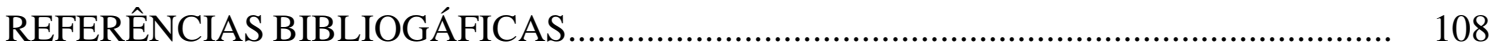




\section{LISTA DE FIGURAS}

Página

1 Formações florestais e ecossistemas associados da Mata Atlântica............................. 3

2 Cobertura vegetal original e remanescentes florestais da Mata Atlântica................... 4

3 Cobertura vegetal original e remanescentes florestais da Mata Atlântica do Estado de São Paulo......................................................................................................................... 5

$4 \quad$ Os ecossistemas naturais de caixeta e suas espécies mais frequentes........................ 21

$5 \quad$ Caixeteiro realizando a desbrota, um ano após o corte.............................................. 32

$6 \quad$ Fluxo de Produto (madeira e seus subprodutos)...................................................... 38

$7 \quad$ Caixeteiro realizando o corte da árvore..................................................................... 39

8 Resíduos não madeireiros (bromélias) da colheita da caixeta...................................... 41

$9 \quad$ Transporte braçal das toras ao "porto" ...................................................................... 42

10 Transporte por trilhos das toras ao "porto"................................................................ 43

11 Carregamento das toras no "porto" ................................................................................ 44

12 Fluxo de informação da cadeia agroindustrial da caixeta......................................... 46

13 Fluxo de Serviços na operação de extração e processamento da Caixeta para lápis.. 50

14 Fluxo de Serviços na operações de extração e processamento da Caixeta para

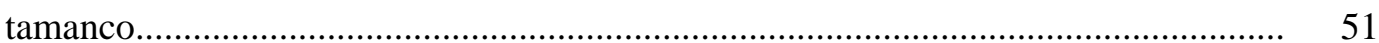

15 Fluxo de Serviços na operação de extração e processamento da Caixeta para

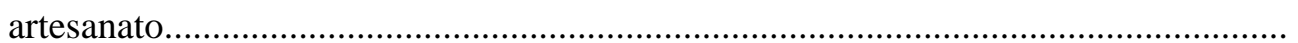

16 Resíduos madeireiros do processamento da caixeta (costaneiras, serragens e

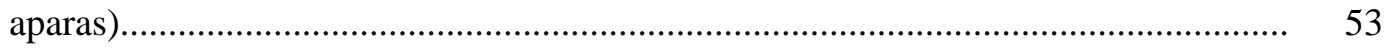

17 Curva Estimada de Crescimento Acumulado da Caixeta............................................ 103

18 Curva Estimada do Incremento Anual do Volume de madeira.................................. 103

19 Curva Estimada da Taxa de Crescimento Anual da Caixeta...................................... 104 


\section{LISTA DE TABELAS}

Página

1 Distribuição dos municípios do Vale do Ribeira, por faixa do índice de desenvolvimento humano (IDH), no período de $1996 .$.

2 Ocupação do solo nos municípios do Vale do Ribeira, por faixa do índice de desenvolvimento humano (IDH), no período de 1996, em hectares..............................

3 Principais lavouras dos municípios do Vale do Ribeira, por índice de desenvolvimento humano (IDH), no período de 1996, em hectares.

4 Áreas de ocorrência de caixeta na região sudeste do Estado de São Paulo, em hectares.

5 Número de propriedade por estrato de área total, em alqueires, na amostra. 66

6 Número de caixetais por estrato de área de caixetal, em alqueires, na amostra.

7 Distribuição das propriedades por atividade desenvolvida na amostra.

8 Distribuição das propriedades por estrato de número de extrações total e com plano de manejo

9 Motivos para a conversão do solo dos caixetais e número de ocorrências.

10 Distribuição da percepção dos entrevistados em relação à rentabilidade da atividade extrativista

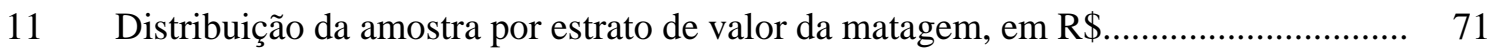

12 Distribuição da amostra por estrato de Idade.......................................................... 72

13 Distribuição da composição familiar dos caixeteiros na amostra................................ 72

14 Distribuição do grau de escolaridade dos caixeteiros na amostra............................... 73 
15 Distribuição das atividades exercidas pelos caixeteiros da amostra durante o ano.....

16 Motivos para a periodicidade na extração da caixeta e número de ocorrências...........

17 Número de ocorrência de relatos de problemas relativos à extração da caixeta na amostra.

18 Tipo de produto a que as toras se destinam........................................................... 77

19 Volume de caixeta processada pela serraria JP da Silva em 2001, em mst................ 82

20 Volume de caixeta processada pela serraria AJJ em 2001, em mst........................... 82

21 Volume de caixeta processada pela serraria ACAX em 2001, em mst...................... 83

22 Tipos de resíduos madeireros gerados no processamento primário da caixeta na produção de artesanato e tamanco pelas serrarias AJJ, JP da Silva e ACAX.............. 86

23 Motivos que causam a variação no preço da madeira em toras para as serrarias AJJ, ACAX e JP da Silva

24 Margem Bruta do manejo da caixeta para proprietários de terra, região do Vale do Ribeira-SP, em R \$ por mst e R \$ por ha. Para valor da matagem estimado em R \$ $20,00 / \mathrm{mst}$

25 Margem Bruta do manejo da caixeta para proprietários de terra, região do Vale do Ribeira-SP, em R \$ por mst e R \$ por ha. Para valor da matagem estimado em R\$ $25,00 / \mathrm{mst}$

26 Margem Bruta do manejo da caixeta para proprietários de terra que são caixeteiros, região do Vale do Ribeira-SP, em R\$ por mst e R\$ por ha.Aproveitamento: 20 mst por ha.

27 Margem Bruta do manejo da caixeta para proprietários de terra que são caixeteiros, região do Vale do Ribeira-SP, em R \$ por mst e R\$ por ha. Aproveitamento: 30 mst por ha......

28 Margem Bruta do manejo da caixeta para proprietários de terra que são caixeteiros, região do Vale do Ribeira-SP, em R \$ por mst e R\$ por ha. Aproveitamento: 40 mst por ha

29 Margem Bruta do manejo da caixeta para proprietários de terra que são caixeteiros, região do Vale do Ribeira-SP, em R \$ por mst e R\$ por ha. Aproveitamento: 60 mst por ha. 
30 Margem Bruta do manejo da caixeta para proprietários de terra que são caixeteiros, região do Vale do Ribeira-SP, em R \$ por mst e R\$ por ha. Aproveitamento: 110 mst por ha

31 Receitas e Despesas do manejo da caixeta para caixeteiros, região do Vale do Ribeira-SP, em R \$ por mst.

32 Cultura da Banana Nanica: Estimativas de Custos, Receitas e Fluxo Líquido ao longo de 20 anos*, na região do Vale do Ribeira-SP, em R $\$ /$ ha (alta produtividade)

33 Cultura da Banana Nanica: Estimativas do Valor Presente Líquido (VPL) e da Receita anual Equivalente (RAEq.) ao longo de 20 anos*, na região do Vale do Ribeira-SP, em R $\$ /$ ha (alta produtividade)......

34 Cultura da Banana Nanica: Estimativas de Custos, Receitas e Fluxo Líquido ao longo de 20 anos*, na região do Vale do Ribeira-SP, em R \$/ha (média produtividade)

35 Cultura da Banana Nanica: Estimativas do Valor Presente Líquido (VPL) e da Receita anual Equivalente (RAEq.) ao longo de 20 anos*, na região do Vale do Ribeira-SP, em ha (média produtividade).

36 Valor Presente Líquido (VPL) e Receita Anual Equivalente (RAEq.) do manejo da caixeta para proprietários de terra da região do Vale do Ribeira-SP, em R \$ por ha, para aproveitamento estimado de: $20 \mathrm{mst}$ por ha; $30 \mathrm{mst} \mathrm{ha}^{-1} ; 40 \mathrm{mst} \mathrm{ha}^{-1} ; 60 \mathrm{mst} \mathrm{ha}^{-1}$; e, $110 \mathrm{mst} \mathrm{ha}^{-1}$. Valor da matagem estimado em $\mathrm{R} \$ 20,00$ por mst.

37 Resultados das estimativas do modelo de regressão (Equação 10) do volume de caixeta em função do tempo 


\title{
ANÁLISE ECONÔMICA DO MANEJO DA CAIXETA - Tabebuia cassinoides (Lam.) DC NA REGIÃO DO VALE DO RIBEIRA-SP: UM ESTUDO DE CASO
}

\author{
Autora: ROBERTA CASTRO \\ Orientador: Prof. Dr. RICARDO SHIROTA
}

RESUMO

O presente trabalho teve como objetivo principal a análise da rentabilidade do manejo sustentável da caixeta - Tabebuia cassinoides (Lam.) DC para proprietários de terra da região do Vale do Ribeira-SP. A sua rentabilidade foi comparada com uma outra alternativa econômica de uso da terra na região, a bananicultura. $\mathrm{O}$ estudo estima a rentabilidade da caixeta para proprietários de terra que vendem a madeira "em pé" e para os que vendem a madeira em toras no "porto". Para isso, cinco cenários para o aproveitamento de madeira (20, 30, 40, 60 e $110 \mathrm{mst} / \mathrm{ha})$ foram considerados. Outro objetivo foi a análise da rentabilidade da atividade para agentes os caixeteiros que participam de seu processo de extração. A estrutura da cadeia produtiva (extração, processamento e comercialização) é analisada por meio do fluxo de produtos (e subprodutos) e do fluxo de informações da atividade na região de estudo. 
Em particular, o estudo estima a curva de crescimento da caixeta. Isto permite a análise do ponto ótimo de corte. Os objetivos foram atingidos por meio de pesquisa de campo realizada com proprietários de terra, caixeteiros e serrarias da região do Vale do RibeiraSP. Os resultados mostram que não existe uma estrutura organizada e formal de negociação entre proprietários de terra, caixeteiros e serrarias e/ou outros compradores. Fatores como baixa demanda e, portanto, baixo preço da madeira de caixeta, além de dificuldades burocráticas na realização do plano de manejo, contribuem para a inexistência de uma estrutura eficiente e formal no fluxo de informação da atividade. A rentabilidade da atividade estimada para caixeteiros varia entre 3,0 e 4,5 salários mínimos/mês, representando interessante fonte de renda e trabalho se comparadas às alternativas de trabalho existentes na região. Entretanto, para o proprietário da terra a comparação da rentabilidade da caixeta vis-à-vis à da banana mostra que a da banana é muito superior à da caixeta e, logo, conclui-se que os proprietários de caixetais não possuem incentivo econômico para a preservação dessas áreas. 


\title{
ECONOMIC ANALYSIS OF CAIXETA - Tabebuia cassinoides (Lam.) MANAGEMENT IN THE VALE DO RIBEIRA-SP REGION: A CASE STUDY
}

\author{
Autora: ROBERTA CASTRO \\ Orientador: Prof. Dr. RICARDO SHIROTA
}

\section{SUMMARY}

The profitability of sustainable management of Caixeta - Tabebuia cassinoides (Lam.) DC - for the landowners in the Vale do Ribeira region in the State of São Paulo, is the main objective of this study. Its profitability was compared to the production of banana which is an alternative for the land use in this region. The study also compares the returns to the landowers that sells Caixeta as a tree (unlogged) versus the ones that log themselves to sell it logged. Five cenarios for the yield were considered: 20, 30, 40, 60 and $110 \mathrm{mst} / \mathrm{ha}$. Another objetive was to estimate the profitability for the professional loggers (caixeteiros). Caixeta's production chain (logging, processing and trade) was analysed through production and information flowcharts. The study also estimates the growth curve for Caixeta's tree. This information is important to estimate its optimal logging age. The data used in the study were collected through interviews with landowners, caixeteiros and sawmill owners in the Vale do Ribeira region. The results show that the activity lacks a formal and organized production chain specially in terms 
of negotiation scheme between the market participants. The information does not seem to flow efficiently in the market as a consequence of low demand and price, besides the difficulties related to the process of elaboration and approval of Caixeta's management plan. The activity seems to be financially attractive to the caixeteiros that make between 3,0 and 4,5 minimum wages/month. It is an interesting source of income if compared to the job alternatives in the region. However, to the landowners, the revenue obtained from Caixeta is much smaller that from banana. Thus, the owners of land under Caixeta trees do not have economic incentives to preserve this natural ecosystem. 


\section{INTRODUÇÃO}

O presente estudo analisa a viabilidade econômica do manejo sustentável de um recurso biológico extrativo da Mata Atlântica, a caixeta -Tabebuia cassinoides (Lam.) DC, na região do Vale do Ribeira-SP. A análise estima a rentabilidade da exploração dessa espécie para dois agentes que participam das fases iniciais da sua cadeia produtiva (os proprietários de terra e os caixeteiros).

Historicamente, o homem tem extraído diversos recursos da natureza para atender às suas necessidades. Ele tem provocado várias transformações nos ecossistemas terrestres, com destaque às intervenções no ecossistema florestal, que ocorrem com maior grau de intensidade devido, principalmente, ao aumento das populações (Flores, 1993). A pressão demográfica aumenta as necessidades básicas de produção de alimento e por fontes de energia e, logo, promovem o crescimento das pressões sobre as formações florestais naturais (Flores, 1993; Agelsen et al., 1999).

Considerando que os países em desenvolvimento, em sua maioria, encontram-se nos trópicos e que as florestas tropicais abrangem 1.200 milhões de hectares (Lamprecht, 1990), estas são as regiões mais atingidas. Na década de 90, cerca de 11 milhões de hectares de florestas tropicais, anualmente, sofriam a conversão de suas terras para a agricultura, pecuária e outros usos (Gomes-Pompa \& Burley, 1991; Flores, 1993).

As florestas tropicais são ecossistemas que abrigam alta biodiversidade e hospedam cerca de dois terços do total de espécies do planeta (Almeida, 2000). O Brasil, com suas duas grandes florestas, Amazônica e Atlântica, destaca-se como um dos países possuidores da maior biodiversidade do mundo, com cerca de 357 milhões de hectares de florestas tropicais (representando $30 \%$ do total existente no planeta). Estima-se que 
$10 \%$ dos 1,4 milhões de organismos conhecidos pela ciência estão em território brasileiro (Almeida, 2000).

Além da redução da biodiversidade, as conseqüências dos desmatamentos incluem a erosão e perda de fertilidade dos solos, mudanças no regime e na qualidade dos recursos hídricos, podendo resultar em perdas para o meio ambiente (Flores, 1993; Agelsen et al., 1999). Assim, a diminuição da cobertura florestal afeta o potencial produtivo da agricultura, agravando a situação de países em estágios de desenvolvimento, como o Brasil, onde a produção agrícola possui relevante contribuição na geração da renda nacional.

As diferentes formações ${ }^{1}$ que compõem a Mata Atlântica abrangem uma área total de $1.100 .000 \mathrm{~km}^{2}$, distribuídos em quatro das cinco regiões geográficas brasileiras (Ministério do Meio Ambiente dos Recursos Hídricos e da Amazônia Legal, 1998) (Figura 1).

A Mata Atlântica e seus ecossistemas associados cobriam, originalmente, uma área de $1.290 .692,46 \mathrm{~km}^{2}$, que correspondia a cerca de $15 \%$ do território brasileiro, espalhados por 17 Estados (RS, SC, PR, SP, GO, MS, RJ, MG, ES, BA, AL, SE, PB, PE, RN, CE e PI). O processo de ocupação do Brasil causou drástica redução de sua cobertura vegetal original, hoje dispersa ao longo da costa brasileira e no interior das regiões Sul e Sudeste. Além disso, existem importantes fragmentos no sul dos estados de Goiás e Mato Grosso do Sul e no interior dos estados do Nordeste (Fundação SOS Mata Atlântica, 2002) (Figura 2).

\footnotetext{
${ }^{1}$ Florestas Ombrófilas Densas; Florestas Estacionais Semideciduais e Deciduais; Florestas Ombrófilas Mistas; Florestas Ombrófilas Abertas; florísticas associadas, como manguezais e restingas e ilhas litorâneas; os encraves de cerrados, campos, e campos de altitude compreendidos no interior das Florestas Ombrófilas; as matas de topo de morro e de encostas do Nordeste, como brejos e clãs, e as formações vegetais nativas da Ilha de Fernando de Noronha (Ministério do Meio Ambiente dos Recursos Hídricos e da Amazônia Legal, 1998).
} 


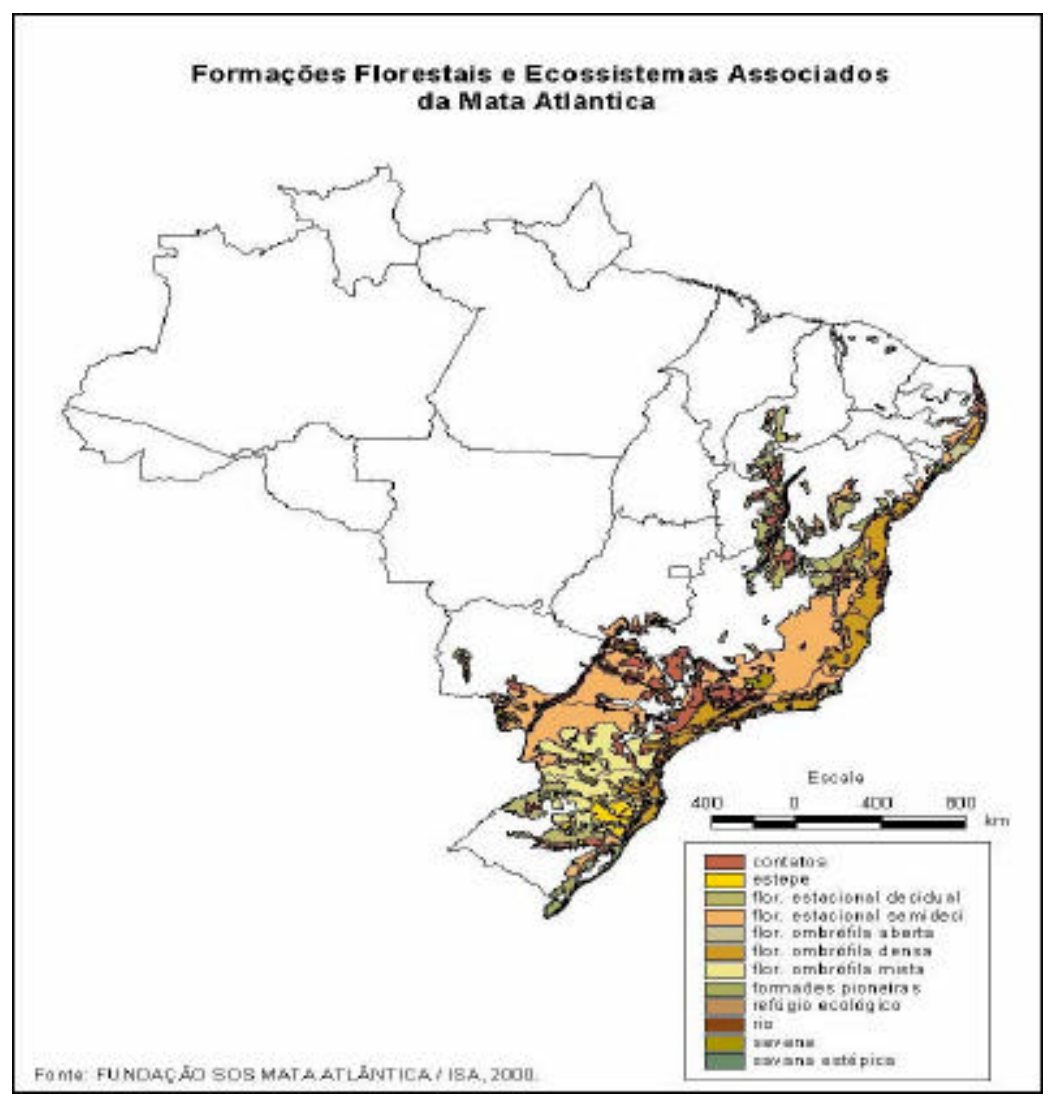

Figura 1 - Formações florestais e ecossistemas associados da Mata Atlântica.

A riqueza de espécies vegetais chega a cerca de 20.000, sendo a metade exclusiva da Mata Atlântica. Entretanto, atualmente, sua cobertura florestal está reduzida a 7\% da original. As áreas remanescentes não se distribuem uniformemente por todos os ecossistemas do bioma. A maior parte encontra-se em unidades de conservação ou sob pressão da atividade rural ou da expansão urbana (Ministério do Meio Ambiente dos Recursos Hídricos e da Amazônia Legal, 1998) (Figura 2).

A região da Mata Atlântica foi tradicionalmente a principal fonte de produtos agrícolas para populações litorâneas e hoje abriga os maiores pólos industriais e silviculturais do Brasil, além dos mais importantes aglomerados urbanos do país (Fundação SOS Mata Atlântica, 2002). Na Constituição Federal de 1988, ela foi incluída como Patrimônio Nacional. A Constituição ainda destaca a importância de sua 
conservação e preservação, já que abriga extensa diversidade biológica e cultural e, também, assegura a proteção do solo; dos sítios arqueológicos, turísticos e mananciais. Os mananciais fluviais da região são a garantia de abastecimento de água potável para mais de 100 milhões de pessoas, correspondendo a cerca de $60 \%$ da população brasileira (Ministério do Meio Ambiente dos Recursos Hídricos e da Amazônia Legal, 1998).

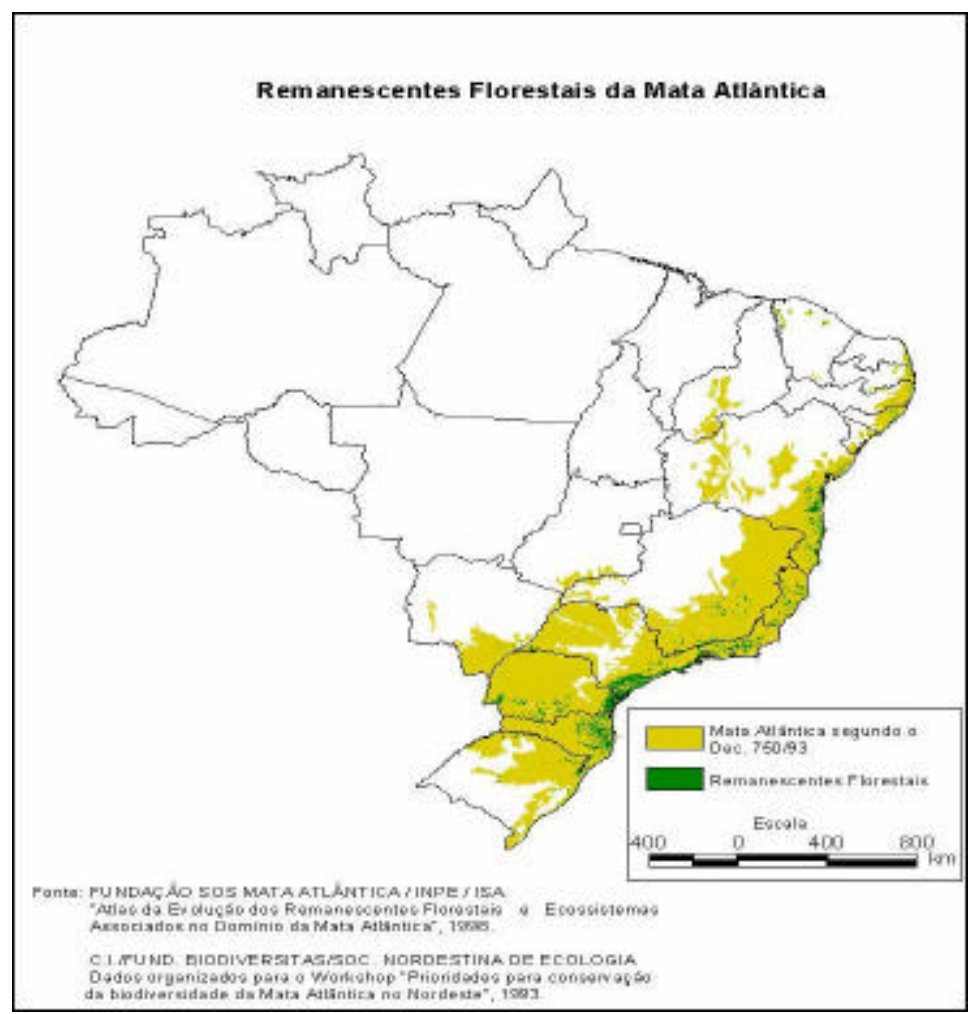

Figura 2 - Cobertura vegetal original e remanescentes florestais da Mata Atlântica.

O Estado de São Paulo abriga hoje 18\% da Mata Atlântica remanescente no Brasil. Ela concentra-se ao longo do litoral e encostas da Serra do Mar. No Vale do Ribeira $^{2}$, encontra-se a maior parte da cobertura florestal natural remanescente do Estado. São cerca de 800.000 hectares de floresta nativa que correspondem a $47 \%$ da área na região. Estas florestas estão distribuídas em propriedades particulares e unidades

${ }^{2} \mathrm{O}$ Vale do Ribeira está localizado na região sudeste do Estado. 
de conservação (parques estaduais, estações e reservas ecológicas, reservas indígenas e áreas de proteção ambiental) conferindo à região vocação florestal por excelência (Lepsch et al., 1990, Nolasco, 2000) (Figura 3).

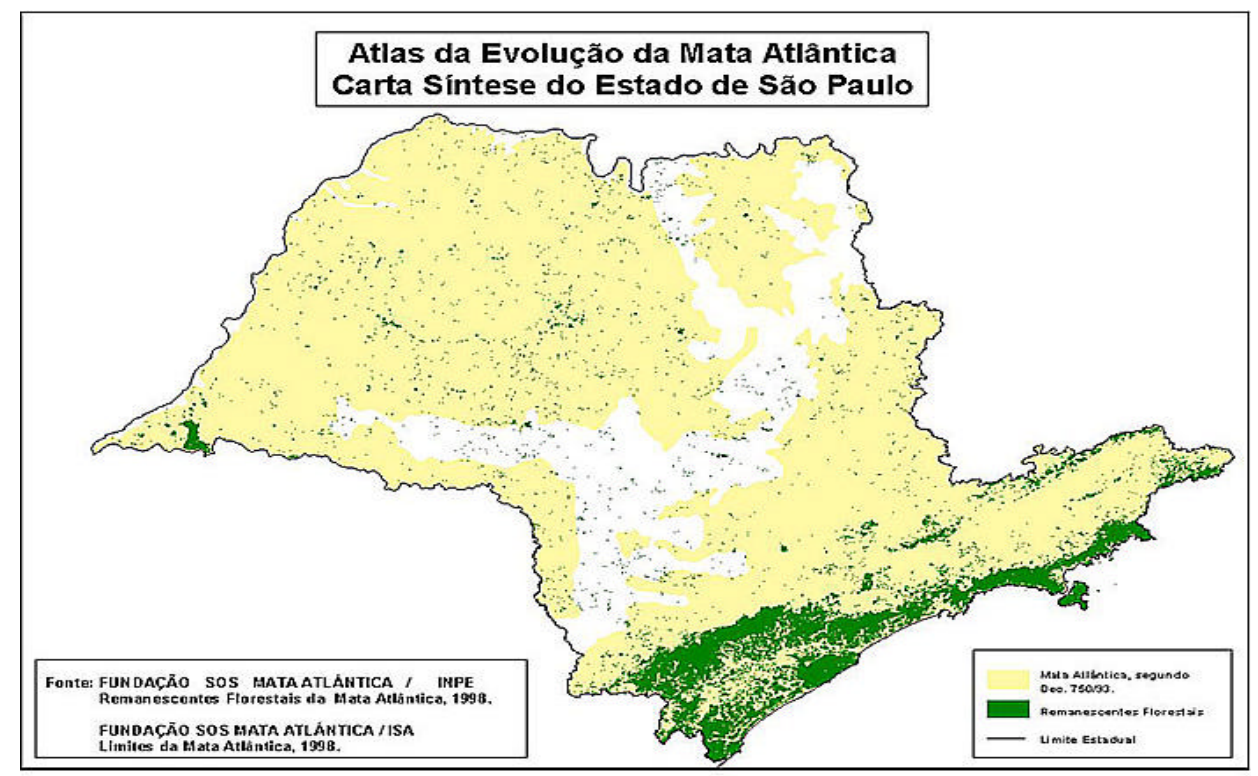

Figura 3 - Cobertura vegetal original e remanescentes florestais da Mata Atlântica do Estado de São Paulo.

No entanto, essas áreas estão sujeitas a forte pressão do processo de crescimento econômico e urbano, como no caso da expansão agropecuária (Silva, 2000). O desmatamento da Mata Atlântica tem o ritmo de um campo de futebol a cada quatro minutos. O monitoramento desse ecossistema realizado pela Fundação SOS Mata Atlântica em parceria com o Instituto Nacional de Pesquisas Espaciais (INPE) e o Instituto Socioambiental (ISA), mostra que entre 1990 e 1995, mais de meio milhão de hectares de florestas foram destruídos em nove estados nas regiões Sul, Sudeste e Centro-Oeste. Estas regiões concentram aproximadamente 90\% da Mata Atlântica remanescente no país (Fundação SOS Mata Atlântica, 2002). 
Em 1993, por meio do Decreto 750, foi definido legalmente o domínio da Mata Atlântica e a proteção aos remanescentes florestais e matas em regeneração. $\mathrm{O}$ Decreto 750, se transformado em lei complementar, poderia consolidar a proteção federal à Mata Atlântica. Enquanto isso não acontece, os Estados definem suas próprias regras para evitar os desmatamentos.

Este Decreto dispõe sobre o corte, a exploração e a supressão de vegetação primária ou nos estágios avançado e médio de regeneração da Mata Atlântica. $\mathrm{O}$ Art. $1^{\mathrm{o}}$ proibe o corte, a exploração e a supressão de vegetação primária ou nos estágios avançado e médio de regeneração. Excepcionalmente ${ }^{3}$, a supressão da vegetação primária ou em estágios de regeneração médio e avançado da vegetação poderá ser autorizada, mediante decisão motivada do órgão estadual competente, com anuência prévia do Instituto Brasileiro do Meio Ambiente e dos Recursos Naturais Renováveis (IBAMA) informando-se ao Conselho Nacional do Meio Ambiente (CONAMA).

O Art. $2^{\circ}$ dispõe sobre a exploração seletiva de determinadas espécies nativas nas áreas cobertas por vegetação primária ou nos estágios médio e avançado de regeneração, podendo ser efetuada desde que observados os seguintes requisitos:

I. Não promova a supressão de espécies distintas das autorizadas através de práticas de roçadas, bosqueamento e similares;

II. Elaboração de projetos, fundamentados, entre outros aspectos, em estudos prévios técnico-científicos de estoques e de garantia de capacidade de manutenção da espécie;

III. Estabelecimento de área e de retiradas máximas anuais; e,

IV. Prévia autorização do órgão estadual competente, de acordo com as diretrizes e critérios por ele estabelecidos.

Considerando a necessidade de se definir vegetação primária e secundária nos estágios pioneiro inicial, médio e avançado de regeneração de Mata Atlântica, em cumprimento ao disposto no artigo $6^{\circ}$ (Decreto 750/1993) e da Resolução CONAMA nº

\footnotetext{
${ }^{3}$ Quando necessária à execução de obras, planos, atividades ou projetos de utilidade pública ou interesse social, mediante aprovação de estudo e relatório de impacto ambiental.
} 
10/1993, e a fim de orientar os procedimentos de licenciamento de exploração da vegetação nativa no Estado de São Paulo, foi criada e elaborada a Resolução nº 1/1994. $\mathrm{Na}$ qual a caixeta é considerada espécie árborea em estágio médio de regeneração (Artigo $2^{\circ}$ ).

O Projeto de Lei $n^{\circ} 285 / 99$, visa assegurar a proteção dos remanescentes da Mata Atlântica. Nele a floresta é definida e classificada segundo distinção entre vegetação primária e secundária. A primeira, apresenta pouca alteração por intervenção humana ou já se encontra essencialmente recuperada. A secundária, é a vegetação resultante do processo de regeneração de áreas desmatadas ou degradadas. No caso da vegetação secundária, o texto identifica os estágios inicial, médio e avançado de regeneração.

São estabelecidas restrições e critérios para o corte, a supressão e a exploração da vegetação, tanto nas áreas rurais quanto urbanas, e cujo rigor vai decrescendo à medida que se caminha da vegetação primária em direção à vegetação secundária e os em estágio inicial de regeneração. Assim, enquanto se proíbe o corte, a supressão e a exploração da vegetação primária (exceto quando necessários à realização de obras, projetos ou atividades de utilidade pública), fica permitida a exploração seletiva de espécies da flora nativa em área de vegetação secundária em estágios médio e avançado de regeneração, desde que observadas as condições que o Projeto estabelece.

O corte e a supressão da vegetação ou o parcelamento do solo dos Ecossistemas Atlânticos previstos no Projeto de Lei no 285/99 (Art. 11º), ficam vedados, dentre outros casos, quando:

I. A vegetação:

a) Abrigar espécies da flora e da fauna silvestres ameaçadas de extinção, no território nacional ou em âmbito estadual, assim declaradas pela União ou pelos Estados, e a intervenção ou o parcelamento puserem em risco a sobrevivência dessas espécies;

b) Exercer a função de proteção de mananciais ou de prevenção e controle de erosão; 
c) Formar corredores entre remanescentes de vegetação primária ou secundária no estágio avançado de regeneração.

d) Proteger o entorno das unidades de conservação; ou,

e) Possuir excepcional valor paisagístico.

Novos empreendimentos que impliquem o corte ou supressão de vegetação dos Ecossistemas Atlânticos deverão ser implantados em áreas já substancialmente alteradas ou degradadas (Art. $12^{\circ}$ ). O corte e a supressão da vegetação primária dos Ecossistemas Atlânticos somente serão autorizados em caráter excepcional, quando necessários à realização de obras, projetos ou atividades de utilidade pública, pesquisas científicas e práticas preservacionistas (Art. $20^{\circ}$ ).

O corte, a supressão e a exploração da vegetação secundária no estágio avançado de regeneração (Art. $21^{\circ}$ ) dos Ecossistemas Atlânticos somente serão autorizados:

I. Em caráter excepcional, quando necessários à execução de obras, atividades ou projetos de utilidade pública, pesquisa científica e práticas preservacionistas; e,

II. Para a exploração seletiva de espécies da flora.

O corte, a supressão e a exploração da vegetação secundária em estágio médio de regeneração ${ }^{4}$ (Art. $23^{\circ}$ ) dos Ecossistemas Atlânticos somente serão autorizados:

I. Em caráter excepcional, quando necessários à execução de obras, atividades ou projetos de utilidade pública ou de interesse social, pesquisa científica e práticas preservacionistas;

II. Para a exploração seletiva de espécies da flora, conforme disposto no artigo 27 desta Lei; e,

III. Quando necessários ao pequeno produtor rural e populações tradicionais para o exercício de atividades agrosilvopastoris

\footnotetext{
${ }^{4}$ A caixeta está inserida nesta classificação.
} 
imprescindíveis à sua subsistência e de sua família, ressalvadas as áreas de preservação permanente e, quando for o caso, após averbação da reserva legal, nos termos da Lei ${ }^{\circ} 4.771 / 65$.

De acordo com o Art. $27^{\circ}$, é permitida a exploração seletiva de espécies da flora nativa em área de vegetação secundária nos estágios inicial, médio ou avançado de regeneração dos Ecossistemas Atlânticos, obedecidos, dentre outros, os seguintes pressupostos:

I. Exploração sustentável, de acordo com projeto técnica e cientificamente fundamentado;

II. Manutenção das condições necessárias para a reprodução e a sobrevivência das espécies nativas, inclusive a explorada;

III. Adoção de medidas para a minimização dos impactos ambientais, inclusive, se necessário, nas práticas de roçadas, bosqueamentos e infraestrutura.

IV. Vedação da exploração de espécies distintas das autorizadas;

V. Exploração não-prejudicial ao fluxo gênico e ao trânsito de animais da fauna silvestre entre fragmentos de vegetação primária ou secundária;

VI. Coerência entre o prazo previsto para a exploração e o ciclo biológico das espécies manejadas;

VII. Apresentação de relatórios anuais de execução pelo responsável técnico; e,

VIII. Realização de auditorias independentes, com periodicidade compatível com os prazos de exploração e a viabilidade econômica do projeto.

Outro aspecto desta lei a ser observado é em relação a propriedade rural que possuir cobertura florestal nativa primária ou nos estágios médio e avançado de regeneração de Ecossistema Attântico em percentual superior a 50\% de sua área total. Neste caso, a propriedade poderá ser declarada "Fazenda Florestal" (Art. $54^{\circ}$ ), por solicitação de seu proprietário, através de ato do órgão estadual competente, integrante do Sistema Nacional do Meio Ambiente 
(SISNAMA), ou supletivamente pelo IBAMA. Este proprietário poderá usufruir das seguintes regalias:

I. Prioridade nas ações de incentivos econômicos, tributário, creditício, fomento, estimulo fiscal, recebimento do Selo Verde dos Ecossistemas Atlânticos e outros benefícios, bem como suas solicitações legais junto aos órgãos competentes.

II. Para manutenção da categoria de Fazenda Florestal a propriedade deverá ser avaliada pelo menos a cada cinco anos por vistoria orientativa do órgão estadual competente, integrante do SISNAMA, ou através de auditoria independente que encaminhará a cada dois anos relatório ao órgão competente com análise da existência do percentual mínimo de cobertura florestal, observância da legislação ambiental e prática de atividades conservacionistas.

Desta forma, o manejo florestal representa uma importante alternativa econômica para a conservação da cobertura florestal. O manejo de recursos madeireiros e não madeireiros, em escala comercial, pode causar impactos ambientais. Porém, esses impactos poderão ser reduzidos com estudos que aprofundem o conhecimento científico sobre a espécie, tanto em relação aos aspectos ecológicos quanto aos comerciais, econômicos, sociais e políticos. Assim, as perdas ambientais poderão ser minimizadas havendo uma preservação dos benefícios econômicos, sociais e ambientais.

Neste sentido, o manejo sustentável de espécies nativas pode ser uma interessante alternativa para a manutenção e conservação da floresta. Muitas espécies nativas, com potencial para o manejo sustentável, além da caixeta estão sendo analisadas e avaliadas, nesta região, como a Samambaia Silvestre (Conte et al., 2000); plantas medicinais, como Espinheira-santa e Pariparoba (Di Stasi et al., 2000); Palmito Juçara (Sales et al., 2000); e recursos pesqueiros, como as ostras (Sales \& Maldonado, 2000). 


\section{$1.1 \quad$ Objetivos}

O principal objetivo do presente estudo é o de estimar a rentabilidade da atividade do manejo da caixeta para o dono do caixetal (proprietário da terra) e para o caixeteiro. Como objetivos secundários, destacam-se:

i) elaborar a estrutura da cadeia produtiva da caixeta, caracterizando os seus diversos segmentos;

ii) fazer uma comparação da rentabilidade econômica da caixeta visà-vis a cultura da banana; e,

iii) estimar a curva de crescimento da caixeta para determinar o seu ponto de corte ótimo. 


\section{O VALE DO RIBEIRA}

A região do Vale do Ribeira situa-se na parte sul-sudoeste do Estado de São Paulo, geograficamente circunscrita entre a Serra do Mar, do lado oeste do planalto da Região Metropolitana de São Paulo (RMSP), contornando o Litoral Sul até a divisa com o Paraná, e os contrafortes da Serra de Paranapiacaba, que divide o vale do planalto, a partir da região de Sorocaba. Seguindo-os pelas regiões de Itapetininga e Itapeva até o Alto Ribeira (Andrietta, 2002).

Por diferenças nos critérios de regionalização do Governo Estadual (administrativo) e do Instituto Brasileiro de Geografia e Estatística (IBGE) (geográfico), o número de municípios compreendidos na região varia conforme a fonte de dados. No que concerne à atividade agrícola, pela divisão do Estado efetuada pela Secretaria de Agricultura e Abastecimento (SAA), 15 municípios compõem a Região Agrícola de Registro $^{5}$ (Andrietta, 2002). Segundo o critério de bacia hidrográfica, a eles se acrescem outros sete municípios situados em regiões limítrofes (Gonçalves e Souza, 2001).

Essa região é a menos desenvolvida e mais pobre do Estado. Historicamente, o seu processo de crescimento e desenvolvimento econômico tem passado por diversos ciclos de produção, condicionados por diferentes fatores. Entre outros, as seguintes variáveis tiveram importantes papéis: ambientais (como relevo, clima e cobertura vegetal); socio-econômicos (desemprego e pobreza); analfabetismo; problemas fundiários; e o isolamento político regional (Vitae Civilis, 1995; Nolasco, 2000). Estes fatores restringiram o seu crescimento, limitando o desenvolvimento da economia regional, que tem a agricultura e a pecuária como principais atividades

5 Fazem parte da Região Agrícola de Registro os seguintes municípios: Barra do Turvo, Cajati, Cananéia, Eldorado, Iguape, Ilha Comprida, Iporanga, Itariri, Jacupiranga, Juquiá, Miracatu, Pariquera-Açu, Pedro de Toledo, Registro e Sete Barras (SAA, 2002). 
econômicas (Giordano, 1995).

Os ciclos econômicos que determinaram a ocupação humana no Vale do Ribeira tiveram duração e resultados variáveis. O município de Iguape teve dois ciclos econômicos importantes: o ciclo do ouro (1678-1763) e o ciclo do arroz (1770-1930).

Por volta de 1840 e até o início do século XX, esta região destacou-se no cenário econômico através das plantações de arroz. Porém, a perda de competitividade da sua produção em relação às outras regiões, provocou uma crise na economia do município (Rocha Filho, 1981).

Além disto, a abertura do Valo Grande, canal artificial construído com o objetivo de diminuir a distância a ser percorrida por barcos que transitavam pelo Ribeira de Iguape em direção à cidade, provocou o assoreamento do porto de Iguape, inviabilizando a navegação local. Também no início do século XX, a pesca artesanal, até então de subsistência, passou a representar a base econômica da região litorânea (Diegues et al., 1991).

Em decorrência desses ciclos, os moradores do Vale do Ribeira estabeleceram um sistema econômico diferenciado, dedicando-se ora à atividade principal, ora a outras atividades de subsistência, como a agricultura e o extrativismo vegetal e animal (Diegues et al., 1991; Nolasco, 2000).

A riqueza ambiental, histórica e cultural do Vale do Ribeira contrasta com a pobreza da população. Essa região esteve isolada do crescimento e desenvolvimento do Estado de São Paulo. Muitas das atividades econômicas que se estabeleceram com sucesso em outras regiões não trouxeram benefícios para região, que tinha como características poucas vias de acesso e um tipo de solo pouco propício para a agricultura. Isso fez com que seus municípios se mantivessem centrados basicamente na agricultura de subsistência e no extrativismo de recursos naturais, como a pesca, a coleta vegetal e a extração mineral (Secretaria de Estado do Meio Ambiente, 1992).

O isolamento geográfico e a miséria da população favoreceram, na década de 70, que integrantes de movimentos de contestação ao regime militar ali se refugiassem e treinassem grupos guerrilheiros (Secretaria de Estado do Meio Ambiente, 1992). Tal episódio chamou a atenção de autoridades governamentais que passaram a 
investir em infra-estrutura básica, buscando diminuir o isolamento econômico, social e político da região. Assim, medidas de incentivo à agricultura, à pesca e à ocupação imobiliária foram retomadas, incluindo a construção de estradas vicinais.

Um outro problema social da região está relacionado com a estrutura fundiária, ou seja, a questão da posse legítima e documentada da terra. Este problema surge devido à existência de inúmeras áreas das antigas províncias do Império que passaram, a partir de 1891, a constituir território dos Estados (as terras devolutas). Além de pessoas que ocupam as terras antes dos processos legais de regulamentação (posseiros) há, ainda, terras cuja documentação em cartório confere propriedade a mais de uma pessoa.

Atualmente, as atividades econômicas praticadas nos municípios do litoral Sul do Estado de São Paulo e suas fontes de renda são: a pesca (industrial, da manjuba e esportiva, do robalo), o cultivo da banana, chuchu e maracujá, e o turismo. Este último, intensificado a partir da década de 60, com o desenvolvimento e ampliação de rodovias estaduais e federais, incrementou a atuação do comércio imobiliário, provocando a ocupação de importantes áreas naturais. Nos municípios interioranos, a agricultura, com as monoculturas de banana e chá e a mineração destacam-se como atividades econômicas mais significativas. $\mathrm{O}$ extrativismo vegetal ocorre tanto em áreas litorâneas quanto interioranas, já que a cobertura vegetal estende-se das escarpas da Serra do Mar, até o litoral (Diegues et al., 1991; Secretaria do Meio Ambiente, 1989).

O Vale do Ribeira é uma das regiões mais carentes do Estado de São Paulo, apresentando indicadores sociais regionais relativamente baixos quando comparado com os de outras áreas do território nacional. Em seu conjunto, representa a região de menor índice de desenvolvimento humano (IDH) médio entre as 11 regiões administrativas do Estado de São Paulo. Com índice de 0,713, em 1996, situa-se no plano nacional entre o Pará $(0,703)$ e Sergipe $(0,731)$. No contexto internacional, o seu índice encontra-se entre a da Indonésia $(0,679)$ e a da África do Sul $(0,731)$ (Gonçalves e Souza, 2001). Isso não significa que a região não tenha se desenvolvido, mas sim que o ritmo desse processo não conduziu à redução das distâncias em relação às demais regiões paulistas, pois os índices regionais foram: 0,430 (1970), 0,620 (1980), 0,694 
(1991) e 0,713 (1996) (Gonçalves e Souza, 2001).

Por outro lado, no Vale do Ribeira encontram-se municípios cujos padrões são superiores aos verificados em muitos outros do Planalto Paulista. Registro, com IDH de 0,8358 está colocado em $177^{\circ}$ lugar entre os municípios paulistas. No entanto, à exceção de Registro, todos os demais municípios regionais encontram-se entre os mais pobres do Estado (Tabela 1).

Os municípios mais pobres têm seus IDHs puxados para baixo pelo indicador de renda. No tocante à esperança de vida ao nascer, o índice regional do Vale do Ribeira $(0,723)$ está próximo de outras regiões como a de São José do Rio Preto $(0,788)$. Na mensuração associada à educação não há também grande diferença entre o Vale do Ribeira $(0,842)$ em relação às demais. A diferença em relação à renda é relevante tanto no aspecto inter-regional como no contexto intra-regional. $\mathrm{O}$ componente renda varia de 0,2310, índice de Barra do Chapéu no Alto Ribeira, aos 0,9297, em Registro (Gonçalves e Souza, 2001).

O índice regional variou de 0,372, em 1970, para 0,772, em 1980, estabilizando-se em 0,769 nos anos oitenta. Apresentando queda para 0,547, em 1996. Isso mostra que o Vale do Ribeira perdeu renda nos anos noventa devido a declínios acentuados na economia regional. Entretanto, esse fenômeno não é característica apenas dos municípios com grande dependência econômica dos agronegócios, como Barra do Chapéu $(0,2310)$ e Barra do Turvo (0,2685). Ele ocorre também em outros que possuem importantes atrativos turísticos da região, como é o caso de Iporanga (0,2881) (Gonçalves e Souza, 2001).

Entre os municípios mais pobres, encontram-se muitos daqueles com menor percentual de reservas naturais, como Itaoca (17\%), Itapirapuã Paulista (19\%) e Barra do Chapéu (20\%) (Tabela 2). Mostrando que, mesmo tendo destruído a parcela preponderante de suas reservas naturais e incorporado essas terras às atividades econômicas, o fato não bastou para garantir um incremento substantivo da renda, ao contrário, parece ter contribuído para o aumento da pobreza (Gonçalves e Souza, 2001). 
Tabela 1. Distribuição dos municípios do Vale do Ribeira, por faixa do índice de desenvolvimento humano (IDH), no período de 1996.

\begin{tabular}{|c|c|c|c|c|c|}
\hline Município & IDH & $\begin{array}{r}\text { Expectativa } \\
\text { de vida }\end{array}$ & Educação & Renda & $\begin{array}{r}\text { Classificação } \\
\text { no Estado }\end{array}$ \\
\hline \multicolumn{6}{|l|}{ I - Mais de 0,7500} \\
\hline Registro & 0,8358 & 0,7256 & 0,8522 & 0,9297 & 177 \\
\hline \multicolumn{6}{|l|}{ II $-0,7000$ a 0,7499} \\
\hline Apiaí & 0,7055 & 0,6765 & 0,8187 & 0,6214 & 500 \\
\hline Iguape & 0,7225 & 0,7525 & 0,8105 & 0,6045 & 460 \\
\hline Jacupiranga & 0,7392 & 0,7754 & 0,7925 & 0,6498 & 410 \\
\hline Juquiá & 0,7187 & 0,7221 & 0,8088 & 0,6251 & 472 \\
\hline São Lourenço da Serra & 0,7237 & 0,7245 & 0,7966 & 0,6501 & 457 \\
\hline Sete Barras & 0,7009 & 0,7175 & 0,8035 & 0,5818 & 509 \\
\hline \multicolumn{6}{|l|}{ III - 0,6500 a 0,6999} \\
\hline Cajati & 0,6838 & 0,7617 & 0,8064 & 0,4844 & 554 \\
\hline Cananéia & 0,6758 & 0,6818 & 0,7974 & 0,5482 & 568 \\
\hline Eldorado & 0,6674 & 0,7130 & 0,7856 & 0,5046 & 577 \\
\hline Juquitiba & 0,6987 & 0,6330 & 0,7782 & 0,6850 & 513 \\
\hline Ilha Comprida & 0,6790 & 0,7262 & 0,8798 & 0,4311 & 565 \\
\hline Tapiraí & 0,6810 & 0,7528 & 0,7630 & 0,5271 & 563 \\
\hline Miracatu & 0,6820 & 0,6696 & 0,8012 & 0,5752 & 559 \\
\hline Pariquera-Açu & 0,6950 & 0,7332 & 0,8490 & 0,5029 & 527 \\
\hline \multicolumn{6}{|l|}{ IV- 0,6000 a 0,6499} \\
\hline Itaoca & 0,6403 & 0,7144 & 0,7830 & 0,4234 & 601 \\
\hline Itariri & 0,6437 & 0,6786 & 0,7864 & 0,4662 & 598 \\
\hline Pedro de Toledo & 0,6385 & 0,7408 & 0,7863 & 0,3884 & 603 \\
\hline \multicolumn{6}{|l|}{ V - Menor que 0,6000} \\
\hline Barra do Chapéu & 0,5692 & 0,7436 & 0,7330 & 0,2310 & 622 \\
\hline Iporanga & 0,5913 & 0,7118 & 0,7740 & 0,2881 & 617 \\
\hline Itapirapuã Paulista & 0,5769 & 0,7150 & 0,7723 & 0,2434 & 621 \\
\hline Barra do Turvo & 0,5476 & 0,6559 & 0,7184 & 0,2685 & 623 \\
\hline
\end{tabular}

Fonte: Gonçalves e Souza (2001)

A avaliação da participação relativa das pastagens no uso do solo, entre os municípios, encontra relações similares nos dois extremos do componente renda. $\mathrm{O}$ Município de Registro, que possui o maior índice de renda regional, com participação de $42 \%$, e o de Barra do Turvo, listado entre os mais pobres, apresenta $47 \%$ da área com pastagens (Gonçalves e Souza, 2001). A menor participação da pastagem também não mostrou correlação com o IDH. Iporanga, com 13\%, e Jacupiranga, com 12\%, estão colocadas em extremos de renda diferentes (Tabela 2). 
Tabela 2. Ocupação do solo nos municípios do Vale do Ribeira, por faixa do índice de desenvolvimento humano (IDH), no período de 1996, em hectares.

\begin{tabular}{lrrrrr}
\hline Município & Lavouras & Pastagens & Florestas & $\begin{array}{r}\text { Reservas } \\
\text { naturais }\end{array}$ & $\begin{array}{r}\text { Área } \\
\text { total }\end{array}$ \\
\hline I - Mais de 0,7500 & & & & & \\
$\quad$ Registro & 10.096 & 17.883 & 164 & 14.869 & 43.012 \\
II - 0,7000 a 0,7499 & & & & & \\
$\quad$ Apiaí & 3.057 & 20.500 & 3.455 & 20.045 & 47.057 \\
Iguape & 12.895 & 15.261 & 106 & 51.210 & 79.472 \\
Jacupiranga & 4.133 & 11.880 & 1.519 & 15.793 & 33.325 \\
$\quad$ Juquiá & 3.986 & 9.764 & 26 & 29.925 & 43.701 \\
$\quad$ São Lourenço da Serra & 129 & 54 & 144 & 283 & 610 \\
$\quad$ Sete Barras & 4.650 & 12.571 & 27 & 25.785 & 43.033 \\
III - 0,6500 a 0,6999 & & & & & \\
Cajati & 13.329 & 12.794 & 936 & 12.178 & 39.237 \\
Cananéia & 405 & 2.663 & 1 & 18.973 & 22.042 \\
Eldorado & 4.948 & 18.589 & 1.841 & 73.317 & 98.695 \\
Juquitiba & 121 & 593 & 1.919 & 3.142 & 5.775 \\
$\quad$ Ilha Comprida & 2 & 0 & 5 & 5 & 12 \\
Tapiraí & 1.527 & 1.858 & 326 & 12.183 & 15.894 \\
$\quad$ Miracatu & 5.069 & 5.587 & 58 & 21.949 & 32.663 \\
$\quad$ Pariquera-Açu & 3.296 & 6.764 & 134 & 9.433 & 19.627 \\
IV - 0,6000 a 0,6499 & & & & & \\
Itaoca & 401 & 8.723 & 138 & 1.892 & 11.154 \\
Itariri & 4.798 & 1.581 & 26 & 8.461 & 14.866 \\
$\quad$ Pedro de Toledo & 4.178 & 3.938 & 1.520 & 25.590 & 35.226 \\
V - Menor que 0,6000 & & & & & \\
$\quad$ Barra do Chapéu & 1.755 & 8.452 & 1.327 & 2.924 & 14.458 \\
Iporanga & 2.258 & 8.569 & 0 & 54.351 & 65.178 \\
Itapirapuã Paulista & 2.385 & 17.942 & 1.806 & 5.028 & 27.161 \\
Barra do Turvo & 3.483 & 37.995 & 0 & 39.901 & 81.379 \\
\hline & & & & &
\end{tabular}

Fonte: Gonçalves e Souza (2001)

Dentre as principais lavouras distribuídas no Vale do Ribeira, verifica-se cinco culturas regionais. A banana pode ser encontrada enquanto principal lavoura tanto entre municípios de alto IDH (Registro) como de baixo IDH (Itariri e Pedro de Toledo). O chá, restrito ao entorno de Registro se mostra decadente, não produziu índices favoráveis para Pariquera-Açu. O palmito de Iguape e Cajati segue o mesmo ritmo, assim como os cereais e as olerícolas (Gonçalves e Souza, 2001). A concentração da produção de cereais ocorre, como lavoura relevante, nos quatro municípios mais pobres (Tabela 3). A presença das lavouras como atividade importante não diferencia os 
municípios do Vale do Ribeira quanto ao seu desenvolvimento humano (Gonçalves e Souza, 2001).

Tabela 3. Principais lavouras dos municípios do Vale do Ribeira, por índice de desenvolvimento humano (IDH), no período de 1996, em hectares.

\begin{tabular}{|c|c|c|c|c|c|}
\hline Município & $\begin{array}{r}\text { Bana } \\
\text { na }\end{array}$ & Chá & Palmito & Cereais & Olerícolas \\
\hline \multicolumn{6}{|l|}{ I - Mais de 0,7500} \\
\hline Registro & 4.626 & 2.877 & 30 & 758 & 32 \\
\hline \multicolumn{6}{|l|}{ II - 0,7000 a 0,7499} \\
\hline Apiaí & 0 & 0 & 0 & 2.150 & 1.582 \\
\hline Iguape & 2.733 & 0 & 8.491 & 250 & 726 \\
\hline Jacupiranga & 3.524 & 0 & 78 & 260 & 2 \\
\hline Juquiá & 3.113 & 0 & 362 & 9 & 30 \\
\hline São Lourenço da Serra & 2 & 0 & 0 & 23 & 64 \\
\hline Sete Barras & 4.112 & 21 & 21 & 325 & 25 \\
\hline \multicolumn{6}{|l|}{ III - 0,6500 a 0,6999} \\
\hline Cajati & 5.158 & 0 & 7.918 & 96 & 31 \\
\hline Cananéia & 322 & 0 & 0 & 35 & 3 \\
\hline Eldorado & 4.004 & 0 & 37 & 402 & 55 \\
\hline Juquitiba & 0 & 0 & 0 & 47 & 119 \\
\hline Ilha Comprida & 0 & 0 & 1 & 0 & 0 \\
\hline Tapiraí & 458 & 398 & 50 & 166 & 298 \\
\hline Miracatu & 4.702 & 0 & 22 & 8 & 47 \\
\hline Pariquera-Açu & 276 & 1.020 & 6 & 56 & 16 \\
\hline \multicolumn{6}{|l|}{ IV - 0,6000 a 0,6499} \\
\hline Itaoca & 4 & 0 & 0 & 396 & 3 \\
\hline Itariri & 4.530 & 0 & 57 & 28 & 94 \\
\hline Pedro de Toledo & 3.719 & 0 & 32 & 142 & 12 \\
\hline \multicolumn{6}{|l|}{$\mathrm{V}$ - Menor que 0,6000} \\
\hline Barra do Chapéu & 0 & 0 & 0 & 1.648 & 163 \\
\hline Iporanga & 166 & 0 & 961 & 1.051 & 2 \\
\hline \multirow{2}{*}{$\begin{array}{l}\text { Itapirapuã Paulista } \\
\text { Barra do Turvo }\end{array}$} & 6 & 0 & 0 & 2.137 & 2 \\
\hline & 672 & 0 & 0 & 2.508 & 0 \\
\hline
\end{tabular}

Fonte: Gonçalves e Souza (2001)

Verifica-se que, na maioria dos municípios, prevalece a pecuária mista em quase todo o Vale do Ribeira. A especialização da pecuária, como mostram os indicadores regionais, é parecida com o perfil encontrado para as lavouras. As criações de bovinos de corte podem ser encontradas como atividades relevantes dentro da 
pecuária bovídea tanto em municípios de baixo IDH, como Barra do Turvo (38\%), como de alto IDH, como Registro (32\%) (Gonçalves e Souza, 2001). No caso dos bovinos de leite repete-se o fato. No geral, a presença da pecuária bovídea no Vale do Ribeira, nos moldes atuais, não altera sua dinâmica econômica e social.

O extrativismo vegetal é uma importante fonte de renda regional (Diegues et al.,1991; Viana et al $^{6}$., 1995; Nolasco, 2000). Porém, os dados disponíveis a respeito do valor econômico e social dessa atividade são restritos, e nenhuma análise foi feita no sentido de estimar o valor econômico e ambiental do manejo sustentável dos caixetais, no longo prazo, para as pessoas que estão diretamente envolvidas em seu processo produtivo (proprietários de caixetais, caixeteiros e serrarias), ressaltando a importância de estudos dessa natureza.

Trata-se de uma estratégia que visa assegurar a conservação do ambiente e da estrutura social dessas áreas que não proporcionam alto retorno econômico. Assim, elas sofrem uma pressão para a conversão de suas terras em favor da plantação de bananais ou outros produtos agrícolas e pastagem para búfalos, devido à característica alagada (Viana, op. cit.; Silva, 2000).

Assim, a identificação da importância relativa do manejo da caixeta em face da agricultura poderá contribuir para a eficiência e implantação de políticas públicas ambientais, contribuindo para o desenvolvimento e expansão da atividade na região.

\footnotetext{
${ }^{6}$ VIANA, V.M.; NOLASCO, A.M.; MARQUESINI, M. (Coord.). Projeto temático: "Manejo integrado e sustentável de florestas de caixeta no Vale do Ribeira-SP”. Piracicaba: USP, ESALQ/FAPESP, 1995. 105p. (Relatório final)
} 


\section{A CAIXETA - Tabebuia cassinoides (Lam.) DC.}

\subsection{Descrição botânica}

A caixeta é uma espécie arbórea que ocorre em depressões suaves e margens da planície litorânea ambas sujeitas a inundação (Inoue et al., 1984; Marquesini, 1994). A espécie ocorre naturalmente em áreas alagadas da planície litorânea na Mata Atlântica, do Estado de Pernambuco a Santa Catarina (Rizzini, 1971).

Os caixetais ou "ecossistemas naturais de caixeta" são formações florestais naturais, pioneiras de baixa diversidade e com predominância de caixeta, com densidade superior a 89\% (Nolasco, 2000). A espécie tem melhor desenvolvimento em áreas que apresentam variação da lâmina d'água durante o ano. Nas áreas permanentemente alagadas, o seu desenvolvimento é estagnado e, em áreas drenadas, a caixeta deixa de ser dominante devido à competição pelo estrato arbóreo com outras espécies (Marquesini, 1994; Marquesini \& Viana, 1995; Nolasco, 2000) (Figura 4).

Os caixetais apresentam alta diversidade de epífitas, como bromélias e orquídeas, lianas, musgos e líquens (Viana \& Nolasco, 1999). Os de segundo e terceiro corte apresentam alta biodiversidade e elevado nível de conservação dos solos e recursos hídricos (Viana, op. cit.).

A caixeta apresenta frequência irregular e descontínua, com ocorrência localizada, restrita aos locais brejosos próximos ao litoral, ocupando preferencialmente o sub-bosque de florestas primárias e secundárias úmidas sobre solos arenosos de drenagem deficiente (Carvalho, 1994; Inoue et al., 1984). Caracterizada como espécie de 
rápido crescimento e produtora de madeira leve com excelentes propriedades para a confecção de tamancos, instrumentos musicais, caixas finas, brinquedos, molduras para quadros, fabricação de lápis de alta qualidade, pequenos objetos e artesanatos (Rizzini, 1971; Inoue et al., 1984; Viana, op. cit.).

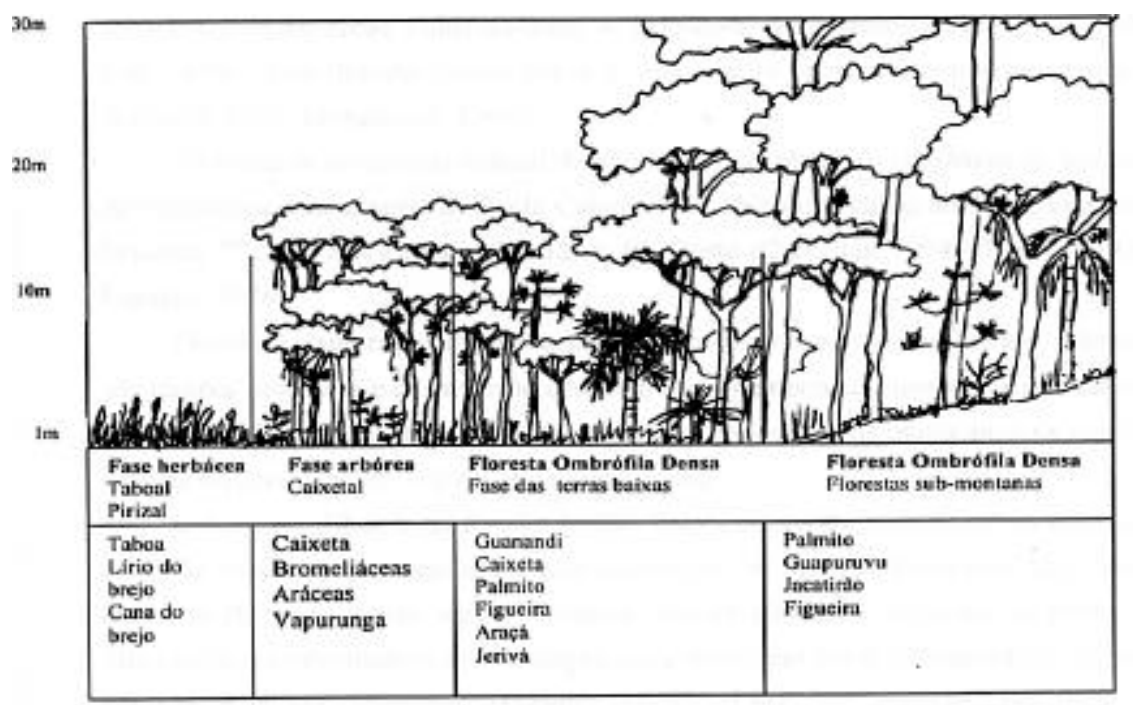

Figura 4 - Os ecossistemas naturais de caixeta e suas espécies mais frequentes. Fonte: Nolasco, A.M. (2000)

A exploração de caixeta é realizada, exclusivamente, em áreas de florestas naturais. A espécie possui algumas particularidades como grande potencial de regeneração da cepa após o corte e a capacidade de habitar áreas alagadiças. Estes fatores tornam seu manejo muito promissor, porém a maior parte da produção de caixeta sempre foi de caráter predatório, com florestas cortadas e abandonadas (Marquesini, 1994; Viana, op. cit.).

As florestas de caixeta ocorrem naturalmente em florestas paludosas da Mata Atlântica, em altitudes médias de 30 metros, na região litorânea das regiões Sudeste e Sul do País. Nesta região existe grande potencial de exploração da caixeta, 
concentrado principalmente no município de Iguape, Pariquera-Açú, Sete Barras e Registro (Diegues et al., 1991; Marquesini, 1994; Nolasco, 2000) (Tabela 4).

Tabela 4. Áreas de ocorrência de caixeta na região sudeste do Estado de São Paulo, em hectares.

\begin{tabular}{lrrr}
\hline Município/UF & No. de Caixetais & Área Estimada & Área em U.C. \\
\hline Iguape & 50 & 1170 & 445 \\
Ilha Comprida & 1 & 70 & 70 \\
Pariquera-Açu & 4 & 90 & 0 \\
Sete Barras & 4 & 185 & 0 \\
Cananéia & 3 & 135 & 65 \\
Registro & 2 & 45 & 0 \\
São Sebastião & 5 & 45 & 0 \\
Ubatuba & 1 & 15 & $15^{7}$ \\
TOTAL & 76 & 1990 & 785 \\
\hline
\end{tabular}

Fonte: Nolasco, A.M. (2000)

Mapeamento de caixetais realizado por Hamburguer \& Criscuolo (1995), no município de Iguape, identificou 909 caixetais e 51 áreas prováveis de ocorrência da espécie. A área total de caixetais foi estimada em 21 mil hectares.

Levantamento das florestas de caixeta existentes na região do Vale do Ribeira, litoral norte do Estado de São Paulo e na região do município de Paraty/RJ, realizado entre os anos de 1993 e 1997 identificou 76 caixetais com área total estimada em 3.184 ha (Marquesini et al., 2002 ${ }^{7}$ ). Deste total, cerca de 1.730 ha encontram-se em Unidades de Conservação (Estações Ecológicas de Cháuas e Juréia-Itatins, e Parques Estaduais da Ilha do Cardoso e de Pariquera-Abaixo).

Marquesini et al. (2002) mostra que 26\% desses caixetais encontram-se no estágio de sucessão médio-inicial; 52\% no estágio médio; e, o restante em estágios

\footnotetext{
${ }^{7}$ Trabalho não publicado.
} 
avançados. Estes possuem melhores condições de drenagem e, logo, têm características mais favoráveis à conversão do solo para o uso de culturas agrícolas e para pastagens (Silva, 2000).

No litoral norte de São Paulo, pode-se encontrar populações de caixeta nos municípios de São Sebastião e Ubatuba. Nestes dois municípios, as áreas de caixetais têm como característica o fato de encontrarem-se próximas ao mar. Esta característica faz com que estejam mais vulneráveis à ocupação humana devido a existência de condomínios e loteamentos de veraneio (Marquesini et al., 1996; Nolasco, 2000).

A conservação e preservação das áreas de caixetais são importantes por proporcionarem o desempenho de suas funções ecológicas (manutenção da biodiversidade, abrigo para fauna, conservação dos recursos hídricos e manutenção do potencial produtivo da floresta) e sócio-econômicas, como alternativa de trabalho e fonte de renda (Silva, 2000).

\subsection{Ciclo de exploração da caixeta}

A caixeta tem ciclo de vida em torno de 40 a 50 anos. O período estimado como ideal de aproveitamento comercial é de aproximadamente 25 a 30 anos (Nolasco, 2000). Árvores mais velhas começam a sofrer um processo de apodrecimento do seu lenho, do centro para a periferia e de baixo para cima, podendo resultar em tombamento por falta de sustentação (Marquesini \& Viana, 1994; Nolasco, 2000).

A espécie possui alta capacidade de se reproduzir vegetativamente por meio de brotações de cepas e raízes, além da propagação por sementes. O vigoroso crescimento dessas brotações e a capacidade de ser dominante do estrato arbóreo, fazem com que a espécie tenha grande potencialidade para o manejo sustentável, dispensando replantio ou adensamento (Nolasco, 2000; Silva, 200).

O período de floração varia com a localização geográfica do caixetal. Normalmente tem início em julho, estendendo-se até o verão. Os frutos amadurecem 
entre outubro e março (Nolasco, 2000). Outra produção de sementes, menos intensa, ocorre entre abril e maio. Assim, é comum a presença de árvores no interior dos caixetais florescendo e frutificando de maneira isolada durante, todo o ano (Nolasco, 2000).

A regeneração natural por meio de sementes é pouco freqüente devido ao fato de as sementes dificilmente atingirem o solo, em razão do abundante sub-bosque, da flutuação da lâmina d'água e da camada de matéria orgânica (galhos e folhas decompostas) (Silva, 2000). Entretanto, a regeneração por propagação vegetativa é excelente. A caixeta possui alta capacidade de emitir brotações nas cepas, galhos (que caem naturalmente ou são abandonados após a colheita) e, principalmente, por raízes (Silva, 2000; Nolasco, 2000).

Após o corte, entre dois a três meses, as cepas de caixeta começam a emitir uma grande quantidade de brotos com vigoroso crescimento (Silva, 2000). Caso não seja realizada uma seleção e desbaste, com o passar do tempo, os brotos passam a competir entre si crescendo mais lentamente (Silva, 2000). Assim, é recomendável que se faça desbrotamento do caixetal, um ano após o corte.

Estima-se que ocorra um crescimento de, aproximadamente, $1,68 \mathrm{~cm}$ (diâmetro do broto) por ano no caso de se deixar um broto por cepa. Supondo que o crescimento seja linear nos primeiros anos, seriam necessários 8,9 anos para os brotos atingirem o ponto de corte de 15,0 cm de diâmetro. Por outro lado, deixando dois brotos por cepa, o crescimento médio anual cai para $1,10 \mathrm{~cm} /$ ano. Nesse caso, o mesmo diâmetro $(15 \mathrm{~cm})$ seria atingido em cerca de 13,6 anos. É interessante observar que esta diferença no ciclo de corte pode ser compensada com um volume de madeira maior, já que a produção seria duplicada. Se a taxa de crescimento em diâmetro for contínua somente até $10 \mathrm{~cm}$ de diâmetro e, posteriormente, o crescimento assumir o comportamento encontrado para árvores adultas nunca cortadas que possuem diâmetro entre 10 e $25 \mathrm{~cm}$ (média de 0,44 cm por ano), seriam necessários, para as cepas com um broto, 17 anos para atingir o ponto de colheita (Silva, 2000). 


\subsection{Usos econômicos}

A caixeta é conhecida como madeira de boa trabalhabilidade, que permite bom acabamento de superfície e boa aparência. É considerada madeira perecível, mas de alta permeabilidade, o que facilita sua preservação. Leveza, cor e estabilidade, qualidades importantes da caixeta, são características que permitem a produção de lápis sextavados (tipo de lápis especial para desenho) e lápis cosméticos, que exigem excelente acabamento e facilidade no apontar, devido à textura da mina (Diegues et al., 1991). Ela é utilizada em produtos como tamancos ou saltos para calçados, instrumentos musicais (violão), cabides, móveis, brinquedos e artesanatos. Sua madeira possui ótima estabilidade dimensional, não racha durante a secagem e aceita acabamento (Lorenzi, 1992; Carvalho, 1984). Na fabricação de lápis é considerada a segunda melhor madeira do mundo ${ }^{8}$.

O mercado para a madeira de caixeta encontra-se fragmentado, não há um padrão ou estrutura fixa de como a caixeta se apresenta ao mercado, ou seja, de como tem sido comercializada. Essa restrição se deve, em grande parte, a proibição de sua colheita nos anos de 1989 a 1992, pela Portaria n. 218 do Instituto Brasileiro do Meio Ambiente e dos Recursos Naturais Renováveis (IBAMA), que fez com que a caixeta fosse substituída por outras espécies de madeira. Isto ocorreu, principalmente, em relação à produção de lápis, que foi (até a década de 80) o maior mercado para a caixeta.

Um outro fato que tem dificultado a volta da caixeta ao mercado foi a redução do seu preço nos últimos anos. Existe, atualmente uma competição com espécies vindas de reflorestamentos (como pinus) e da exploração predatória na Amazônia Brasileira (Viana et al., 1996). Os problemas da caixeta são os seus altos custos de extração e baixo rendimento devido às características da espécie, que se encontra em regiões alagadas e de difícil acesso e, algumas vezes, com o tronco tortuoso.

\footnotetext{
${ }^{8}$ A primeira, o cedro americano Calocedrus decurrens (Torry) Florin (Ramos, 1994).
} 
Segundo Viana op. cit. para o mercado de lápis do "tipo superior”, pincéis e tamancos, a caixeta é considerada madeira excepcional, podendo recuperar seu espaço no mercado desde que sua produção possa ser garantida no longo prazo, ou seja, seu manejo deve ocorrer de forma sustentável, com viabilidade econômica e de forma compatível com os estoques disponíveis.

\subsection{Histórico da exploração da caixeta}

A extração da caixeta, na região do Vale do Ribeira, iniciou-se por volta de 1937 (Diegues et al., 1991). Nesta época, a caixeta extraída na região era destinada a produção de tamancos, instrumentos musicais, brinquedos, e cabos de pincel. Era também utilizada, em pequena escala, na confecção de próteses de braços e pernas.

Na década de 50, a caixeta passou a ser utilizada na fabricação de lápis em substituição ao cedro americano - Libocedrus decurrens, que teve seu uso limitado devido aos altos impostos de importação praticados após a Segunda Guerra Mundial (Ramos, 1994). Nas décadas de 50 e 60, a caixeta foi a única madeira usada na fabricação de lápis no Brasil.

No início dos anos 70, teve seu uso substituído pelo pinus devido ao crescimento da demanda interna e externa por lápis, da dificuldade de se obter incrementos na colheita da caixeta e da facilidade na aquisição de madeira de reflorestamentos, como o pinus (Diegues et al., 1991; Marquesini, 1994; Nolasco, 2000).

A instalação de serraria especializadas na caixeta teve início em fins da década de 50. Na década de 80, em função do aumento da demanda interna e externa por lápis, cinco serrarias iniciaram suas atividades (Diegues et al., 1991).

Essas serrarias de caixeta, instaladas na região do Vale do Ribeira, produziam tabuinhas, destinadas à fabricação de lápis de duas indústrias, a Faber Castell e a Labra. Até os anos 1985/86 as serrarias não encontravam problemas quanto ao fornecimento de matéria-prima, pois havia certa facilidade em obter guia de autorização para desmatamento junto ao Departamento de Proteção aos Recursos Naturais(DEPRN). 
A caixeta era considerada como "lenha" e não como essência florestal de valor econômico (Diegues et al., 1991).

Até o final da década de 80 , a Faber-Castell era a única indústria fornecedora de lápis no mercado Latino-Americano, exportando a sua produção para 61 países. A maior parte de lápis "tipo médio" era feito de Pinus caribaea var. hondurensis (Diegues et al., 1991). Porém, devido à concorrência chinesa, que produz lápis do "tipo inferior" e de menor qualidade, desde essa época a Faber-Castell tem perdido mercado interno e externo, deixando de ocupar uma posição de destaque. O lápis produzido com caixeta é do "tipo superior" com alta qualidade, o que faz com que seja usado na industrialização de lápis especiais.

A caixeta teve seu mercado interno de tabuinhas para lápis reduzido, especialmente, devido ao fechamento, em 1988, da Labra - Indústria Brasileira de Lápis S/A. e da redução no consumo de tabuinhas pela A. W. Faber-Castell ${ }^{9}$. Nesta época, dez serrarias operavam na região do Vale do Ribeira-SP e no Estado do Paraná (Diegues et al., 1991). Nolasco (2000), em 1997, encontrou apenas duas destas serrarias, de processamento primário de caixeta, que não tinham cessado suas atividades.

No final da década de 80 a população, envolvida com a colheita e processamento da caixeta em Iguape-SP, organizou-se na "Associação de Reposição Florestal da Mata Atlântica-Iguape Refloresta", conhecida como Associação dos Caixeteiros (ACAX). Ela foi fundada em 1988 por donos e empregados de pequenas serrarias especializadas no processamento da caixeta para lápis. Nesta época, estas pessoas encontravam-se numa situação de dependência econômica de um único cliente (Faber Castell) e de fortes e crescentes pressões de ambientalistas sobre todas as atividades que implicavam no uso dos recursos florestais da Mata Atlântica (PROTER, 2001).

A partir de 1989, o Decreto Federal n. 99.547 proibiu a exploração de espécies nativas na Mata Atlântica, fazendo com que a atividade nos caixetais fosse interrompida. Essa ação trouxe uma série de problemas sociais, como o desemprego de

\footnotetext{
${ }^{9}$ A Faber-Castell cessou sua produção de lápis cosméticos, produzidos com caixeta, em 30/09/2000. Esta produção representava $1 \%$ de sua produção total, cerca de 10 mil lápis de caixeta/mês. A caixeta foi substituída pelo álamo da Argentina, madeira oriunda de reflorestamento (Mambo, proprietário da Serraria “O Casqueiro", Paranaguá-PR).
} 
cerca de 250 famílias que tinham na atividade extrativista sua principal fonte de renda (Diegues et al., 1991; Viana, op. cit.; 1995; Nolasco, 2000). Em 1992, a Resolução n. 11/92 da Secretaria do Estado do Meio Ambiente do Estado de São Paulo (SMA/SP) e o Decreto Federal n. 750/93 regulamentaram a exploração sustentada de caixeta (Marquesini et al.,1998; Nolasco, 2000). Em 1994, o Estado do Paraná decidiu, também, regulamentar o manejo da caixeta (Viana op. cit.).

Em 1995, no município de Iguape, foi instalada uma serraria da Associação dos Jovens da Juréia (AJJ), resultado de um projeto para geração de empregos para ex-moradores da Estação Ecológica Juréia-Itatins, que perderam suas fontes de renda após a criação do parque. Em 1996, teve início a instalação da serraria comunitária da Associação dos Caixeteiros de Iguape (ACAX) (Nolasco, 2000).

\subsection{Situação atual}

A preservação das áreas de caixetais é garantida pelo Código Florestal. O Decreto Federal n. 750/93, dispõe sobre o corte, a exploração e a supressão da vegetação primária ou nos estágios avançado e médio de regeneração da Mata Atlântica, e limita o aproveitamento dos recursos naturais aos espaços externos às unidades de conservação obedecidas as restrições impostas pelo Código Florestal.

Em 1991, a Secretaria do Meio Ambiente de São Paulo (SMA/SP) instituiu as normas para a elaboração de Planos de Manejo visando a exploração da caixeta no Estado. Esta iniciativa chegou ao grau mais elevado na Resolução SMA11/92, que estabelece as regras para a colheita da caixeta no Estado sob "regime de rendimento auto-sustentado", dando ênfase a garantia da produção volumétrica da floresta através da exigência da apresentação de uma plano de manejo, que deve conter os seguintes aspectos: 
i) inventário florestal da espécie com informações qualitativas e quantitativas (volume de madeira a ser colhida com diâmetro maior que $15 \mathrm{~cm}$, dominância e distribuição diamétrica);

ii) marcação das árvores porta-sementes (pelo menos 15 árvores/ha);

iii) croqui da área do caixetal;

iv) planta planialtimétrica da propriedade, contendo a delimitação das áreas de preservação permanente, Reserva Legal e da área a ser manejada;

v) localização das rotas de extração da madeira; a divisão em talhões, com colheita anual de uma área máxima $1 / 12$ da área total, considerando-se o ciclo de corte como sendo de 12 anos, com exceção das propriedades com caixetais pequenos, onde seja inviável o sistema de colheita por talhadia; e,

vi) cronograma de colheita e das práticas silviculturais e o compromisso de fazer a desbrota da área, 12 meses após o corte.

O DEPRN da Secretaria do Meio Ambiente de São Paulo (SMA/SP) é responsável pelo licenciamento e fiscalização dos planos de manejo de caixeta no Estado. As guias de transporte para produtos florestais são emitidas pelo Instituto Brasileiro do Meio Ambiente e dos Recursos Naturais Renováveis (IBAMA) mediante autorização de corte emitida pelo DEPRN (Silva, 2000; Nolasco, 2000).

Mesmo com a regulamentação do manejo da caixeta, a resolução SMA11/92 não se baseou em informações científicas sobre a caixeta visto que elas praticamente não existiam (Silva, 2000). Os critérios foram apoiados em informações obtidas em levantamento realizado com enfoque nos conhecimentos tradicionais sobre a espécie, em critérios de bom manejo para florestas tropicais e nas poucas informações científicas existentes sobre a espécie (Nolasco, 2000).

A aprovação do plano de manejo segue cinco procedimentos. Na primeira fase, o proprietário de terra (caixetal) consulta um engenheiro ou técnico florestal para dar início ao levantamento da área existente e que poderá ser manejada em regime de rendimento auto-sustentado. 
Na segunda fase é feito o levantamento da documentação necessária para apresentação da solicitação do plano junto ao DEPRN. São exigidos:

i) escritura do terreno ou o Certificado de Cadastro de Imóvel Rural (CCIR) fornecido pelo Instituto Nacional de Colonização e Reforma Agrária (INCRA) (no caso de posse);

ii) último imposto pago (ITR);

iii) planta da propriedade em escala 1/10.000 ou a cópia da carta 1/50.000 do Instituto Brasileiro de Geografia e Estatística (IBGE) aumentada;

iv) projeto de manejo assinado por engenheiro ou técnico florestal; e,

v) certidão negativa do imóvel.

Na terceira fase o DEPRN analisa a documentação e realiza a vistoria de campo para avaliação e conferência das informações do engenheiro ou técnico florestal. Na quarta fase o DEPRN irá emitir a autorização de corte da floresta, dando ao proprietário a permissão de extração da madeira. Finalmente, a quinta fase é a vistoria de campo, que fiscaliza o cumprimento do plano de manejo autorizado.

Durante a década de 90, diversas pesquisas científicas foram desenvolvidas nas seguintes áreas:

i) ecologia, caracterização de ecossistemas;

ii) regeneração natural e hidrologia;

iii) genética, caracterização da variabilidade genética entre florestas manejadas e não manejadas;

iv) manejo, inventário florestal;

v) práticas silviculturais pré-colheita, colheita e pós-coheita;

vi) aproveitamento e identificação das etapas geradoras de resíduos, no campo e no beneficiamento; 
vii) aproveitamento, no campo, de produtos não madeireiros e minimização de resíduos madeireiros através de seu melhor aproveitamento no processamento; e,

viii) desenvolvimento de novos produtos que utilizem resíduos madeireiros.

Essas pesquisas envolvem o "Projeto Caixeta", iniciado em 1992, e o projeto "Manejo Integrado e Sustentável de Florestas de Caixeta no Vale do RibeiraSP", iniciado em 1995. O "Projeto Caixeta" foi um programa de pesquisa financiado pela Fundação Ford e desenvolvido pela ESALQ/USP em parceria com o Núcleo de Apoio à Pesquisa sobre Populações Humanas e Áreas Úmidas Brasileiras (NAPAUB/USP), Associação dos Caixeteiros, União dos Moradores da Estação Ecológica Juréia-Itatins, Rede Brasileira Agroflorestal (REBRAF) e Programa da Terra (PROTER), com o objetivo de gerar informações e propor ações para conservar a biodiversidade e melhorar a qualidade de vida das populações locais (Nolasco, 2000).

O projeto "Manejo Integrado e Sustentável de Florestas de Caixeta no Vale do Ribeira-SP”, foi desenvolvido pelo departamento de Ciências Florestais ESALQ/USP e financiado pela FAPESP. Em 1998, teve início o projeto "Populações Tradicionais, Manejo Florestal e Cidadania”, financiado pela Fundação Ford, desenvolvido pela ESALQ/USP em parceria com o PROTER. Atualmente, encontra-se, em sua segunda fase na qual uma das preocupações de estudo é a análise ecológica e ambiental da certificação da caixeta.

A partir das informações geradas pelas pesquisas, associadas ao conhecimento acumulado pelos caixeteiros sobre a caixeta e seu ambiente, foi proposto um sistema de manejo que atendesse as exigências legais, que garantisse a sustentabilidade da floresta e a manutenção dos benefícios sócio-ambientais dos caixetais. O sistema de manejo aprimorado foi dividido em três etapas: pré-colheita, colheita e pós-colheita (Silva, 2000).

$\mathrm{Na}$ etapa de pré-colheita é realizado o levantamento do potencial produtivo da área e o planejamento das atividades de mapeamento, inventário florestal, corte de cipós e o planejamento da colheita e do escoamento da produção. A etapa da 
colheita tem como objetivos: reduzir o impacto sobre o caixetal; melhorar o aproveitamento do recurso madeireiro; promover o uso múltiplo da floresta; e, melhorar as condições de segurança e trabalho dos caixeteiros. As práticas pós-colheita dão ênfase ao melhoramento da produtividade da floresta, como a redução do ciclo de colheita. Devido à alta capacidade de rebrota da caixeta, uma das principais práticas para garantir a sustentabilidade da produção é a aplicação da prática de desbrota (Silva, 2000) (Figura $5)$.

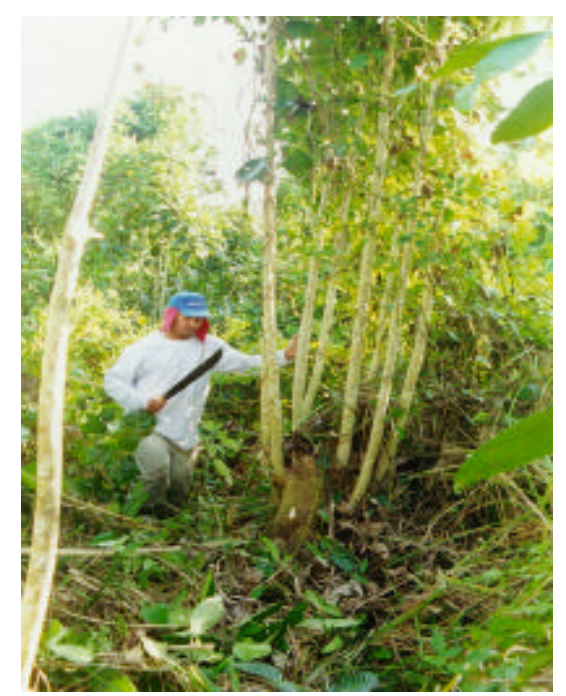

Figura 5 - Caixeteiro realizando a desbrota, um ano após o corte.

Pesquisa de mercado, para produtos ecológicos, realizada pelo Instituto de Manejo e Certificação Agrícola e Florestal (IMAFLORA), nos anos de 1996 e 1997, teve como enfoque a análise da demanda existente e, potencial, para a madeira de caixeta e epífitas. Neste estudo foram estudados os mercados das cidades de São Paulo, Curitiba, da região de Campinas e Piracicaba; e dos países Alemanha e Holanda. Foram selecionados sete produtos que utilizam a madeira de caixeta como matéria-prima (artesanato, caixas para embalagem, tampas para perfume, tabuinhas, próteses, desempenadeiras e brinquedos educativos), dois para os resíduos não madeireiros da 
colheita (epífitas) e um para os resíduos madeireiros do processamento primário (vasos e caxepôs feitos de costaneiras).

O mercado para artesanato demonstrou-se viável, foi verificada a existência de uma grande demanda por esse produto nas cidades de São Paulo e Rio de Janeiro. A vantagem em usar a madeira de caixeta para a produção de objetos de artesanato é que no processamento primário das toras, $65,40 \%$ da madeira é aproveitada. Além disso, os resíduos madeireiros podem ser aproveitados para a produção de pequenas peças.

Outro mercado estudado foi o de caixas para embalagem de produtos de alto valor, como caixas sofisticadas de lápis e produtos cosméticos. Os compradores potenciais seriam as indústrias $\mathrm{O}$ Boticário (Curitiba-PR) e a Cumberland Co. (Inglaterra). No entanto, para que esse mercado se torne viável é necessária a certificação da madeira e a verificação da possibilidade de extração e processamento em grande escala. Um outro mercado analisado e que encontra-se limitado por estes mesmos fatores é o de tampas para perfume.

O mercado de tabuinhas para lápis pode ser viável, desde que o padrão de qualidade exigido por clientes estrangeiros seja atingido. Para isso, é preciso investimento em materiais e equipamentos que aumentem a qualidade da madeira processada, como secagem e impregnação. O desafio deste mercado é a competição da madeira da caixeta com outras espécies, principalmente, a gmelina e o marupá, que possuem características muito semelhantes às da caixeta. Outro desafio relevante é o fato de o padrão internacional exigir tabuinhas acima de 7 e 8 "plys"10. Para a caixeta esse padrão torna seu rendimento baixo, podendo causar aumentos nos custos de extração e beneficiamento devido a características do diâmetro (largura e tortuosidade) (Nolasco ${ }^{11}$ ).

O mercado para próteses é pouco viável, pois os consumidores potenciais são entidades públicas, que para efetuarem suas compras têm que passar por extensos processos de licitação, com grande burocracia, o que dificulta as negociações. $O$

\footnotetext{
${ }^{10}$ Ply é a unidade de medida utilizada pelas indústrias de lápis que determina o número de lápis obtidos com duas tabuinhas de dimensões semelhantes.

${ }^{11}$ Informacões obtidas em observações escritas feita no trabalho apresentado em seminário, em out/2001.
} 
mercado consumidor deste tipo de produto encontra-se reduzido devido a substituição da madeira por materiais sintéticos.

Dois outros mercados que se demonstraram interessantes foi o de desempenadeiras, instrumento utilizado por pedreiros para alisar a massa de concreto, e o de brinquedos educativos. Testes de mercado feitos para esses produtos mostraram que os consumidores consideraram o material feito com caixeta de excelente qualidade (IMAFLORA, 1996).

Assim, a possibilidade de certificação da madeira de caixeta é, atualmente, a melhor alternativa para a ampliação e o fortalecimento de sua demanda nos mercados interno e externo. Para isso, o sistema de produção de caixeta deverá apresentar uma perspectiva favorável à certificação.

Várias razões garantem um manejo promissor para a caixeta, tais como: rebrota vigorosa e dominância da espécie em seu estrato arbóreo; manejo realizado por populações locais, que se beneficiam diretamente com a atividade florestal; a madeira de caixeta é utilizada em produtos de elevado valor agregado, como lápis especiais e saltos para sapato; seu manejo apresenta impactos ambientais inferiores a outras alternativas de uso da terra, como a pecuária e o cultivo da banana e chá. Além disso, o manejo da caixeta não envolve uso de agrotóxicos (Viana, op. cit.).

Em 2001, foi realizado o Plano Estratégico de Negócios (PEN) para produtos feitos com caixeta, que teve como consequência a fundação da REDE CAIXETA. Entidade que visa unificar todas as iniciativas produtivas e de apoio ao manejo da espécie. Fazem parte da REDE CAIXETA: Associação dos Caixeiteiros (ACAX); ESALQ/USP; Programa da Terra (PROTER); Associação Jovens da Juréia (AJJ); e, pequenos agricultores de Cananéia-SP.

Pesquisa de mercado realizada para o PEN (PROTER, 2001) encontrou os seguintes produtos como promissores: pequenos objetos decorativos; molduras; brinquedos educativos; madeira serrada para exportação; tabuinhas para lápis cosmético; peças para calçados; e, móveis pré-escolares e infantis. De acordo com a análise econômica, o mercado de produtos finais é o segmento de mercado mais rentável 
financeiramente para as serrarias. Porém, os preços considerados foram excessivamente otimistas.

Outro mercado promissor é o de molduras. Nesse caso, as peças são estreitas e finas, resultando em maior aproveitamento da madeira em toras. Este mercado sofre competição acirrada por pinus e marupá. Neste mercado, existem as empresas que fabricam as barras de molduras (normalmente em comprimento de cerca de 2,70 m), através de processo mecanizado, e vendem para as lojas de molduras, que cortam as barras no formato encomendado pelo consumidor final. A maioria das molduras existentes no mercado brasileiro são fabricadas no Rio Grande do Sul. As madeiras provêm, em grande parte, de Rondônia, são levadas para o Sul, depois de secas e tratadas, são perfiladas e enviadas para o mercado consumidor (São Paulo, Minas Gerais, Rio de Janeiro).

Nesse mercado, a qualidade requerida para o material é muito elevada, exigindo elevado grau de profissionalização da serraria. A madeira deve ter uma baixa absorção de água, não pode empenar e deve ter resistência para dimensões estreitas (finas). $\mathrm{O}$ acabamento da madeira exige a secagem em estufa, trifilagem e plainagem. $\mathrm{O}$ comprimento $(2,70 \mathrm{~m})$ exigido na produção dessas barras de molduras pode inviabilizar o uso da caixeta, que é uma espécie de madeira tortuosa, o que implica em baixo rendimento em relação a largura e comprimento da madeira serrada.

No mercado de brinquedos educativos, móveis pré-escolares e infantis, a caixeta possui vantagem de ser uma madeira potencialmente correta nos sentidos ambiental e social. Ela não lasca e tem peso leve. Em brinquedos maiores, trata-se de vantagens comparativas em relação às madeiras de lei.

O PROTER (2001) ainda considera como mercados promissores: madeira e peças para artesanato; madeira (varas) para aeromodelismo; e, tábuas para pequenos móveis. Também foram considerados como mercados potencialmente promissores, mas não testados: peças para instrumentos musicais; tábuas para as indústrias de móveis; tábuas para exportação; madeira para cabos de pincéis; e, tampas de vidros.

O mercado de tabuinhas, apesar de muito restrito, ainda possui vantagens, como alta demanda por mão-de-obra. Pesquisas por novos mercados (externos) têm sido 
realizadas pela serraria "O Casqueiro" de Paranaguá-PR. Lotes de amostras de tabuinhas de caixeta foram enviadas para Canadá, EUA, Alemanha, México, Holanda e Suiça. Porém, ainda não existe um conhecimento de qual a potencialidade destes mercados, já que a caixeta nunca foi usada na produção de lápis no exterior

O preço da madeira de caixeta, nos últimos anos, tem sofrido dificuldades na competição com outras espécies, especialmente, com madeiras vindas de reflorestamento de pinus (Viana et al., 1996). O preço médio da madeira serrada de pinus, em 2001, foi de $\mathrm{R} \$ 155,82 / \mathrm{m}^{3}$ (Empresa Brasileira de Pesquisa Agropecuária, 2002). Nesta época, no Vale do Ribeira, o preço médio da madeira serrada de caixeta foi

de $\mathrm{R} \$ 300,00 / \mathrm{m}^{3}$. No entanto, esta diferença não se demonstra relevante quando comparado o preço da madeira em toras em pé para o produtor. O preço médio de toras em pé de pinus para o produtor foi de $\mathrm{R} \$ 23,11 / \mathrm{m}^{3}$, em 2001 (EMBRAPA, 2002). Enquanto que o preço da caixeta em pé para produtores do Vale do Ribeira foi cerca de $\mathrm{R} \$ 25,60 / \mathrm{m}^{3}$.

\subsection{Cadeia produtiva}

\subsubsection{O processo de extração}

Na cadeia produtiva da caixeta podemos encontrar os seguintes agentes: proprietário do caixetal (da terra); caixeteiro; pessoas responsáveis pelo seu processamento primário e acabamento, na serraria; artesãos; indústrias; distribuidores e lojas (Figura 6). Os caixeteiros são pessoas que trabalham na colheita da caixeta, seja como operador de motosserra ou ajudante (Diegues et al., 1991; Nolasco, 2000).

O processo de extração da caixeta compreende as atividades de corte da árvore e de transporte da madeira até o local onde se encontra o caminhão ("porto"), que a levará até a serraria. A colheita da caixeta é uma atividade exclusivamente masculina (Diegues et al., 1991) e considerada pelos caixeteiros como um trabalho difícil, já que normalmente trabalham em condições adversas. Estão sempre sujeitos a acidentes com a 
queda das árvores ou das copas que ficam suspensas após o corte, estando também sujeitos a picada de animais peçonhentos (Nolasco, 2000).

Mesmo em condições adversas, os caixeteiros mostram interesse em continuar ou retomar a atividade (Nolasco, 2000). Isso pode ser compreendido devido às poucas alternativas de trabalho na região, geralmente com baixos salários (como a pesca da manjuba) e sujeitas a sazonalidade. Um outro fator que contribui é o fato da atividade estar relacionada a honra masculina, já que necessita de coragem e força física (Diegues et al., 1991). 


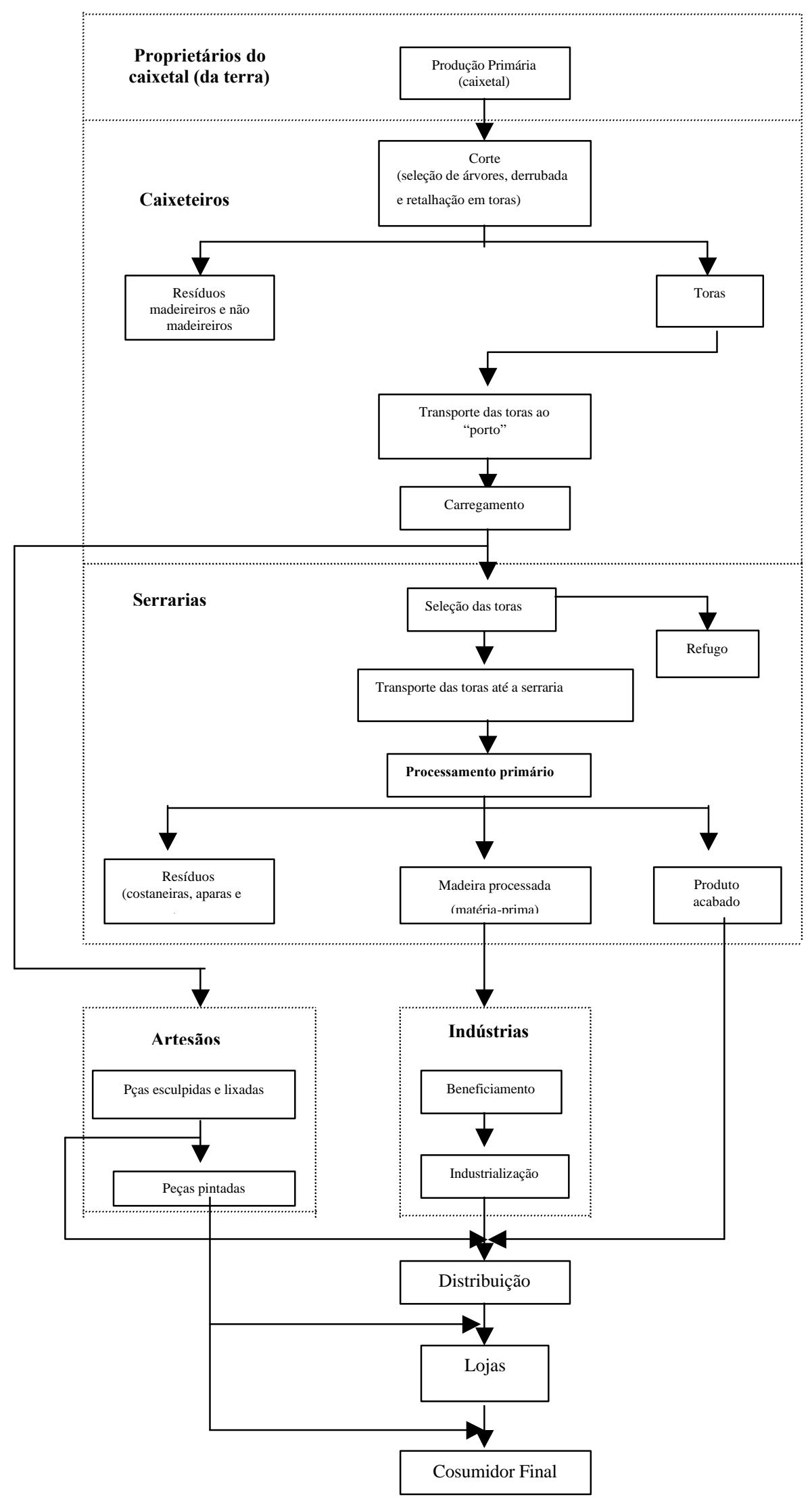

Figura 6 - Fluxo de Produto (madeira e seus subprodutos). 


\subsubsection{Corte}

O corte, no modo de extração tradicional, compreende as tarefas de seleção de árvores, derrubada e retalhação em toras (Figura 7).

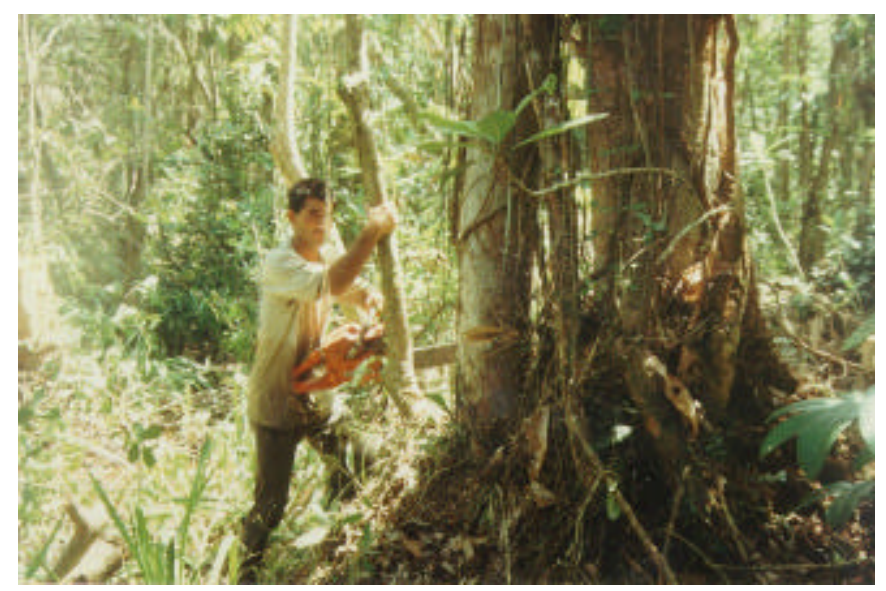

Figura 7 - Caixeteiro realizando o corte da árvore.

A seleção de árvores é baseada na prática e experiência do caixeteiro na atividade extrativista, além de instruções e informações que são passadas de pai para filho, pela serraria ou pelo caixeteiro empreteiro (Diegues et al., 1991). Quanto à derrubada, a altura do corte depende da área em que se encontra o caixetal. Nas áreas úmidas, que são alagadas o ano todo, o corte é mais alto, atingindo cerca de $100 \mathrm{~cm}$, garantindo que a cepa permaneça $20 \mathrm{~cm}$ acima do nível da água. Nas áreas mais secas, a altura do corte depende da estação, podendo ocorrer abaixo de $20 \mathrm{~cm}$ do nível da água com variação entre 30 e $70 \mathrm{~cm}$ de altura (Diegues et al., 1991; Nolasco, 2000).

A altura do corte, em relação às condições da área em que se encontra o caixetal, deve ser observada com atenção, já que existe o perigo de apodrecimento da árvore quando o nível da água ultrapassa a linha de corte. Por outro lado, quanto mais alto o corte, mais difícil e demorada é a regeneração da árvore (Diegues et al., 1991). 
Antes de se iniciar a retalhação, após a derrubada, é feito o desgalhamento que indica retirada de plantas que ficam aderidas ao tronco, como cipós e epífitas. Esta etapa é realizada com o auxílio de foice, facão ou motosserra. A retalhação do tronco em toras pode variar entre 1,0 e 1,20 m de comprimento. Diegues (1991) encontrou a medida de 1,20 m de comprimento como a mais comum. No entanto, Nolasco (2000) encontrou a medida modular de 1,05 m de comprimento.

O processo de extração dá origem a resíduos madeireiros e não madeireiros que podem ser classificados em galhos com até $5 \mathrm{~cm}$ de diâmetro (DAP), árvores quebradas acidentalmente, toras abandonadas ou esquecidas, bromélias e outras espécies associadas ao caixetal que sofrem danos durante a colheita e que teriam potencial para uso (Nolasco 2000). O tipo e a quantidade de resíduos gerados na extração da caixeta está relacionado com o destino da madeira de acordo com o produto a ser produzido. O tamanho do diâmetro requerido para a produção de saltos para calçados e para lápis é maior que para artesanatos. Isso implica em maior aproveitamento da madeira e de resíduos madeireiros (galhos) na colheita para artesanato.

$\mathrm{Na}$ colheita de madeira para lápis existe um aproveitamento relativo de $45.6 \%$ da madeira. Neste caso, o diâmetro (DAP) mínimo para corte é de $12 \mathrm{~cm}$. Para tamanco, cujo DAP mínimo exigido é de $15 \mathrm{~cm}$, o aproveitamento da madeira é de 35.6 \% (Nolasco 2000). O principal resíduo, não madeireiro, da extração da caixeta são as bromélias (epífitas) (Figura 8). Existe uma quantidade média de 12 bromélias, por árvore, para as árvores que se encontram na classe de diâmetro entre 15 e $25 \mathrm{~cm}$ (Silva, 2000). No caso das árvores que estão na classe de diâmetro entre 25 e 35 cm, a quantidade média é de 16 bromélias/árvore (Silva, 2000). Estes resíduos são recursos florestais com grande potencial de aproveitamento (Nolasco, 2000). 


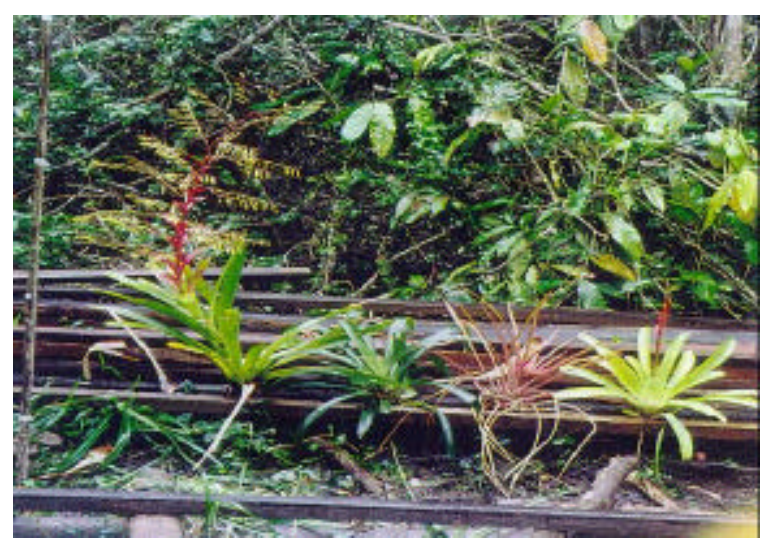

Figura 8 - Resíduos não madeireiros (bromélias) da colheita da caixeta. Fonte: Nolasco, A.M. (2000)

\subsubsection{Transporte}

O transporte ou deslocamento da madeira até o "porto" pode ser realizado por uma série de operações. Cada área de caixetal exige uma forma diferenciada de retirada da madeira até o "porto", podendo muitas vezes exigir vários tipos de transporte. As formas de transporte existentes no Vale do Ribeira são as seguintes:

a) Transporte Manual

Consiste em carregar as toras do local onde foram cortadas até o local ("porto") onde serão empilhadas, medidas e depois transportadas até o local de beneficiamento. As toras são carregadas por caixeteiros, que as colocam sobre os ombros (Figura 9). Regionalmente esta etapa da extração da caixeta é conhecida como "picada" ou "tombamento da madeira" (Diegues et al., 1991). 


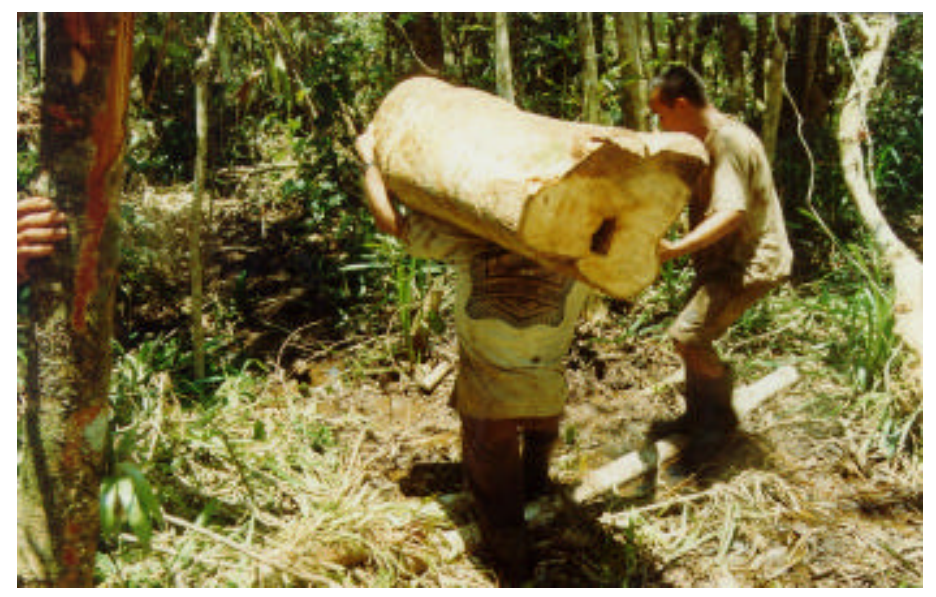

Figura 9 - Transporte braçal das toras ao "porto".

b) Transporte por valas ou fluvial

Este tipo de transporte é usado em áreas úmidas, que permanecem alagadas durante todo o ano. A "vala" consiste na utilização de flutuações para o deslocamento da madeira. As valas são construídas antes do início da colheita, na forma de aberturas feitas no brejo. Existem as valas principais, geralmente perpendiculares à linha do trilho ou à estrada aterrada; e as valas secundárias, mais estreitas e menos profundas, dispostas em forma de quadras e distantes entre si aproximadamente $200 \mathrm{~m}$. Em áreas mais secas, é comum a abertura de valas, esperando o período de chuvas, o que facilita o transporte.

Antes de serem colocadas na vala, as toras, são unidas por grampos através de suas extremidades, formando uma "trilha", constituída de 1,00 mst de madeira. As toras podem ser puxadas através da vala com o auxílio de uma canoa ou pelo próprio caixeteiro (Diegues et al., 1991). 
c) Transporte por trilhos

Utilizado em áreas úmidas, que durante o inverno permanecem mais secas, consiste em uma linha de trilhos de madeira ou ferro dispostos de forma irregular. No trilho é utilizado um veículo conhecido como vagonete ou trole, construído com chão de caibros, podem carregar 1,00 mst de caixeta, equivalente a $500 \mathrm{~kg}$ (Diegues et al., 1991) (Figura 10)

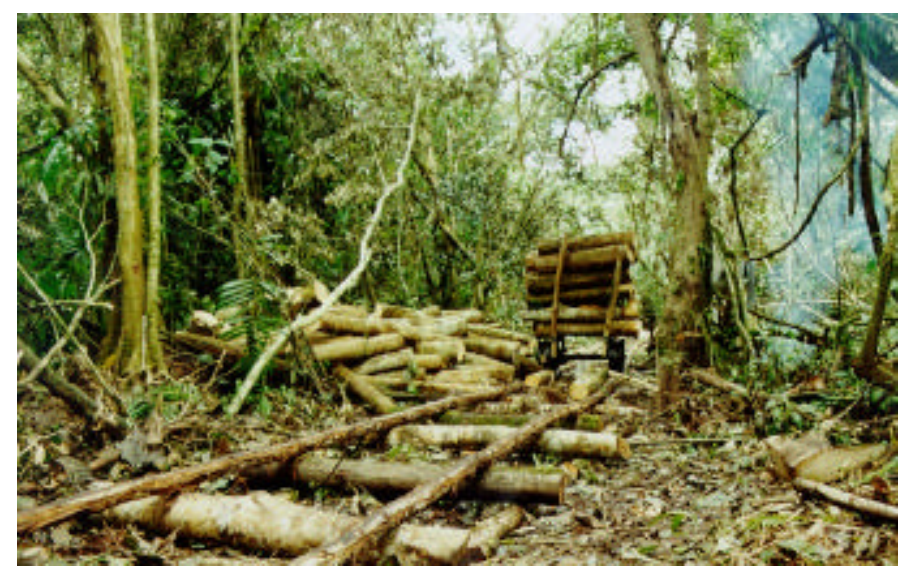

Figura 10 - Transporte por trilhos das toras ao "porto".

d) Transporte por trator e carretas

Normalmente é usado após o transporte por "vala" ou "trilho", quando o acesso ao caminhão se torna difícil devido às características geográficas do terreno ou da estação (Diegues et al., 1991).

e) Transporte por barco

É utilizado para a travessia de rios quando o caixetal está localizado do lado oposto da serraria e o custo por via terrestre é maior. Em pequenas distâncias, os barcos utilizados possuem capacidade entre 4,00 e 30,00 st. Para maiores distâncias, esse tipo de transporte é viável somente quando o barco possui capacidade superior a 15,00 st (Diegues et al., 1991). 
f) Transporte por caminhão

Consiste no transporte das toras de caixeta do "porto" até a serraria, oficina dos artesãos ou fábricas. No "porto" ocorre o carregamento, que consiste na colocação das toras empilhadas sobre o caminhão que as transportam até o destino (Figura 11). Nesta etapa aparece o refugo. No "porto", o comprador faz uma seleção das toras que serão úteis para o processamento primário, sendo o restante abandonado.

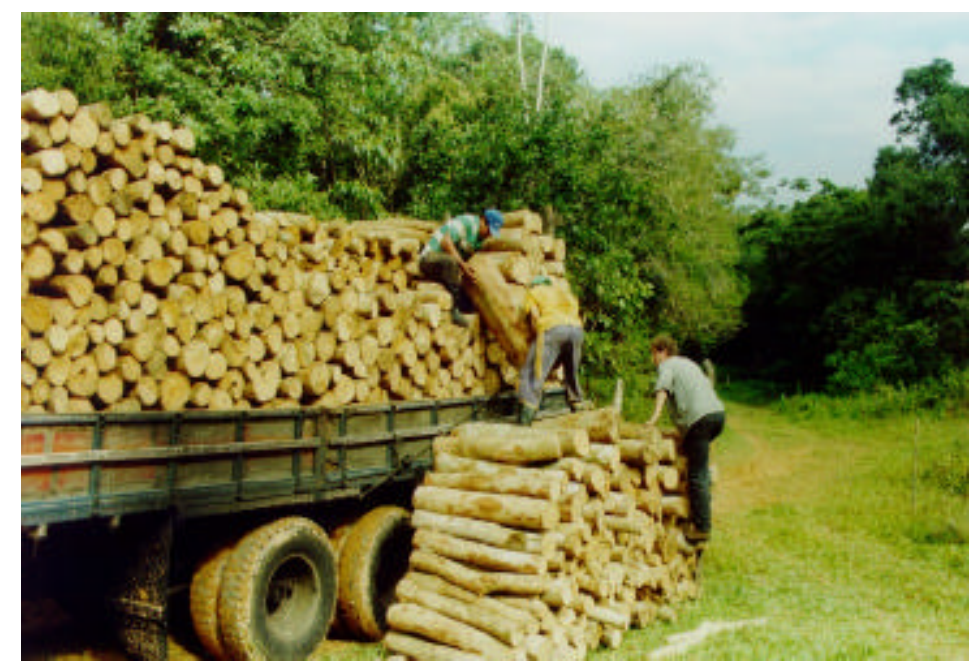

Figura 11 - Carregamento das toras no "porto".

O comprimento, diâmetro e formato, das toras a serem extraídas, são especificados pela serraria de acordo com o produto a ser processado (Nolasco, 2000). Para a produção de tamanco, o DAP mínimo adotado é de $15 \mathrm{~cm}$. Para lápis, o DAP mínimo especificado é de $12 \mathrm{~cm}$. Tradicionalmente, as serrarias adotaram como padrão de colheita, árvores com diâmetro superior a $12 \mathrm{~cm}$ e toras com comprimento de 1,05 m (Nolasco, 2000). A caixeta apresenta forma tortuosa e indivíduos que possuem distribuição diamétrica entre 10 e $20 \mathrm{~cm}$ de DAP, o modelo adotado pelas serrarias foi adaptado do uso de madeiras de reflorestamento que, diferente da caixeta, possuem fuste mais reto e de maior diâmetro (Nolasco, 2000). 
As árvores são cortadas, desgalhadas e retalhadas em toras com casca. Depois de transportadas, são serradas e processadas, na serraria, conforme as necessidades do produto a que terão destino. A etapa seguinte será a industrialização ou o artesanato. Em alguns casos, o produto final pode ser fabricado e acabado na serraria.

\subsubsection{Comercialização}

A compra da madeira em toras pela serraria, fábricas e oficinas de artesanato $^{12}$, pode ocorrer de duas formas: ela pode comprar a área do caixetal pagando pela árvore "em pé” (matagem) ao proprietário, que contrata o caixeteiro para a colheita e transporte das toras ao "porto". O comprador é o responsável pelo transporte das toras do "porto" à serraria. Elas também podem encomendar a caixeta para o caixeiteiro, que irá negociar o preço da madeira com o proprietário. Neste caso, o transporte das toras do "porto" até a serraria também é pago pelo comprador (Figura 12).

Em um segundo momento, as toras serão processadas, na serraria, e depois fornecidas às indústrias para o beneficiamento e a industrialização. A próxima etapa será o fornecimento das indústrias para distribuidores que, por sua vez, fornecerão aos lojistas que venderão aos consumidores finais.

A comercialização do artesanato de caixeta ocorre de três formas: o artesão pode negociar suas peças diretamente com lojistas, que as vendem ao consumidor final. A negociação também pode ocorrer através de distribuidores, que compram as peças dos artesãos e depois as revendem para lojistas de diversas regiões do país e do exterior (Japão, EUA e Itália), ou ainda, podem vendê-las em feiras e lojas regionais especializadas em artesanato (Nolasco \& Armelim, 1997; Nolasco et al., 1999; Nolasco, 2000).

\footnotetext{
${ }^{12}$ Atualmente, os artesãos da AJJ estão comprando a madeira diretamente do caixeteiro, que negocia a matagem com o proprietário da terra. Os artesãos pagam pelo transporte das toras do "porto" até a sede da Associação, onde são processadas, esculpidas, lixadas e pintadas (Figura 12).
} 
No caso de produtos acabados, os distribuidores entram em contato com as serrarias a respeito da necessidade do mercado por esses produtos. A serraria compra as toras do proprietário do caixetal ou do caixeteiro, sendo a responsável pelo transporte da madeira do "porto" até a serraria. As toras serão processadas e, em seguida, é dado o acabamento conforme as características do produto final. Depois de acabadas, são enviadas aos distribuidores, que fornecerão a lojistas que venderão aos consumidores finais (Figura 12).

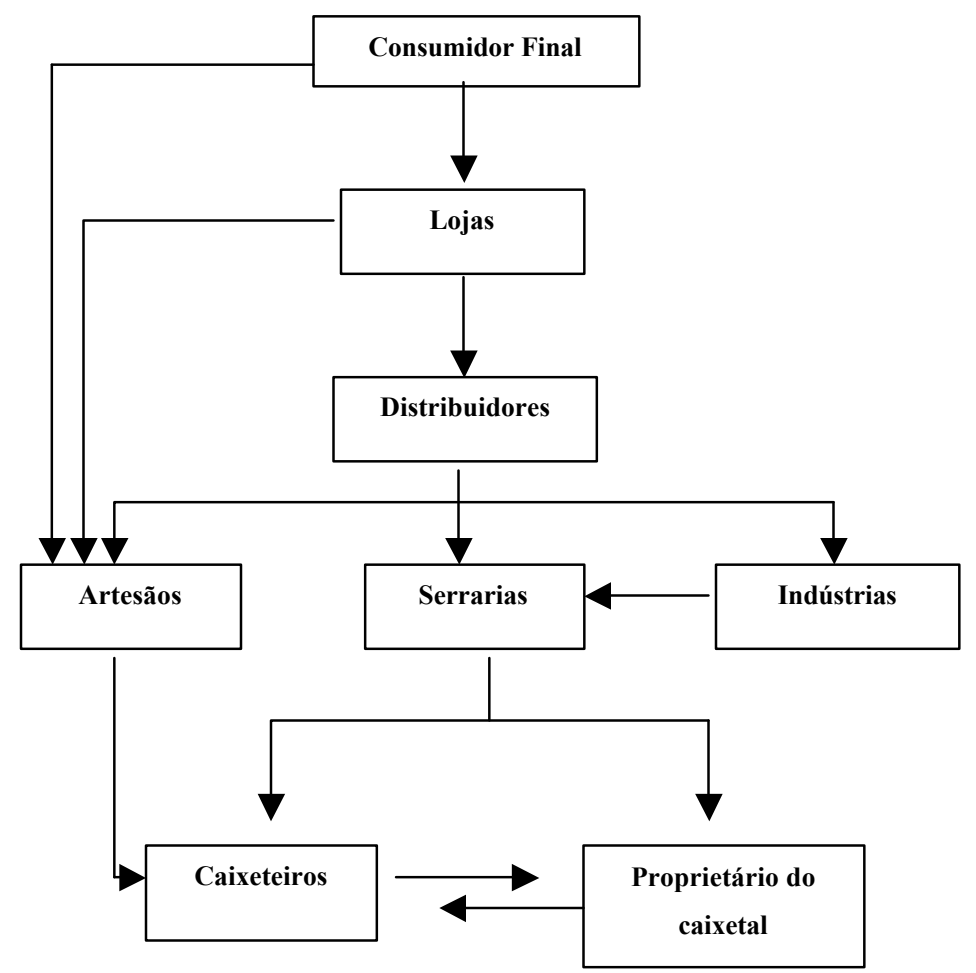

Figura 12 - Fluxo de informação da cadeia agroindustrial da caixeta. 


\subsubsection{Evolução do preço da caixeta}

Infelizmente, a literatura é bastante escassa com relação às informações econômicas sobre a caixeta. Em particular, não existe uma série longa de preços de caixeta em toras. Até meados da década de 80, a caixeta era predominantemente considerada como lenha e não como matéra-prima madeireira para processamento com finalidades industriais ou para o artesanato. Dentre outros valores, os preços para toras de caixeta foram estimados em NCZ\$ 21,17/mst para os anos de 1988/89 (o que corresponde a R \$ 8,00 $\mathrm{mst}^{-1}$ em 2001) (Diegues et al., 1991) e R \$ 35,00 para os anos de 1996/1997 (que em 2001 representaria $\mathrm{R} \$ 52,00 \mathrm{mst}^{-1}$ ) (Nolasco 2000).

\subsubsection{O processamento da caixeta}

Nas serrarias, a maior parte $(80 \%)$ dos funcionários possuem contrato formal de trabalho (Nolasco, 2000; Diegues et al.,1991). O restante, trabalham como diaristas. A remuneração desses funcionários varia entre 1,00 e 3,8 salários mínimos (Nolasco, 2000).

No final da década de 80, quando várias serrarias trabalhavam com a caixeta, o nível salarial médio nas serrarias era de cerca 1,5 salário mínimo (ou R\$ 300,00 em valores atuais). Na serraria comunitária da ACAX, atualmente, os trabalhadores são pagos por dia de serviço prestado. O pagamento ocorre semanalmente e os trabalhadores recebem, em média, R\$ 15,00/dia (PROTER, 2001).

Um aspecto da relação trabalhista da região do Vale do Ribeira é a predominância do trabalho informal. Geralmente as pessoas recebem por dia de trabalho e não há contrato formal entre trabalhador e empregador. Isso acaba favorecendo as faltas ao serviço, no caso de existir um outro serviço com maior rendimento. Isto ocorre, com freqüência, na época da safra da manjuba (PROTER, 2001).

Nolasco (2000) estudou o processamento primário da caixeta, em serrarias, que davam origem a peças brutas de tabuinhas para lápis, tamancos e 
artesanato. A serraria de tabuinhas para lápis estudada por Nolasco (2000) com capacidade para processar cerca de $5.298 \mathrm{~m}^{3} /$ ano de madeiras em toras, processou, no período de 1991 a 1997 , em média, cerca de $2.139 \mathrm{~m}^{3} /$ ano. A serraria para tamancos operou esporadicamente (sob encomenda) nos anos de 1994 a 1997, processando, em média, 69,5 m³/ano e a de artesanato, com início da produção em 1996 processou, em média, $22,5 \mathrm{~m}^{3} /$ ano.

A produção de tabuinhas para lápis, em média, foi de 6.950 grosas de caixeta por mês, a margem de lucro para a produção de tabuinhas de caixeta foi cerca de 6,03\%. A serraria analisada também produz tabuinhas de gmelina (7.230 grosas/mês), que aumenta sua margem de lucro em 33,01\%.

O desdobro da caixeta, no caso da produção de lápis, passa pelas seguintes operações: recebimento das toras; desdobramento em pranchas; formação e uniformização de tabuinhas; seleção; e, embalagem (Figura 13).

A serraria de processamento de tamancos, estudada por Nolasco (2000), obteve maior margem de lucro, cerca de 65,07\%, com produção média de 1.312 pares/mês, volume inferior a sua capacidade instalada (8.000 pares/mês). A alta margem de lucro pode ser explicada pelo melhor aproveitamento da matéria-prima, cerca de $55,37 \%$ e menor número de funcionários (Nolasco, 2000). O processamento primário da caixeta para tamancos ocorre em duas etapas: primeiro a madeira é serrada e, em seguida, lixada. A montagem e acabamento, normalmente, acontecem na indústria, mas também pode ocorrer na serraria (Figura 14).

A serraria que produz peças para artesanato manteve uma produção constante de 6.000 peças/mês, com margem de lucro de 16,55\%. No caso do processamento para artesanato as peças são serradas, esculpidas, lixadas e pintadas por artesãos. O valor das peças de artesanato, acabadas, pode variar entre $\mathrm{R} \$ 0,50$ e $\mathrm{R} \$ 6,00$. As peças para artesanato podem ser serradas em vários formatos, como pássaros e peixes. Neste caso, as toras de caixeta são desdobradas e em cada tábua são carimbados desenhos, que posteriormente são recortados em serra de fita (Nolasco, 2000) (Figura 15). Neste tipo de processo, as peças não recebem nenhum tipo de acabamento e podem ser encontradas no mercado com valores entre $\mathrm{R} \$ 0,10$ e $\mathrm{R} \$ 1,50$. 
Para Nolasco (2000) os fatores que limitam a produção nas serrarias são: a escassez de madeira no mercado, devido à demora e dificuldade de obtenção dos planos de manejo para a caixeta; restrição no mercado para produtos de caixeta, resultado do período de suspensão de colheita da espécie; falta de capacitação técnica e administrativa dos responsáveis pelas serrarias na busca de novos produtos e abertura de novos mercados. 


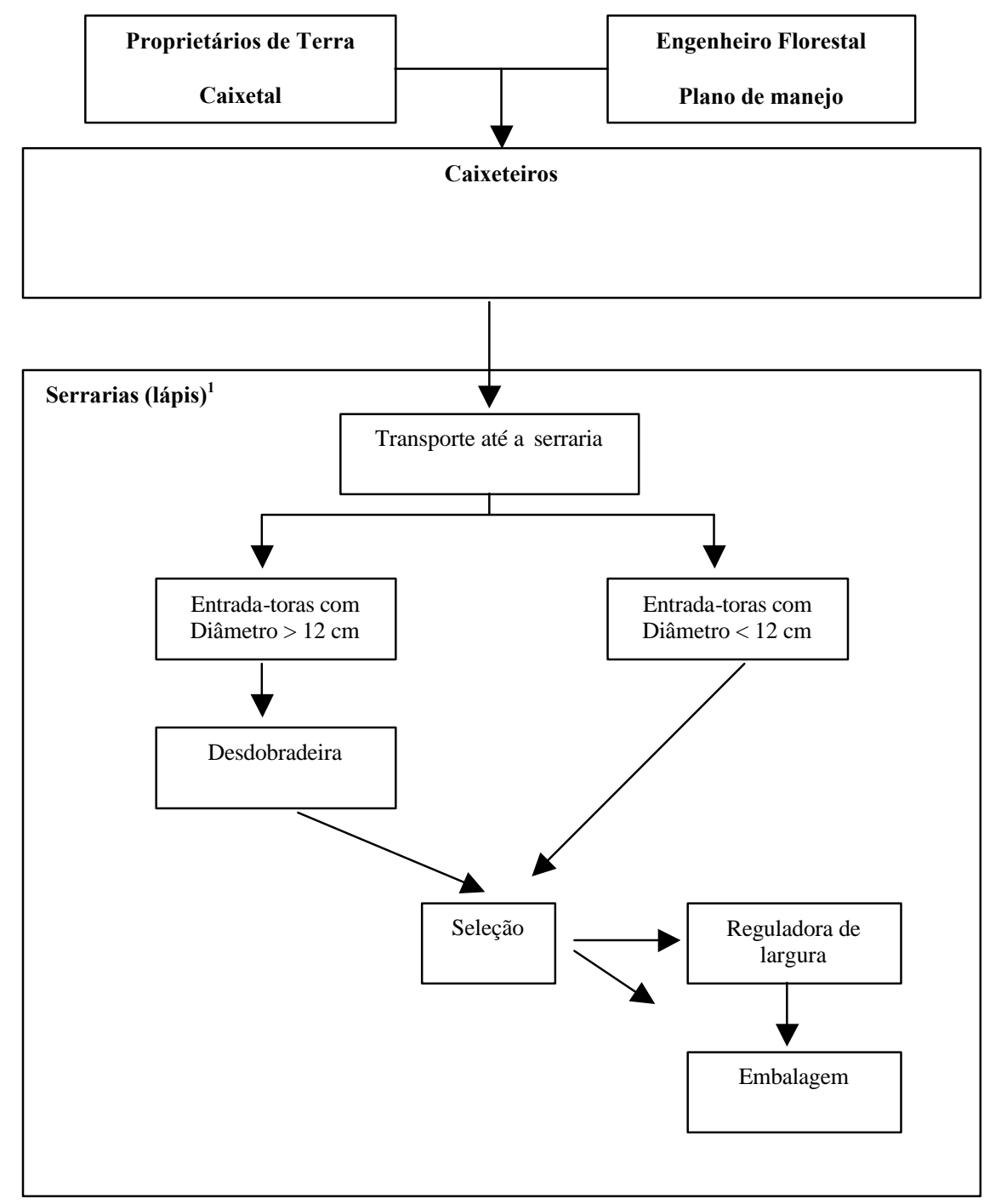

Figura 13 - Fluxo de Serviços na operação de extração e processamento da Caixeta para lápis.

${ }^{1}$ Baseado em Nolasco, A.M. (2000) 


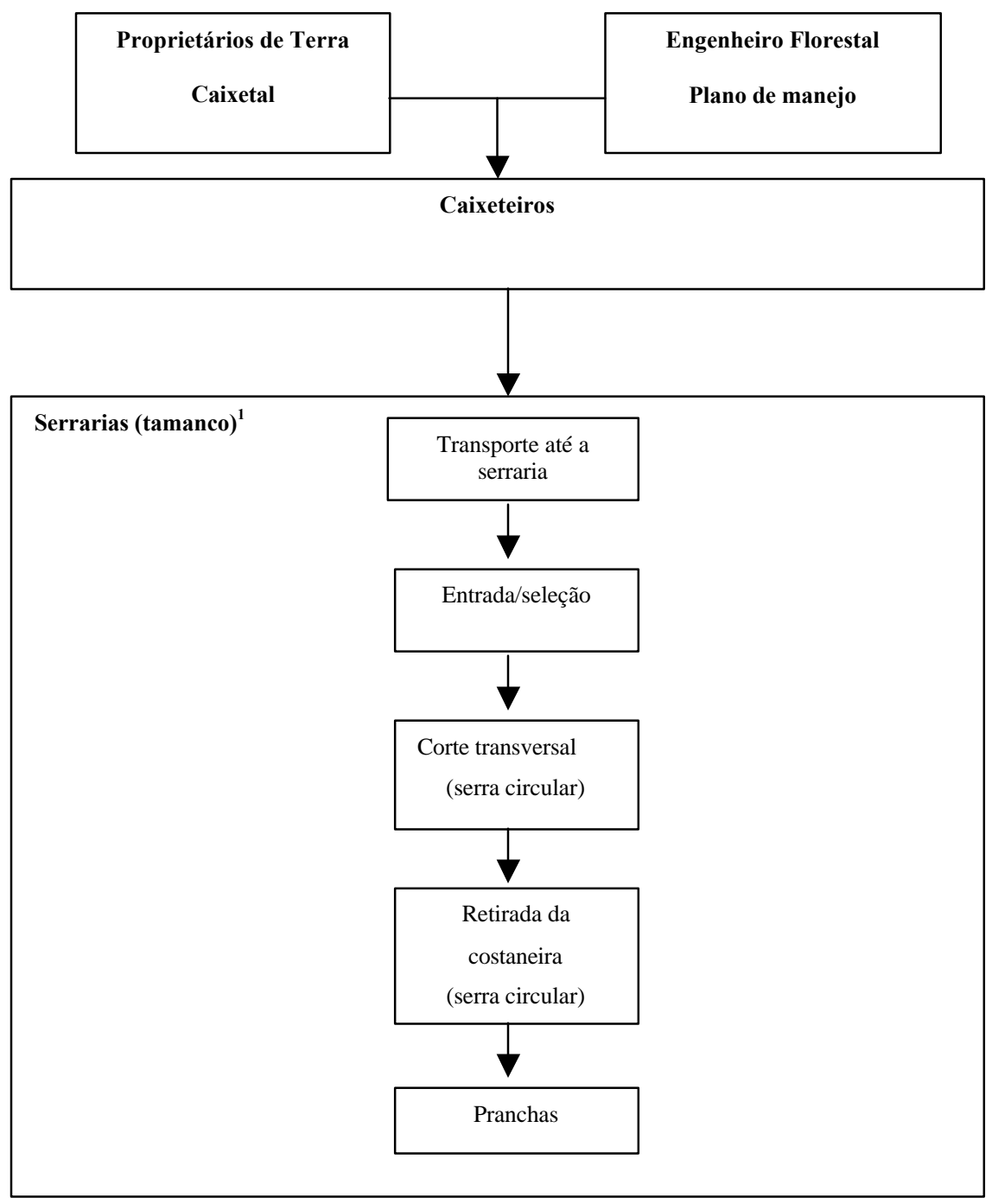

Figura 14 - Fluxo de Serviços na operações de extração e processamento da Caixeta para tamanco.

${ }^{1}$ Baseado em Nolasco, A.M. (2000) 


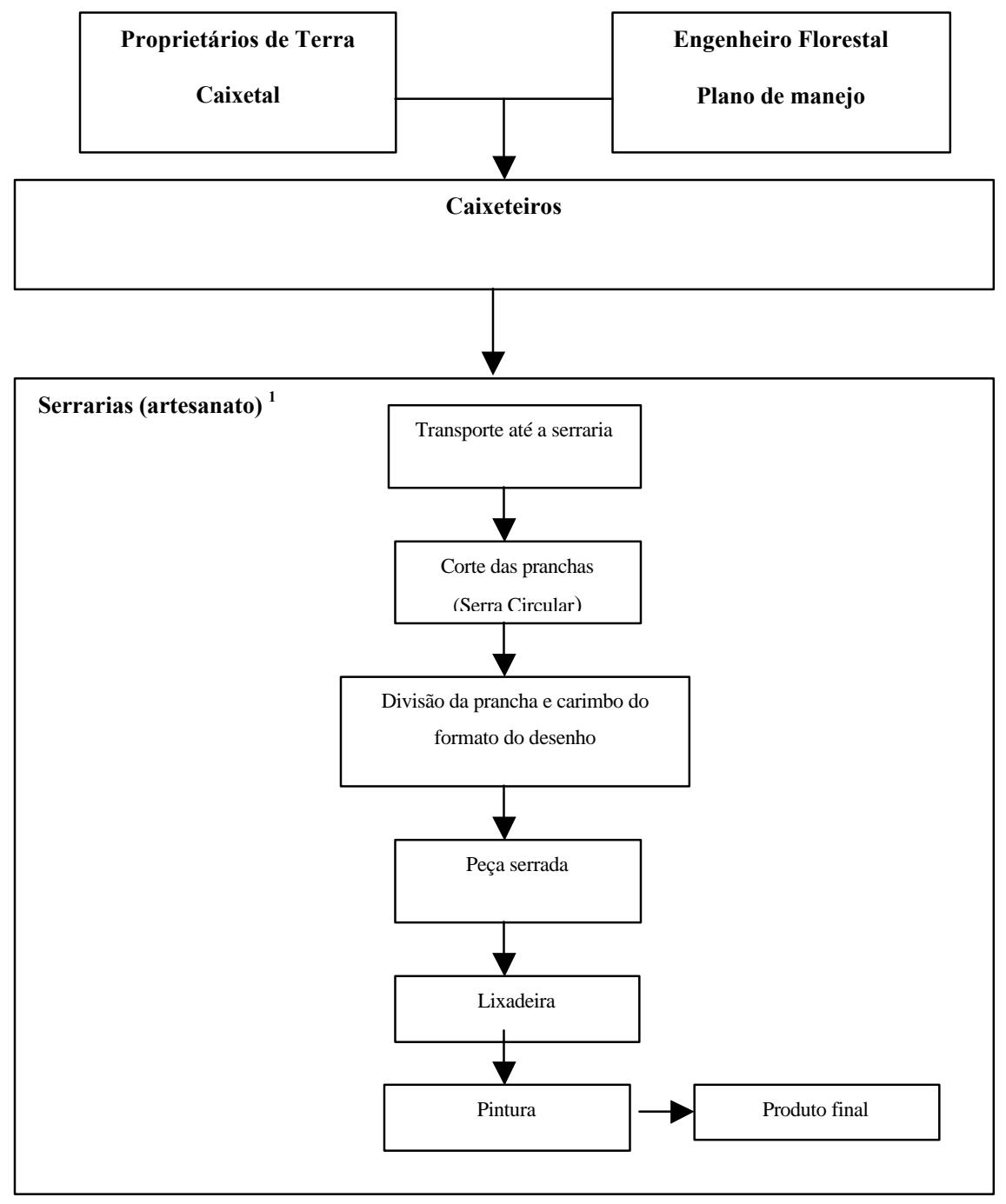

Figura 15 - Fluxo de Serviços na operação de extração e processamento da Caixeta para artesanato.

${ }^{1}$ Baseado em Nolasco, A.M. (2000)

No processamento primário da caixeta existe o problema do desperdício de matéria-prima, na forma de resíduos (Nolasco, 2000). Estes resíduos, segundo sua composição, podem ser identificados como costaneiras, serragens e aparas (Figura 16). 
Os volumes de cada uma destas formas de resíduo variam de acordo com o produto processado. Cerca de $48,21 \%$, em média, do volume de toras processadas se tornam resíduos no final do processo produtivo nas serrarias (Nolasco, 2000). Esses resíduos podem ser aproveitados na fabricação de pequenos objetos de madeira, como vasos; como fonte de energia; para cobertura do solo; e, como substratos no cultivo de cogumelos (Nolasco, 2000).

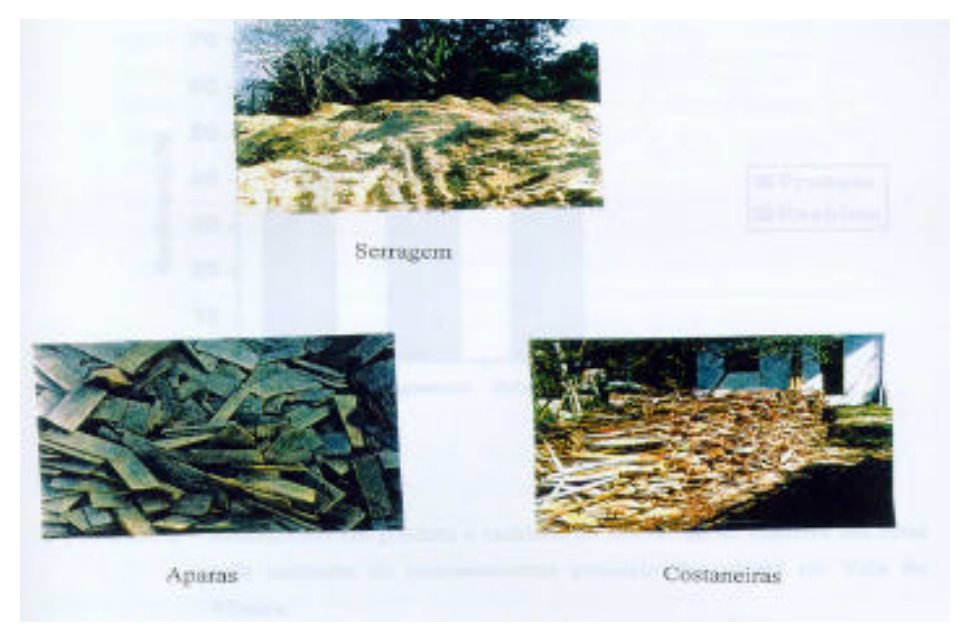

Figura 16 - Resíduos madeireiros do processamento da caixeta (costaneiras, serragens e aparas).

Fonte: Nolasco, A.M. (2000) 


\section{ECONOMIA DA EXPLORAÇÃO DA CAIXETA}

\subsection{Aspectos teóricos e metodológicos: uma revisão da literatura}

A literatura acadêmica que aborda a economia da exploração de um recurso biológico extrativo é ainda bastante limitada, apesar do crescimento recente. A seguir são apresentadas algumas referências relevantes para o presente estudo.

O trabalho realizado por Peters et al. (1989) teve como enfoque a valoração dos recursos não madeireiros extraídos em florestas nativas de Mishana (Peru), mostrando a importância e a viabilidade da atividade extrativista, como fonte de renda, para a população nativa. Em um primeiro momento, os custos de coleta, transporte e regeneração foram estimados para, em seguida, a margem bruta anual (V) de um hectare (ha) de floresta ser obtida. O Valor Presente Líquido (VPL) foi estimado como sendo a relação entre a margem bruta anual $(\mathrm{V})$ e o fator de desconto $(1+\mathrm{r})^{-\mathrm{i}}$. Neste caso, as taxas de desconto utilizadas, para a análise de sensibilidade, foram de 5\% e $10 \%$. Os resultados mostram que os recursos não madeireiros têm relevante importância para a economia regional como geradores de renda para a comunidade nativa. No entanto, para que a comercialização seja viável, é preciso que tenham significativo potencial de mercado, ou seja, que a demanda regional possa captar a oferta desses produtos.

O modelo utilizado por Peters et al. (1989) foi inovador, apresentando relevante contribuição teórica para trabalhos que analisam a viabilidade econômica em atividades extrativistas florestais. Entretanto, o modelo é limitado para a análise proposta no presente trabalho, devido à falta de incorporação de variáveis ecológicas que 
expliquem aspectos silviculturais da espécie, como a curva de crescimento. A existência de variáveis ecológicas, em modelos que analisam a extração de recursos madeireiros em florestas é essencial para que o ponto econômico ótimo de corte seja obtido de acordo com as características botânicas específicas da espécie estudada.

O trabalho de Pinedo-Vasquez et al. (1992) examina e compara a viabilidade econômica da extração de madeira, da agricultura rotacional e da colheita de frutas e látex para a população rural da Amazônia Peruana. Essas atividades são as principais fontes de renda da população regional, que as priorizam sob bases habituais e culturais. O estudo avaliou e comparou o retorno econômico relativo das atividades econômicos de uso da terra existentes na região. Essa análise mostra que a agricultura e a extração de madeira podem trazer retornos econômicos parecidos.

Como no estudo realizado por Peters et al. (1989), os recursos não madeireiros possuem relevante contribuição na renda desde que haja significativa demanda no mercado regional. O modelo teórico usado para a avaliação econômica dos custos e benefícios da atividade extrativista de madeira foi baseado em dados oficiais do Ministério da Agricultura Peruano. A análise estima a rentabilidade da madeira sob a pressuposição de que toda a madeira existente é extraída em um único período. Os resultados mostram que a receita líquida obtida para o primeiro hectare de floresta cortada é positiva e que a receita esperada, para os próximos hectares, é mais alta que a do primeiro corte.

Ricker et al. (1999) aplicou e desenvolveu novos métodos em análises econômica e ecológica de florestas visando mostrar seu potencial através da análise benefício-custo no curto-prazo. Este procedimento foi utilizado para calcular o valor comercial do "plantio de enriquecimento" com dados coletados em um período de três anos. A espécie de árvore escolhida, Pouteria sapota (Jacquim) H.E. ocorre, naturalmente, em baixa densidade ${ }^{13}$.

\footnotetext{
${ }^{13}$ Cerca de uma árvore por hectare.
} 
Este caso de estudo, realizado em uma floresta do México, revelou que o uso do "plantio de enriquecimento", com espécies de árvores nativas, é uma excelente proposta de manejo que aumenta o valor comercial da floresta, tornado-a competitiva em relação a usos da terra que implicam na conversão de florestas para agricultura e pecuária. Os resultados mostram que, dependendo do valor da terra, um plantio com variação maior que 40-200 sementes por hectare, em floresta natural, faz com que o valor presente líquido esperado seja maior que o encontrado para um hectare de floresta que tenha sofrido conversão para pastagem.

Essas conclusões foram possíveis devido a extensas pesquisas realizadas com enfoque no crescimento e na produção de frutos, da espécie selecionada. Este critério, usado para encontrar o valor presente da árvore, poderá ser modificado e utilizado para o caso da caixeta. A alteração será referente a exclusão do custo de plantio e gerenciamento, que no caso da caixeta não existe devido a espécie ser nativa. Uma outra observação é que, neste caso, a avaliação foi referente a produção de frutos e no caso da caixeta será a produção de madeira.

Alguns trabalhos realizados na Amazônia Brasileira tiveram contribuição significativa para o esclarecimento e seleção dos objetivos a serem atingidos. Esses trabalhos também terão importância relevante na elaboração dos questionários de campo

Noronha et al. (1983) calculou, pela primeira vez no Brasil, o custo de produção de borracha em seringais nativos, chegando a conclusão de que o seu custo médio ainda é muito elevado em relação ao custo da borracha importada. Constatou-se que a participação relativa do seringueiro, no custo total, é cerca de $66,72 \%$, enquanto a do seringalista é de $33,27 \%$. Esta diferença ocorre devido a grande parte dos custos do seringalista serem transferidos ao seringueiro através de mecanismos de fornecimento de insumos produtivos e alimentos e, também, pelo fato de a borracha ser comprada em condições de mercado que podem ser caracterizadas como monopsônio. Uma outra conclusão muito importante e interessante é de que não se tem evidência de que o custo da borracha nos seringais nativos possa ser reduzido, já que ganhos obtidos com a redução nos preços de insumos e alimentos, possivelmente, não seriam repassados aos 
seringueiros devido a estrutura de comercialização desses produtos, nos seringais tradicionais.

Uhl et al. (1991) analisou as consequências ecológicas, econômicas e sociais da extração seletiva de madeira no município de Tailândia-PA. Nesta região existe um grande número de serrarias (cerca de 48 foram levantadas por esse estudo no ano de 1989), que possuem, em média, uma capacidade produtiva entre $250-350 \mathrm{~m}^{3}$ de madeira serrada por mês. O estudo enfatiza o processo de extração e de beneficiamento, analisando a participação econômica, social e ecológica das pessoas envolvidas na extração e no processamento. Para isso, foi realizada uma descrição precisa das características desses processos e dos tipos de danos ecológicos que causam na floresta, incluindo, a geração de resíduos.

A caracterização social e econômica desses agentes a e caracterização ecológica do ambiente analisado foram relevantes para as conclusões obtidas. Os resultados mostram que ocorrem consideráveis desperdícios durante o processo de extração. Em volume, 1,2 $\mathrm{m}^{3}$ de resíduos madeireiros são gerados para cada metro cúbico de árvore colhida. A maior parte desses resíduos (55\%) é gerada no processo de abertura do caminho para retirada da madeira da floresta. Baseado em inventário, realizado para árvores com diâmetro igual ou maior que $40 \mathrm{~cm}$, foi estimado que, em média, foram colhidos $123 \mathrm{~m}^{3}$ de madeira por hectare. Dividindo esse volume entre as pessoas envolvidas no processo de extração e aplicando os preços de mercado, o valor aproximado encontrado para a madeira em toras foi US\$2.000 ha ${ }^{-1}$. Estas informações podem ser úteis para a comparação e análise dos resultados encontrados na região do Vale do Ribeira-SP.

Verissimo et al. (1992) estudou a estrutura e a economia das indústrias de processamento de madeira ao longo de $340 \mathrm{~km}$ da rodovia Belém-Brasília, avaliando os impactos da extração de madeira e as perspectivas para seu manejo sustentável em Paragominas-PA. Este estudo abordou a relação existente entre as estruturas físicas das serrarias e as características presentes na exploração madeireira da região, avaliando o retorno econômico dos agentes envolvidos na extração e beneficiamento da madeira e os impactos que as serrarias causam sobre a população e os recursos florestais. Uma 
serraria típica da região produz, em média, $4.300 \mathrm{~m}^{3}$ ano $^{-1}$ de madeira desdobrada. Esta produção é obtida de $9.200 \mathrm{~m}^{3}$ de madeira em toras, que vale US\$ 670.800 ou US\$ 156 $\mathrm{m}^{-3}$. Os custos de produção foram estimados em US\$ $116 \mathrm{~m}^{-3}$ e a receita líquida anual em US\$ 170.000. Para as firmas que estão envolvidas tanto no processo de extração como de beneficiamento, a receita líquida anual foi estimada em US\$ 217.000 (com margem de renda igual a $32 \%$ ) ou US\$ $900 \mathrm{ha}^{-1}$ para madeira em toras.

Verissimo et al. (1995) estudou a estrutura e economia das companhias de mogno operantes no sul do Estado do Pará (maior centro de processamento de mogno na Amazônia Brasileira), apresentando a análise econômica de sua extração e processamento. $\mathrm{O}$ estudo elucidou os impactos ecológicos e sociais da extração de mogno nessa região, considerando os obstáculos e o potencial existentes para o manejo sustentável da espécie na Amazônia Brasileira. Aspectos ecológicos da espécie, como estrutura genética e tamanho da população, são alguns dos obstáculos enfrentados. Impactos indiretos agravam o potencial de sustentabilidade do mogno, como a extração predatória, a conversão de áreas exploradas em pastagens, a expansão da atividade extrativista dentro de reservas indígenas e a falta de coerência nas políticas do governo federal no que diz respeito a eficiência do manejo sustentável para a espécie. Entretanto, organizações não governamentais, nacionais e internacionais, têm trabalhado na região em busca da sustentabilidade do manejo florestal.

Angelsen et al. (1999) examinou as causas da expansão de terras agrícolas e de desmatamentos na Tanzânia. A análise foi baseada na produção para subsistência enfatizando a renda necessária para a produção e alimentação por produtores rurais locais e as características existentes no mercado para que a renda relativa obtida na agricultura pudesse ser avaliada. A análise estatística mostrou que o aumento no preço de produtos agrícolas, em particular para produtos com cultura anual, é o fato que possui maior influência na expansão de terras agrícolas.

Rock (1996) analisou os fatores de desmatamento em países pobres. O desmatamento, em muitos casos, é atribuído pelas autoridades como o resultado da ação das populações rurais pobres. Este estudo usa um modelo de desmatamento baseado na decisão de alocação de trabalho por produtores rurais para, empiricamente, mostrar 
como essa decisão interage com a estrutura da política rural econômica existente. Com o intuito de determinar a extensão de áreas desmatadas em países pobres. Análise de regressão múltipla com dados cross-country sugere que políticas que intensificam a existência de pequenas propriedades agrícolas podem reduzir o movimento da população para a fronteira agrícola. No entanto, os resultados da regressão mostram que o retorno econômico, dessas áreas, depende do grau de igualdade na distribuição de terras e da extensão de rotatividade rural existente. Os resultados obtidos neste trabalho são relevantes para a análise das políticas públicas existentes no Vale do Ribeira, que causam influências na relação entre proprietários de terra e meio ambiente.

O estudo de caso realizado por Schulze et al. (1994) demonstrou como pesquisas econômicas com enfoque na inovação em sistemas agroflorestais podem trazer benefícios sociais, econômicos e ecológicos. Para isso, utilizou modelos quantitativos em análises de benefício-custo que incluem variáveis econômicas e ecológicas. Este estudo avaliou o potencial de "plantio de enriquecimento" de três árvores nativas na floresta de Kalimantan (Indonésia) que produzem frutos, sendo uma delas também usada em extrações seletivas na exploração de madeira. Este trabalho possui um importante ponto em comum com um dos problemas encontrados, no Vale do Ribeira-SP, no que diz respeito a conversão de áreas florestais para o uso de culturas agrícolas. Nos dois casos observa-se a expansão de atividades agrícolas em terras protegidas.

Logo, o método utilizado para a avaliação do retorno econômico das espécies escolhidas para a análise do "plantio de enriquecimento" é de relevante contribuição para o caso da caixeta. A análise benefício-custo realizada pode ser usada sem grandes alterações; o critério do valor presente líquido e a estrutura do modelo se ajustam à proposta de estudo idealizada para a caixeta. Um outro ponto interessante do estudo é em relação a taxa desconto e ao período escolhido para a análise. Os resultados mostram que altas taxas de desconto implicam em sustentabilidade no curto prazo e baixas taxas de desconto, em sustentabilidade no longo prazo. 


\subsection{Análise Benefício-Custo}

A análise benefício-custo tem suas raízes no trabalho do economista francês Dupuit, em 1844 (Noronha, 1981). A preocupação era mostrar a relação entre o custo de uma ponte, ou estrada, os benefícios gerados por sua construção e o preço do pedágio a ser cobrado daqueles que utilizassem dessa construção pública. Com isso, Dupuit (1844) criou o conceito de excedente do consumidor, sendo representado pela diferença entre o preço pago por um bem, ou serviço, no mercado e o valor que estaria disposto a pagar antes de desistir de comprá-lo. O benefício do bem econômico é medido por esse excedente e não pelo preço pago (Noronha, 1981).

Na prática, essa análise foi desenvolvida nos Estados Unidos, em resposta a um requerimento legal imposto em 1936 sobre projetos de recursos hídricos do governo federal (Hufschmidt et al, 1983). Na década de 50, o uso dessa análise já podia ser observado em outros países, como os integrantes da Organização das Nações Unidas, e também estava sendo usado na análise de outros setores, incluindo, planejamento urbano, transporte rodoviário e gerenciamento da qualidade ambiental. Os trabalhos realizados, desde esta época, foram influenciados pela idéia da eficiência alocativa, dando ênfase na dicotomia existente entre eficiência e equidade.

Hammond (1958) foi o primeiro analista a aplicar os princípios da análise benefício-custo para o problema do controle da poluição. Na década de 60, a análise benefício-custo deixa, portanto, de atuar apenas na avaliação de produtos comercializados e passa a abranger as áreas de educação, saúde, recreação e poluição (Noronha, 1981).

Para Pearce (1990), na análise benefício-custo o que constitui ganho ou perda depende da função objetivo escolhida. Muitas análises operam com funções baseadas sobre a eficiência econômica, ou seja, o benefício sempre deve ser maior que o custo. Essas funções são extensamente usadas devido à eficiência econômica estar incorporada, em muitas estruturas econômicas, em análises do Bem-Estar desenvolvidas no último século. Tanto os métodos tradicionais como os modernos da análise benefício- 
custo se baseiam nos princípios da Economia do Bem-Estar (Noronha, 1981). A regra formal da análise benefício-custo pode ser escrita:

$$
(\mathrm{B}-\mathrm{C})>0
$$

De acordo com Pearce (1990), as perdas ambientais podem ser consideradas como um custo que em um tempo distante poderão existir pessoas que estarão dispostas a pagar por sua existência. Neste caso, a regra básica torna-se:

$$
(\text { B- C- E) }>0
$$

Apesar de muito interessante, o conceito adotado por Pearce (1990) tornase subjetivo à medida que tenta avaliar o quanto um indivíduo estaria disposto a pagar pela existência e conservação de um dado bem. Ocorre que esse valor está diretamente relacionado com escolhas intertemporais, que podem variar muito de pessoa para pessoa de acordo com o período em questão.

A Análise Benefício-Custo pode ser feita com base em diferentes indicadores, dentre eles, o Valor Presente Líquido. Este critério será usado para encontrar o valor do metro estere da madeira de caixeta, para o proprietário da terra, que será calculado por meio do valor presente líquido esperado (VPL):

$$
V P L=\sum_{i=1}^{n}\left[(R i-C i)(1+r)^{-i}\right]
$$

Onde:

i) i é o índice que se representa o período de tempo (em anos);

ii) $\quad R_{i}$ é a receita do proprietário da terra referente à matagem, em metro estere; 
iii) $\quad \mathrm{C}_{\mathrm{i}}$ são os custos do proprietário da terra com o plano de manejo e tratos silviculturais (desbrota); e,

iv) $\quad \mathrm{r}$ é a taxa de desconto.

Análises empíricas mostraram que uma taxa de juros de $5 \%$ é requerida para estudos de longo-prazo, que consideram décadas em florestas (Berck, 1979; Ricker \& Daly, 1998). Leslie (1987) sugere que a taxa de juros selecionada é um processo inteiramente subjetivo. No entanto, segundo Clark (1976) aumentando a taxa de juros de $6 \%$ para $10 \%$ pode-se observar uma redução significativa na rotação ótima. A escolha da taxa de juros deve levar em consideração a expectativa do proprietário da terra e os retornos que, normalmente, são esperados no uso da terra para o cultivo de culturas agrícolas tradicionais na região.

A curva de crescimento da caixeta será estimada por meio de uma regressão assintótica. A função escolhida foi a logística, definida por:

$$
f(\mathrm{X})=\frac{\alpha}{1+e^{-(\beta+\gamma \mathrm{X})}}
$$

Onde $\alpha, \beta$ e $\gamma$ são parâmetros $(\alpha>0$ e $\gamma>0)$. A partir dessa fórmula, pode-se obter:

$$
\begin{aligned}
& \frac{d}{d X} f(X)=\frac{\alpha \gamma e^{-(\beta+\gamma X)}}{\left[1+e^{-(\beta+\gamma X)}\right]}=\frac{\gamma}{\alpha} f(X)[\alpha-f(X)] \\
& \lim _{X \rightarrow \infty} f(X)=\alpha \\
& \lim _{X \rightarrow-\infty} f(X)=0
\end{aligned}
$$


Logo, verifica-se que a função logística é monotonicamente crescente e fica entre duas assíntotas horizontais que são os eixos das abcissas e a reta de ordenada constante e igual a $\alpha$ (Hoffmann, 1998). O parâmetro $\alpha$ é a distância entre duas assíntotas, denominado nível de saturação. O parâmetro $\gamma$ está relacionado com a taxa de crescimento da função, como pode ser observado na seguinte fórmula:

$$
\frac{d}{d \mathrm{X}}\left[\frac{f(\mathrm{X})}{\alpha}\right]=\gamma \frac{f(\mathrm{X})}{\alpha}\left[1-\frac{f(\mathrm{X})}{\alpha}\right]
$$

O parâmetro $\beta$ é indicador de posição, ou seja, mudando seu valor enquanto os outros são mantidos fixos, a curva irá se movimentar horizontalmente (Hoffmann, 1998). O uso da função logística para o estudo descritivo de crescimento de espécies, vegetais e animais, é baseado na equação diferencial (5), ou seja,

$$
\frac{d}{d \mathrm{X}} f(\mathrm{X})=\theta f(\mathrm{X})[\alpha-f(\mathrm{X})]
$$

Onde:

$$
\theta=\frac{\gamma}{\alpha} \text { é uma constante. }
$$

A equação (7) mostra que a taxa de crescimento da função logística é proporcional ao valor alcançado pela função e à diferença entre esse valor e o nível de saturação (Hoffmann, 1998). O valor do fator $f(\mathrm{X})$ cresce com $\mathrm{X}$, sendo denominado fator de momento. A diferença $\alpha-f(\mathrm{X})$ tem seu valor diminuído à medida que $\mathrm{X}$ aumenta, logo, é denominada fator de contenção (Hoffmann, 1998). 
De (7) temos

$$
\frac{1}{f(\mathrm{X})} \cdot \frac{d}{d \mathrm{X}} f(\mathrm{X})=\theta[\alpha-f(\mathrm{X})]
$$

Assim, pode-se observar que a taxa de crescimento relativo de $f(\mathrm{X})$ decresce linearmente com o aumento do valor de $f(\mathrm{X})$ (Hoffmann, 1998).

Estimativas consistentes e assintoticamente eficientes dos parâmetros $\alpha, \beta$ e $\gamma$ da função logística podem ser obtidas com o método descrito por Nelder $(1961)^{14}$. Entretanto, outra maneira de encontrar as estimativas preliminares desses parâmetros é por meio da determinação preliminar da estimativa do parâmetro $\alpha$. Para isso, deve-se a partir da equação (4) considerar a existência de um erro multiplicativo, o que irá fornecer o modelo

$$
Y i=\alpha\left[1+e^{-(\beta+\gamma X i)}\right]^{-1} \varepsilon i
$$

De acordo com (Hoffmann, 1998), é razoável pressupor que o erro é proporcional ao valor da variável (que é multiplicativo), quando a função logística é usada para analisar o crescimento de um organismo vivo. Pressupondo que o parâmetro $\alpha$ é conhecido, e desprezando o erro do modelo (9), temos:

$$
\ln \left[\frac{Y i}{(a-Y i)}\right]=\beta+\gamma X i
$$

Onde

i) i é o índice que representa o período de tempo;

ii) $\quad Y_{i}$ é o volume de madeira ( $\mathrm{em}^{3}$ por ha);

iii) $X_{i}$ é o período referente a coleta de dados após a realização da colheita; e,

\footnotetext{
${ }^{14}$ Esse método é descrito por Hoffmann (1998).
} 
iv) $\quad a$ é a estimativa preliminar do parâmetro $\alpha$ que representa o volume de madeira máximo esperado, $\mathrm{em}^{3}$ por hectare.

A equação (10) sugere que conhecida a estimativa preliminar de $\alpha$, as estimativas preliminares de $\beta$ e $\gamma$ podem ser obtidas ajustando um regressão linear simples de $\ln \left[\frac{Y i}{(\alpha-Y i)}\right]$ contra Xi (Hoffmann, 1998). 


\section{RESULTADOS E DISCUSSÃO}

\subsection{Caracterização da amostra}

\subsubsection{Proprietários de terra (caixetal)}

Dez proprietários de terra, ou seja, de áreas em que há caixetal foram entrevistados nos municípios de Iguape e Cananéia, na região do Vale do Ribeira. O tamanho das propriedades variou entre doze e doze mil alqueires (Tabela 5), e as áreas de caixetal, existentes dentro das propriedades, entre cinco e mil e quinhentos alqueires (Tabela 6).

Tabela 5. Número de propriedade por estrato de área total, em alqueires, na amostra.

\begin{tabular}{cc}
\hline Estrato de Área (Alq.) & Número de Ocorrências \\
\hline $0 \sim 50$ & 2 \\
$50 \sim 200$ & 4 \\
$>200$ & 4 \\
\hline
\end{tabular}

Fonte: Elaborada com base nos dados obtidos na pesquisa. 
Tabela 6. Número de caixetais por estrato de área de caixetal, em alqueires, na amostra.

\begin{tabular}{cc}
\hline Estrato de Área de caixetal (Alq.) & Número de Ocorrências \\
\hline $0 \sim 50$ & 7 \\
$50 \sim 200$ & 2 \\
$>200$ & 1 \\
\hline
\end{tabular}

Fonte: Elaborada com base nos dados obtidos na pesquisa.

O preço médio da terra estimado foi de $\mathrm{R} \$ 1.000,00$ por alqueire, o que corresponde a $\mathrm{R} \$ 413,22$ por hectare. No entanto, houve exceção para terras que se localizam próximas aos rios Peropava e Ribeira de Iguape. Estas áreas sofrem riscos de inundação, na época das chuvas, devido à abertura do Valo Grande. Conseqüentemente, o seu preço é cerca de metade do preço médio anterior. O Instituto de Economia Agrícola (IEA) estima, para o ano de 2001, que o preço médio da terra de cultura de primeira na região de Registro é de cerca de $\mathrm{R} \$ 1.882,05$ por hectare, com uma faixa de variação entre $\mathrm{R} \$ 1.239,67$ e $\mathrm{R}$ \$ 4.132,23 $\mathrm{ha}^{-1}$. No caso de terras de cultura de segunda, o valor médio fica em torno de $\mathrm{R} \$ 1.151,39 \mathrm{ha}^{-1}$. A faixa de variação nos preços para esse tipo de terra é de $\mathrm{R} \$ 826,45$ a $\mathrm{R} \$ 2.479,34 \mathrm{ha}^{-1}$. O preço médio das terras para pastagem foi estimado em $\mathrm{R} \$ 901,58 \mathrm{ha}^{-1}$, com variação entre $\mathrm{R} \$ 413,22$ e $\mathrm{R} \$ 2.479,34$ $\mathrm{ha}^{-1}$ (IEA, 2001). O preço médio de terras para reflorestamento foi estimado em $\mathrm{R} \$$ $688,02 \mathrm{ha}^{-1}$, com variação entre $\mathrm{R} \$ 247,93$ e $\mathrm{R} \$ 2.314,05 \mathrm{ha}^{-1}$ (IEA, 2001). As terras de campo têm o preço médio de $\mathrm{R} \$ 739,67 \mathrm{ha}^{-1}$, com variação entre $\mathrm{R}$ \$ 206,61 e R\$ $1.652,89 \mathrm{ha}^{-1}$ (IEA, 2001).

Dentre as diferentes categorias, as terras de reflorestamento são as de menor preço, o valor médio estimado é de cerca de $\mathrm{R} \$ 1.665,00$, por alqueire (IEA, 2001). Apesar disso, este valor é cerca $66,5 \%$ maior do que o preço médio encontrado na pesquisa de campo.

Assim, observa-se uma significativa variação entre os preços encontrados nesta pesquisa e os disponíveis em estatísticas oficiais. Esta variação pode ser explicada 
pelas diferentes categorias de terra nessas estatísticas. Além disso, deve-se ressaltar que as estatísticas oficiais referem-se a dados que abrangem toda a região do Escritório de Desenvolvimento Rural (EDR) de Registro.

Os proprietários amostrados, em sua maioria, usam suas terras apenas para o plantio de produtos para subsistência, como arroz, feijão, milho e legumes. O restante exerce atividades diferenciadas, como a criação de búfalos; o cultivo do maracujá, do inhame e a fabricação de farinha de mandioca; a piscicultura e a extração do palmito (Tabela 7).

Tabela 7. Distribuição das propriedades por atividade desenvolvida na amostra.

\begin{tabular}{lc}
\hline \multicolumn{1}{c}{ Atividades } & Número de Proprietários \\
\hline Búfalo & 2 \\
Piscicultura e extração de palmito & 1 \\
Plantio para subsistência & 6 \\
Maracujá, farinha de mandioca e inhame & 1 \\
\hline
\end{tabular}

Fonte: Elaborada com base nos dados obtidos na pesquisa.

Em grande parte das propriedades (60\%), nunca foi realizada a extração de caixeta. No restante das áreas visitadas, em dois casos o proprietário não se lembrava quando havia ocorrido a primeira extração. Em duas outras áreas a primeira extração ocorreu nos anos de 1982 e 2001. Do total de áreas em que a extração já ocorreu (4 propriedades), em três foi realizada apenas uma vez. Logo, em apenas uma propriedade houve mais de uma extração, a penúltima na década de 90 (ano de 1999) e a última no ano de 2001 (Tabela 8). Nas três áreas em que houve uma extração, apenas em um dos casos o plano de manejo foi seguido (ano de 2001) (Tabela 8). Nos casos restantes, o proprietário não se lembrava. Na área em que a extração ocorreu por mais de duas vezes, na penúltima (1999) e última (2001) extrações o plano de manejo foi realizado (Tabela 8). 
Tabela 8. Distribuição das propriedades por estrato de número de extrações total e com plano de manejo.

\begin{tabular}{ccc}
\hline Estrato de Extração & Número total de ocorrências & $\begin{array}{c}\text { Número de ocorrências com plano } \\
\text { de manejo }\end{array}$ \\
\hline Zero & 6 & - \\
1 & 3 & 1 \\
2 & 0 & - \\
$>2$ & 1 & 2 \\
\hline
\end{tabular}

Fonte: Elaborada com base nos dados obtidos na pesquisa.

Os proprietários acreditam que a existência das áreas de caixetais é importante para a manutenção e conservação da flora e da fauna da Mata Altântica. Em relação a quais motivos o levariam a converter a área de caixetal em outras alternativas de uso do solo, as respostas foram diferenciadas. Dentre elas destacam-se:

i) A terra não é propícia para o cultivo de atividades agrícolas;

ii) Não haveria motivo para a conversão se houvesse incentivo do governo de forma que a extração se tornasse viável economicamente;

iii) Usaria a área para a exploração do palmito, já que a conversão é muito difícil;

iv) Faria a conversão para o cultivo de arroz e banana, pois são mais rentáveis, há maior facilidade no manejo e possuem maior demanda; e,

v) A área não é propícia para o cultivo de atividades agrícolas e poderia ser mais rentável com a extração de ervas medicinais (Tabela 9). 
Tabela 9. Motivos para a conversão do solo dos caixetais e número de ocorrências.

\begin{tabular}{lc}
\hline \multicolumn{1}{c}{ Motivos } & Número de ocorrências \\
\hline Área não é propícia para o cultivo de atividades & 3 \\
agrícolas & 3 \\
Não há motivo para conversão desde que haja & 1 \\
incentivo do governo & 2 \\
Exploração do palmito & 1 \\
Cultivo de arroz e banana & \\
Extração de ervas medicinais & \\
\hline
\end{tabular}

Fonte: Elaborada com base nos dados obtidos na pesquisa.

De maneira geral, a maior parte dos entrevistados (80\%) acreditam que o manejo da caixeta é rentável, seja como fonte de renda ou apenas como complemento. Dentre estes, um acredita que a atividade é rentável desde que se tenha, na propriedade, a estrutura física necessária para o desdobramento da madeira em toras. O restante (20\%), acredita que a atividade não traz nenhum retorno financeiro (Tabela 10).

Tabela 10. Distribuição da percepção dos entrevistados em relação à rentabilidade da atividade extrativista.

\begin{tabular}{lc}
\hline \multicolumn{1}{c}{ Rentabilidade } & Número de ocorrências \\
\hline Boa (é rentável) & 3 \\
Regular (como complemento) & 4 \\
É rentável desde que o beneficiamento ocorra na & 1 \\
propriedade & 2 \\
Ruim (não é rentável) & \\
\hline
\end{tabular}

Fonte: Elaborada com base nos dados obtidos na pesquisa.

Os proprietários de terra foram questionados a respeito de qual deveria ser o valor da madeira de caixeta vendida "em pé", ou seja, da matagem, atualmente, 
para que o produtor se sentisse incentivado a manter a área de caixetal e a investir na atividade extrativista. As respostas variaram entre $\mathrm{R} \$ 60,00 \mathrm{mst}^{-1}$ e $\mathrm{R} \$ 120,00 \mathrm{mst}^{-1}$ (Tabela 11), sendo que, em média, o valor deveria ser de $\mathrm{R} \$ 82,00 \mathrm{mst}^{-1}$. O preço atual da "matagem", no Vale do Ribeira, varia entre $\mathrm{R} \$ 20,00 \mathrm{mst}^{-1}$ e 25,00 $\mathrm{mst}^{-1}$.

Tabela 11. Distribuição da amostra por estrato de valor da matagem (em R $\$$ ).

\begin{tabular}{cc}
\hline Valor da matagem & Número de ocorrências \\
\hline $60 \sim 80$ & 6 \\
$80 \sim 100$ & 3 \\
$>100$ & 1 \\
\hline
\end{tabular}

Fonte: Elaborada com base nos dados obtidos na pesquisa. 


\subsubsection{Caixeteiros}

Foram aplicados doze questionários com caixeteiros nos municípios de Iguape e Cananéia, na região do Vale do Ribeira, sendo nove homens e três mulheres. Logo, pode-se observar que a atividade, atualmente, não tem sido exercida exclusivamente por homens, como constatado por Diegues et al. (1991).

A maior parte dos caixeteiros entrevistados tem idade entre 30 e 50 anos, são casados e têm filhos (Tabela 12 e 13).

Tabela 12. Distribuição da amostra por estrato de idade.

\begin{tabular}{cc}
\hline Idade & Número de ocorrências \\
\hline $15 \sim 30$ & 4 \\
$30 \sim 45$ & 5 \\
$45 \sim 60$ & 2 \\
$>60$ & 1 \\
\hline
\end{tabular}

Fonte: Elaborada com base nos dados obtidos na pesquisa.

Tabela 13. Distribuição da composição familiar dos caixeteiros na amostra.

\begin{tabular}{lc}
\hline \multicolumn{1}{c}{ Composição familiar } & Número de ocorrências \\
\hline Casado com filhos & 5 \\
Casado sem filhos & 2 \\
Separado & 1 \\
Solteiro & 4 \\
\hline
\end{tabular}

Fonte: Elaborada com base nos dados obtidos na pesquisa. 
Os caixeteiros, em sua maioria, estudaram até a quarta-série do primeiro grau e/ou completaram o primeiro grau. Uma pequena parte não estudou e uma parte ainda menor possui o segundo grau completo (Tabela 14). Observou-se que o grau de escolaridade tem uma variação relativa parecida com certas características da composição familiar e com a idade: quanto mais jovem maior é sua escolaridade.

Tabela 14. Distribuição do grau de escolaridade dos caixeteiros na amostra.

\begin{tabular}{lc}
\hline \multicolumn{1}{c}{ Grau de escolaridade } & Número de ocorrências \\
\hline Quarta-série & 5 \\
Primeiro grau (completo) & 4 \\
Segundo grau (completo) & 1 \\
Não estudou & 2 \\
\hline
\end{tabular}

Fonte: Elaborada com base nos dados obtidos na pesquisa.

A atividade extrativista é, para a maioria dos entrevistados, a principal fonte de renda. Entretanto, os caixeteiros acabam exercendo outras atividades ("bicos") devido à extração da caixeta não ser uma atividade contínua durante o ano (Tabela 15). As atividades descritas como "bicos" compreendem: a pesca da manjuba; zelador (em sítios); e, qualquer outro tipo de alternativa de trabalho, geralmente, braçal, como ajudante na construção civil.

A periodicidade na extração foi explicada pelas chuvas, que podem comprometer o corte e a retirada da madeira do caixetal, e, também, devido a variações na demanda por madeira. Para caixeteiros que são proprietários de terra, a falta de dinheiro para investimento em serraria própria foi apontada como motivo que afeta a periodicidade da atividade. Isto ocorre devido à existência de dificuldades na negociação com compradores (como serrarias e oficinas de artesanato) (Tabela 16). 
Tabela 15. Distribuição das atividades exercidas pelos caixeteiros da amostra durante o ano.

\begin{tabular}{lc}
\hline \multicolumn{1}{c}{ Atividades } & Número de ocorrências \\
\hline Extração de caixeta & 2 \\
Extração de caixeta e administração rural & 1 \\
Extração de caixeta e pesca de manjuba & 1 \\
Extração de caixeta e "bicos" & 2 \\
Funcionário IBAMA & 1 \\
Extração de caixeta e cultivo agrícola de & 5 \\
subsistência & \\
\hline
\end{tabular}

Fonte: Elaborada com base nos dados obtidos na pesquisa.

Tabela 16. Motivos para a periodicidade na extração da caixeta e número de ocorrências.

\begin{tabular}{lc}
\hline \multicolumn{1}{c}{ Motivos } & Número de ocorrências \\
\hline Chuvas & 3 \\
Chuvas e falta de dinheiro para investir em serraria & 5 \\
própria & 3 \\
Demanda por madeira & 1 \\
Não motivo para variação & \\
\hline
\end{tabular}

Fonte: Elaborada com base nos dados obtidos na pesquisa.

Para caixeteiros, os principais problemas relativos à exploração e utilização da caixeta são:

i) Falta de demanda por madeira;

ii) Falta de compradores que, na maioria das vezes, preferem a madeira já beneficiada ou "aparelhada" (com medidas que diminuem o trabalho na indústria); 
iii) Preço baixo da madeira em toras;

iii) Rigor na fiscalização quanto ao cumprimento das exigências legais da atividade (plano de manejo);

iv) Riscos da atividade,

v) Dificuldades de comercialização devido à redução de compradores na última década; e,

i) Falta de entendimento entre caixeteiros e serraria-ACAX (Tabela 17).

Tabela 17. Número de ocorrência de relatos de problemas relativos à extração da caixeta na amostra.

\begin{tabular}{lc}
\hline \multicolumn{1}{c}{ Problemas } & Número de ocorrências \\
\hline Falta de demanda por madeira; & 11 \\
Preço baixo & 5 \\
Rigor na fiscalização & 5 \\
Dificuldades de comercialização & 1 \\
Falta de entendimento entre caixeteiros e & 1 \\
serraria-ACAX & 5 \\
Riscos da atividade & 5 \\
\hline
\end{tabular}

Fonte: Elaborada com base nos dados obtidos na pesquisa.

A oportunidade de trabalho pode surgir por meio de outro caixeteiro, que poderá ser o responsável em montar a equipe, ou por meio da serraria (compradores de madeira em toras, como artesãos e fábricas de calçado). O tipo de contrato feito com o proprietário da terra pode variar. Os caixeteiros entrevistados compunham três equipes: duas negociaram diretamente com o proprietário da terra, pagando-o pela matagem, em metro estere. A outra equipe é composta por caixeteiros que são proprietários de caixetal, que nesse caso, negociam diretamente com o comprador, sendo o comprador quem procura o "mato". 
Antes que ocorra a negociação entre proprietários de caixetal e compradores da madeira "em pé”, quer seja caixeteiros ou serrarias, é necessário que a área de caixetal em questão tenha o plano de manejo aprovado pelo DEPRN.

Todos os caixeteiros entrevistados trabalham em áreas de caixetal onde há plano de manejo, e afirmaram que o mesmo está sendo seguido conforme exigido por lei. Os caixeteiros que negociam o "mato" diretamente com proprietários de terra, vendem a madeira em toras (por metro estere) para as serrarias ou artesãos. Estes são os responsáveis pelo transporte das toras do "porto" ao local de destino para beneficiamento e processamento. Outra forma de negociação observada ocorre quando o caixeteiro vende a madeira em toras para fábricas, no caso específico para fábrica de artesanato, que serão responsáveis pelo beneficiamento, processamento e industrialização da madeira. Neste caso, a madeira em toras poderá ser entregue, pelo caixeteiro, no "porto" ou na própria fábrica, dependendo do tipo de contrato fechado entre caixeteiros e fábrica.

Do total (1.112 mst) de madeira em toras extraída, durante o ano de 2001, cerca de $72,3 \%$ foram usadas para a produção de artesanatos, $27 \%$ para a produção de salto para calçados e tamancos e $7 \%$ para amostra de tabuinhas (enviadas para o exterior pela serraria “O Casqueiro” de Paranaguá/PR) (Tabela 18).

A equipe de trabalho, normalmente, é composta por três indivíduos. Este número de componentes é, na maior parte das extrações (cerca de 67\%), fixo. A variação do número de componentes ocorre de acordo com as características da área. Cada caixetal possui características específicas, tanto em relação ao ambiente físico (vegetação) quanto ao tipo de madeira. Logo, nota-se que não há uma caracterização uniforme da atividade. 
Tabela 18. Tipo de produto a que as toras se destinam.

\begin{tabular}{lcc}
\hline & Tipo de produto & Número de ocorrências \\
\hline Artesanato & 3 \\
Calçado & 3 \\
Amostra & 5 \\
Lápis $^{*}$ & 1 \\
\hline
\end{tabular}

Fonte: Elaborada com base nos dados obtidos na pesquisa.

(*) Madeira extraída na década de 90, fazenda Cindumel município de Iguape/SP.

A equipe, em 92\% dos casos observados (onze caixeteiros), é composta por integrantes que possuem algum tipo de relação familiar de primeiro e segundo grau. Normalmente, as tarefas são pré-definidas entre os membros que compõe a equipe. No entanto, não existe diferença entre os salários. Foi observada a diferenciação apenas em uma equipe, que era composta por pai, filho e sobrinho. Esta diferenciação está relacionada à idade, ou seja, com o tempo de experiência na atividade e com o tipo de responsabilidade exercida no processo de corte e extração da madeira. Foi constatado que, geralmente, o caixeteiro mais velho (experiente) é o responsável pelo corte.

Duas equipes não possuem um tipo específico de pagamento, o valor recebido do comprador da madeira é dividido (em partes iguais) entre seus membros. Logo, está sujeito ao tipo de contrato feito entre o comprador da madeira e a equipe de caixeteiros. Em outra equipe, o pagamento dos salários é quinzenal e, também, está relacionado ao tipo de contrato realizado entre as duas partes.

O processo de corte e extração tem início com o conhecimento da área: o caixeteiro irá "abrir picada", ou seja, irá fazer a limpeza de cipós e trilhas, e verificar qual a melhor forma de cortar e transportar a madeira até o "porto". A próxima etapa será a de estivar, que implica na limpeza do caminho que será usado para a retirada da madeira do caixetal. Estando pronto o caminho de retirada da madeira, o próximo passo será o corte das árvores. O corte compreende as tarefas de seleção de árvores, derrubada e retalhação em toras. Após a retalhação, ocorrerá o transporte das toras ao "porto", onde 
ocorre o empilhamento, medição e o carregamento do caminhão que as levarão ao local de destino.

O transporte ou deslocamento da madeira até o "porto" pode ser realizado por uma série de operações, conforme a localização do caixetal. As equipes entrevistadas utilizam as seguintes formas de transporte:

i) trole $\rightarrow$ trator $\rightarrow$ "porto";

ii) trole $\rightarrow$ rio $\rightarrow$ trator $\rightarrow$ "porto";

iii) trole $\rightarrow$ barco $\rightarrow$ "porto"; e,

iv) braçal $\rightarrow$ trator $\rightarrow$ "porto".

No "porto" ocorre o carregamento, que consiste na colocação das toras empilhadas dentro do caminhão que as transportarão até o local de processamento comprador. Antigamente, nesta etapa, acontecia o refugo. No "porto", o comprador fazia uma seleção das toras que seriam úteis para o processamento primário, sendo o restante abandonado. Entretanto, atualmente, não se observa a existência de refugo; isto pode ser explicado devido ao fato de que antigamente as toras abandonadas pertenciam ao caixeteiro, mas hoje pertencem ao comprador da madeira. Logo, o desperdício de toras não tem ocorrido.

Dos resíduos florestais gerados na colheita da caixeta, apenas as toras são aproveitadas. Essas toras são usadas na construção de trilhas dentro da floresta. Como o terreno é alagado, a madeira é colocada sob o solo de forma a dar sustentação para que se possa caminhar com maior facilidade. Para grande parte dos caixeteiros entrevistados (75\%), o motivo do não aproveitamento dos resíduos é a falta de compradores para epífitas (bromélias), cipós e galhos. Para o restante dos entrevistados, todos os resíduos (considerando como resíduos apenas as toras impróprias para processamento) são aproveitados.

O preço da madeira em toras, negociado em metro estere, para a maioria dos entrevistados varia com certas características da madeira e do comprador. O preço é fixo apenas no caso de haver a existência de um único comprador. A característica da 
madeira, em toras, que faz com que variações no preço ocorram é a largura do diâmetro, madeiras mais finas valem menos. No caso do comprador, a variação ocorre pela falta de demanda: a existência de poucos compradores faz com que as exigências referentes ao fornecimento sejam mais rígidas. 


\subsubsection{Serrarias}

As serrarias são responsáveis pelo processamento da madeira em toras podendo, em alguns casos, também fabricarem produtos finais como artesanato, móveis, brinquedos e utensílios domésticos. As serrarias que se localizam na região do Vale do Ribeira que processam a madeira de caixeta, atualmente, são: Associação dos Jovens da Juréia (AJJ), localizada na Barra do Ribeira-Juréia; serraria JP da Silva localizada no município de Miracatu; e, Associação dos Caixeteiros (ACAX), em Iguape.

Foram aplicados questionários com os responsáveis pela administração dessas serrarias, abrangendo questões relativas a aspectos técnicos, operacionais, de negociação entre fornecedores (proprietários de terra e caixeteiros) e compradores, de comercialização, mercado e financeiro. As serrarias são diferenciadas em sua estrutura física e, portanto, de processamento da madeira. Logo, cada uma possui característica específica para as etapas envolvidas no processamento e comercialização.

A capacidade produtiva, em $\mathrm{m}^{3}$, mensal da marcenaria da AJJ é $04 \mathrm{~m}^{3}$. Ela utiliza, em seu processo produtivo, a madeira de caixeta e raízes de araçá e bambu. Produz peças de artesanato de variados tamanhos e para usos diversos, como utensílios domésticos (de decoração e de uso pessoal) e móveis, como mesa infantil e bancos.

A serraria JP da Silva possui uma capacidade produtiva mensal instalada de $20 \mathrm{~m}^{3}$. Utiliza para processamento as madeiras de caixeta, eucalipto, pinus e peroba. A madeira de caixeta é usada para a fabricação de tamancos, cabides e violões. Nesta serraria ocorre o processamento primário da madeira em toras, que recebe acabamento final nas indústrias.

A capacidade produtiva da serraria ACAX é $200 \mathrm{~m}^{3} / \mathrm{mês}$ (para produção de tabuinhas). As madeiras utilizadas são: caixeta, pinus e peroba. A caixeta é usada na produção de brinquedos, tamanco, artesanato e utensílios domésticos. Esta serraria fornece a madeira processada, em pranchas, e produtos acabados, como é o caso de brinquedos e utensílios domésticos.

O principal problema relativo à utilização da caixeta é diferente para cada uma das serrarias. No entanto, há um problema em comum: a falta de demanda por 
madeira processada e produtos finais feitos com caixeta. Para a AJJ, as dificuldades para a comercialização de seus produtos são: falta de mercado consumidor; e, a necessidade de equipamentos, em seu processo produtivo, como ferramentas manuais e elétricas.

A serraria JP da Silva informou que o principal problema em se trabalhar com a caixeta é devido a características da madeira que levam a rachaduras, nas toras e pranchas, dependendo da fase da lua em que a madeira é cortada e processada. Para a serraria da ACAX, os problemas são: falta de capital de giro para investimento em produtos; e, falta de compradores para a madeira processada e para produtos acabados.

O volume de madeira de caixeta processada durante o ano não sofre variação apenas na serraria JP da Silva, que utiliza cerca de 18 mst por mês ou cerca de 190 mst por ano, em seu processo produtivo (Tabela 19). Segundo a AJJ e a ACAX, a variação ocorre devido à demanda por produtos ser sazonal, como no caso de artesanatos e tamancos (Tabelas 20 e 21). Estes produtos têm maior procura em certas estações do ano, como verão. Nesta época, a região recebe uma quantidade maior de turistas devido a características da estação, que é habitualmente tida como período de férias e do calor.

Observa-se que o processamento da caixeta nos quatro trimestres do ano é diferenciado entre as serrarias, a serraria JP da Silva possui um processamento regular durante todo o ano. A AJJ, no primeiro trimestre, possui um processamento intenso; no segundo e terceiro, regular; e, no quarto intenso (Tabelas 19 e 20). Quanto à intensidade do processamento da caixeta durante o ano, em trimestres, da serraria da ACAX não podemos obter com precisão, pois a produção está quase parada. No ano de 2001 ocorreram apenas duas compras de madeira de caixeta, no primeiro e terceiro trimestres. 
Tabela 19. Volume de caixeta processada pela serraria JP da Silva em 2001, em mst.

\begin{tabular}{lccc}
\hline Período & Volume & Produto Final & Resíduo \\
\hline $01 / 2001$ & 18 & tamanco & Serragem e costaneira \\
$02 / 2001$ & 18 & tamanco & Serragem e costaneira \\
$03 / 2001$ & 18 & tamanco & Serragem e costaneira \\
$04 / 2001$ & 18 & tamanco & Serragem e costaneira \\
$05 / 2001$ & 18 & tamanco & Serragem e costaneira \\
$06 / 2001$ & 18 & tamanco & Serragem e costaneira \\
$07 / 2001$ & 18 & tamanco & Serragem e costaneira \\
$08 / 2001$ & 18 & tamanco & Serragem e costaneira \\
$09 / 2001$ & 18 & tamanco & Serragem e costaneira \\
$10 / 2001$ & 18 & tamanco & Serragem e costaneira \\
$11 / 2001$ & 18 & tamanco & Serragem e costaneira \\
Total & 198 & - & - \\
\hline
\end{tabular}

Fonte: Elaborada com base nos dados obtidos na pesquisa.

Tabela 20. Volume de caixeta processada pela serraria AJJ em 2001, em mst.

\begin{tabular}{lccc}
\hline Período & Volume & Produto & Resíduo \\
\hline $01 / 2001$ & 0 & Final & - \\
$02 / 2001$ & 0 & - & Serragem e aparas \\
$03 / 2001$ & 8 & artesanato & - \\
$04 / 2001$ & 0 & - & - \\
$05 / 2001$ & 0 & - & - \\
$06 / 2001$ & 0 & - & Serragem e aparas \\
$07 / 2001$ & 7 & artesanato & - \\
$08 / 2001$ & 0 & - & Serragem e aparas \\
$09 / 2001$ & 0 & - & - \\
$10 / 2001$ & 0 & artesanato & - \\
$11 / 2001$ & 9 & - & \\
Total & 24 & & \\
\hline
\end{tabular}

Fonte: Elaborada com base nos dados obtidos na pesquisa. 
Tabela 21. Volume de caixeta processada pela serraria ACAX em 2001, em mst.

\begin{tabular}{lccc}
\hline Período & Volume & $\begin{array}{c}\text { Produto } \\
\text { Final }\end{array}$ & Resíduo \\
\hline $01 / 2001$ & 0 & - & - \\
$02 / 2001$ & 0 & - & - \\
$03 / 2001$ & 11 & artesanato & Serragem e costaneira \\
$04 / 2001$ & 0 & - & - \\
$05 / 2001$ & 0 & - & - \\
$06 / 2001$ & 0 & - & - \\
$07 / 2001$ & 0 & - & - \\
$08 / 2001$ & 24 & tamanco & Serragem e costaneira \\
$09 / 2001$ & 0 & - & - \\
$10 / 2001$ & 0 & - & - \\
$11 / 2001$ & 0 & - & - \\
Total & 35 & & \\
\hline
\end{tabular}

Fonte: Elaborada com base nos dados obtidos na pesquisa.

Outra característica que diferencia as serrarias é o fato de os fornecedores da madeira de caixeta, em toras, não serem fixos para a AJJ e serraria da ACAX. As formas de negociação entre serraria e proprietário da terra (caixetal), e entre serraria e caixeteiros pode ocorrer de diferentes maneiras. Vários aspectos envolvem essas negociações, como características do caixetal e da madeira, e do produto a que as toras terão destino. Como citado anteriormente, as formas de negociação, entre caixeteiros e compradores, em relação ao custo de transporte da madeira em toras do "porto" ao local de processamento, variam de acordo com o comprador (serrarias, artesãos e fábricas).

A negociação entre a AJJ e o proprietário do caixetal ocorre através de arrendamento do caixetal com o caixeteiro, que é o responsável pela negociação feita com o proprietário e, portanto, pela matagem. Neste caso, a AJJ busca a madeira no "porto" e paga ao caixeteiro pela madeira em toras, em $\mathrm{R} \$ \mathrm{mst}^{-1}$.

No caso da serraria JP da Silva e ACAX, a negociação pode ocorrer de duas formas: a serraria pode negociar a matagem com o proprietário da terra (caixetal). 
Este empreita o "mato" para o caixeteiro, que corta a madeira e a leva até o "porto", local no qual a serraria irá buscá-la. A serraria também pode negociar a matagem com o proprietário do caixetal, ficando a serraria responsável em contratar o caixeteiro, que entrega a madeira no "porto". Nestes dois casos a serraria paga ao caixeteiro pela madeira em toras em $\mathrm{R} \$ \mathrm{mst}^{-1}$. Não existe contrato formal das negociações realizadas entre as serrarias, proprietários e caixeteiros. Todas as formas de negociações são feitas em $\mathrm{R} \$ \mathrm{mst}^{-1}$.

A serraria JP da Silva fornece a madeira de caixeta processada para indústrias de tamanco, cabides e violão. A ACAX fornece para indústrias, artesãos e lojas atacadistas. A AJJ fornece suas peças acabadas de artesanato para uma loja própria que possui, em consignação, para a SOS Mata Atlântica e em eventos locais e regionais. A ACAX fornece seus produtos finais para artesãos e lojas atacadistas.

A comercialização da madeira processada ocorre de forma diferenciada entre as serrarias. A ACAX fornece a madeira de acordo com o pedido, podendo ser em forma de sarrafo, pranchão ou de produto meio acabado, todos negociados em $\mathrm{m}^{3}$. O transporte pode ser responsabilidade da serraria ou do comprador. A serraria JP da Silva fornece pranchas negociadas em $\mathrm{m}^{3}$, o transporte é feito pela própria serraria.

Para a AJJ e ACAX, as perspectivas de mercado, ou seja, de aumento da demanda para artesanatos e brinquedos feitos com caixeta é boa. Para lápis se diferenciam: a ACAX acredita que as perspectivas são boas; e, para a JP da Silva, não há perspectivas para este produto, porém acredita que para tamanco e salto para calçado são excelentes. Para a ACAX as perspectivas são boas na fabricação de tamancos/saltos para calçados e utensílios domésticos.

O processamento primário da caixeta para tamancos ou saltos para calçados, na serraria JP da Silva, ocorre da seguinte forma: a madeira em toras é colocada na serra fita, que desdobra as toras em pranchas com $10 \mathrm{~cm}$ de altura. A serraria da ACAX possui outro procedimento: a madeira em toras é colocada na serra fita, que desdobra as toras grandes por meio de corte transversal e depois é usado a desdobradeira, que consiste na retirada de costaneiras, saindo pranchas que serão usadas na fabricação de tamancos (Figura 14). 
No caso do processamento primário da caixeta para artesanato, a AJJ possui os seguintes procedimentos: a madeira em toras é colocada na plaina, que desdobra toras finas; depois é usada a serra circular, que tira pranchas; no caso de ficar relevos, as pranchas voltam para a plaina, se não, a prancha é colocada no molde, onde o desenho, geralmente, em forma de peixe ou pássaro, é feito. Depois de feito o desenho, é usado o tico-tico e/ou a serra fita, que corta o desenho contornando-o. O próximo passo será a lixadeira e/ou facão e canivete, dependendo da necessidade do acabamento. $\mathrm{O}$ produto final é obtido com a pintura (Figura 15).

A serraria da ACAX utiliza operações diferenciadas da AJJ no processamento da madeira para artesanato. Em um primeiro momento as toras são colocadas no serrão, que desdobra toras finas; depois é usada a desdobradeira; refiladeira, que desdobra as pranchas, saindo sarrafos na medida desejada; desengrossadeira e, em último lugar, a lixadeira, no caso da necessidade de acabamento.

O processamento da madeira de caixeta para tabuinhas, usadas na industrialização de lápis, não tem ocorrido em nenhuma das serrarias visitadas. As operações existentes no processamento para tabuinhas compreendem cinco etapas. A primeira consiste na avaliação da largura do diâmetro das toras; depois as toras são passadas na desdobradeira; em seguida, é feita uma seleção das tabuinhas que deverão ir para a reguladora de largura e, depois, para a embalagem. As tabuinhas podem, em alguns casos, passar da etapa de seleção para a de embalagem (Figura 13).

As informações relativas à geração de resíduos madeireiros nos diferentes tipos de processamento primário da caixeta para artesanato e tamanco, são diferentes em cada uma das serrarias analisadas. No caso em que as toras são usadas na produção de artesanatos, os resíduos encontrados foram: sepilho (tipo de serragem mais grossa) e serragem, AJJ; costaneira e serragem, ACAX. Para tamanco: costaneira e serragem, ACAX; madeira para carvão, costaneira e serragem, serraria JP da Silva (Tabela 22). As quantidades de resíduos gerados no processamento primário de acordo com o produto a que as toras se destinam foi uma questão não respondida pelas serrarias. Este é um ponto do processo produtivo que não é valorizado e avaliado. 
Tabela 22. Tipos de resíduos madeireros gerados no processamento primário da caixeta na produção de artesanato e tamanco pelas serrarias AJJ, JP da Silva e ACAX.

\begin{tabular}{cccc}
\hline Produto & AJJ & ACAX & Serraria JP da Silva \\
\hline Artesanato & Sepilho e serragem & Costaneira e serragem & - \\
Tamanco & - & Costaneira e serragem & $\begin{array}{c}\text { Madeira para carvão, } \\
\text { costaneira e serragem }\end{array}$ \\
\hline
\end{tabular}

Fonte: Elaborada com base nos dados obtidos na pesquisa.

Segundo a ACAX, 25\% das toras se transformam em resíduo na forma de costaneiras, no processamento para artesanato, e $25 \%$ em serragem. Estas quantidades são as mesmas para o caso do uso da madeira para produção de tamancos ou salto para calçado. Para a AJJ, que produz artesanatos, são gerados: $10 \%$ de resíduo madeireiro na forma de serragem; e, $20 \%$ na forma de sepilho. Na serraria JP da Silva, cerca de 35\% das toras se transformam em madeira quebrada que são usadas para carvão.

O preço da madeira em toras não é fixo, podendo sofrer alterações devido a certas características da madeira (AJJ e JP da Silva) e do fornecedor (AJJ e ACAX). As variações no preço podem ocorrer devido a características no diâmetro (AJJ e serraria JP da Silva), de tortuosidade (AJJ) e devido à forma de negociação (ACAX) (Tabela 23).

De acordo com a serraria JP da Silva, a madeira de caixeta em toras, com diâmetro > $15 \mathrm{~cm}$, tem seu preço estabelecido em R \$ 50,00/mst (em dezembro de 2001). A madeira em toras, com diâmetro $<15 \mathrm{~cm}$, tem seu preço estabelecido na faixa de $\mathrm{R} \$$ 25,00/mst (AJJ).

A ACAX fornece madeira processada, $\mathrm{em}^{3}$, em qualquer formato por $\mathrm{R} \$ 450,00 / \mathrm{m}^{3}$. A serraria JP da Silva fornece a madeira serrada em pranchas com $10 \mathrm{~cm}$ de altura para indústrias de tamanco a $\mathrm{R} \$ 250,00 / \mathrm{m}^{3}$. 
Tabela 23. Motivos que causam a variação no preço da madeira em toras para as serrarias AJJ, ACAX e JP da Silva.

\begin{tabular}{cc}
\hline Serrarias & Motivos \\
\hline AJJ & Características da madeira - tortuosidade e largura do diâmetro \\
& Forma de negociação feita com fornecedor \\
ACAX & Forma de negociação feita com fornecedor \\
JP da Silva & Características da madeira - largura do diâmetro \\
\hline
\end{tabular}

Fonte: Elaborada com base nos dados obtidos na pesquisa.

Outro ponto observado foi em relação aos substitutos da caixeta. Segundo a AJJ não há substitutos para a caixeta, já que a caixeta possui as características essenciais para a produção de artesanato. O substituto apontado pela serraria JP da Silva foi o marupá, madeira conhecida como caixetão. Para a serraria da ACAX existem quatro substitutos, que são: gmelina, álamo, marupá e pinus.

Segundo as serrarias JP da Silva e ACAX, a madeira da caixeta é ideal para a produção de tabuinhas para lápis, sendo o marupá (caixetão) considerado como madeira de boa qualidade, ou seja, substitui a ideal. Gmelina e álamo são espécies de boa qualidade (ACAX). O pinus foi considerado como madeira não possuidora das qualidades exigidas pelo produto por ambas as serrarias.

A caixeta foi considerada como ideal para a produção de tamancos e saltos para calçado. O marupá como madeira de boa qualidade. A gmelina e o álamo como boa, pela ACAX, e o pinus como não possuidor das qualidades exigidas. Pode-se observar que a qualidade da madeira de caixeta e de seus substitutos é idêntica para a produção de lápis e tamanco de acordo com as serrarias JP da Silva e ACAX.

Para a produção de artesanatos a caixeta foi considerada como ideal pelas três serrarias. O marupá, a gmelina, o álamo e o pinus foram considerados como não possuidores das qualidades exigidas pela AJJ e pela serraria JP da Silva. Para a produção de brinquedos a caixeta é uma madeira de qualidade ideal, segundo a serraria da ACAX, o marupá e a gmelina de boa qualidade e o pinus como não possuidor das qualidades 
exigidas. A qualidade da madeira de álamo na produção de brinquedos não é conhecida por nenhuma das serrarias entrevistadas.

\subsection{Análise econômica}

\subsubsection{Proprietários de terra}

$\mathrm{O}$ estudo analisa a rentabilidade dos caixetais para os proprietários de terra da região do Vale do Ribeira-SP. Para efeito de comparação, dois cenários foram escolhidos. O primeiro avalia o retorno econômico obtido pelo proprietário da terra no caso da venda do "mato em pé" para o caixeteiro e/ou outro comprador da madeira. O outro cenário avalia a rentabilidade da atividade para proprietários de terra que também são caixeteiros. A diferença entre as duas formas de exploração reflete no valor da matagem e nos custos de colheita.

Os dados da pesquisa mostram que, para o primeiro caso, o proprietário recebe entre $\mathrm{R} \$ 20,00$ e 25,00 por metro estere de madeira "em pé". Os proprietários que também são caixeteiros, vendem a madeira em toras posta no "porto" por cerca de R\$ 35,00 por metro estere.

Em função das variabilidades das características biológicas da caixeta, principalmente por não existir homogeneidade na produção (volume de madeira por hectare), cinco cenários foram escolhidos. No primeiro, áreas com $20 \mathrm{mst}$ de madeira por hectare; no segundo, áreas com $30 \mathrm{mst} \mathrm{ha}^{-1}$; no terceiro, áreas com $40 \mathrm{mst} \mathrm{ha}^{-1}$; no quarto, áreas com $60 \mathrm{mst} \mathrm{ha}^{-1}$; e, finalmente, o quinto cenário considera $110 \mathrm{mst} \mathrm{ha}^{-1}$.

A rentabilidade para os cenários analisados para o preço da madeira "em pé” igual a $\mathrm{R} \$ 20,00 \mathrm{mst}^{-1}$ podem ser observadas na tabela 24 . Os valores encontrados variam entre $\mathrm{R} \$ 270,00 \mathrm{ha}^{-1}$ (20 mst/ha) e $\mathrm{R} \$ 2.068,00 \mathrm{ha}^{-1}$ (110 mst/ha), havendo uma diferença de cerca 7,6 vezes entre eles. Áreas com produtividade média, ou seja, 40 e 60 
mst/ha, têm sua rentabilidade estimada em R\$ 670,00 ha e R\$ 1.068,00 ha-1, respectivamente. Neste caso, a diferença relativa entre eles fica em torno de $60 \%$.

Tabela 24. Margem Bruta do manejo da caixeta para proprietários de terra, região do Vale do Ribeira-SP, em R \$ por mst e R \$ por ha. Valor da matagem estimado em R $\$ 20,00 / m s t$.

\begin{tabular}{lrrrrr}
\hline Itens & $20 \mathrm{mst} / \mathrm{ha}$ & $30 \mathrm{mst} / \mathrm{ha}$ & $40 \mathrm{mst} / \mathrm{ha}$ & $60 \mathrm{mst} / \mathrm{ha}$ & $110 \mathrm{mst} / \mathrm{ha}$ \\
\hline Custos & & & & & \\
Plano de manejo $^{1}(\mathrm{R} \$ / \mathrm{mst})$ & 5,00 & 3,33 & 2,50 & 1,67 & 0,91 \\
Tratos silviculturais $(\mathrm{R} \$ \mathrm{mst})^{\text {Margem Bruta }(\mathrm{R} \$ \mathrm{mst})}$ & 1,50 & 1,00 & 0,75 & 0,50 & 0,27 \\
Margem Bruta $(\mathrm{R} \$ / \mathrm{ha})$ & 13,50 & 15,67 & 16,75 & 17,83 & 18,82 \\
\hline
\end{tabular}

Fonte: Dados da pesquisa

1 Considerando que o custo do plano de manejo é de $\mathrm{R} \$ 100,00 \mathrm{ha}^{-1}$ (incluindo valores pagos ao mateiro, técnico florestal e engenheiro, transporte e encargos sociais).

${ }^{2}$ Considerando diária de $\mathrm{R} \$ 15,00$ e que duas pessoas/dia realizam o trabalho necessário em um hectare de caixetal.

Para os proprietários de terra que vendem a madeira "em pé" por $\mathrm{R} \$$ 25,00/mst, a menor rentabilidade verificada foi estimada em R \$370,00 ha ${ }^{-1}$ (Tabela 25). Este valor é cerca de 1,37 vezes maior que o encontrado para o preço de $\mathrm{R} \$ 20,00 \mathrm{mst}^{-1}$. A maior rentabilidade foi estimada em $\mathrm{R} \$ 2.620,00 \mathrm{ha}^{-1}$. Considerando a produtividade média de $40 \mathrm{mst} / \mathrm{ha}$, com rentabilidade em torno de $\mathrm{R} \$ 870,00 \mathrm{ha}^{-1}$, a diferença entre a rentabilidade desta área e de uma área com alto aproveitamento (110 mst/ha) é de 3,0 vezes.

De acordo com informação obtida na pesquisa com caixeteiros o tamanho médio das áreas de caixetais, na região de estudo, está em torno de 40 e $60 \mathrm{mst} \mathrm{ha}^{-1}$.

Os proprietários de terra que vendem a madeira em toras posta no "porto", além dos custos com plano de manejo e tratos silviculturais, têm acrescidos às suas despesas os custos da colheita (transporte casa-caixetal, combustível-motosserra, manutenção de equipamentos, depreciação e reposição de equipamentos e alimentação). 
Tabela 25. Margem Bruta do manejo da caixeta para proprietários de terra, região do Vale do Ribeira-SP, em R \$ por mst e R\$ por ha. Valor da matagem estimado em R $\$ 25,00 / m s t$.

\begin{tabular}{lrrrrr}
\hline \multicolumn{1}{c}{ Itens (receitas e custos) } & $20 \mathrm{mst} / \mathrm{ha}$ & $30 \mathrm{mst} / \mathrm{ha}$ & $40 \mathrm{mst} / \mathrm{ha}$ & $60 \mathrm{mst} / \mathrm{ha}$ & $110 \mathrm{mst} / \mathrm{ha}$ \\
\hline Custos & & & & & \\
Plano de manejo (R\$/mst) & 5,00 & 3,33 & 2,50 & 1,67 & 0,91 \\
Tratos silviculturais (R $/ \mathrm{mst})$ & 1,50 & 1,00 & 0,75 & 0,50 & 0,27 \\
Margem Bruta (R $\$ \mathrm{mst})$ & 18,50 & 20,67 & 21.75 & 22,83 & 23,82 \\
Margem Bruta (R $/ \mathrm{ha})$ & 370,00 & 620,00 & 870,00 & 1370,00 & 2620,00 \\
\hline
\end{tabular}

Fonte: Dados da pesquisa

A análise da rentabilidade para esses proprietários levou em consideração a variação em características ecológicas, logísticas e do solo da floresta. Estas características influenciam na produtividade do trabalho na colheita da madeira. Observa-se, na pesquisa de campo realizada com caixeteiros, que existem dois tipos de florestas: as que são de fácil acesso, cuja produtividade é de cerca de $7 \mathrm{mst} /$ equipe/dia para corte, retalhação e transporte da madeira até o "porto"; e, as áreas de difícil acesso, cuja produtividade está em torno de $5 \mathrm{mst} /$ equipe/dia.

A análise da rentabilidade para áreas com alta produtividade (7 mst/equipe/dia) e baixa produtividade (5 mst/equipe/dia), para os cinco cenários considerados, podem ser observadas nas tabelas 26 à 30. Para áreas com alta produtividade, a menor rentabilidade foi estimada em $\mathrm{R} \$ 465,15 \mathrm{ha}^{-1}$, e a maior em $\mathrm{R} \$$ 3.143,00 $\mathrm{ha}^{-1}$. Assim, existe uma diferença de cerca 7,0 vezes entre esses dois valores. Situação semelhante ocorre para áreas com baixa produtividade, com menor valor estimado em $\mathrm{R} \$ 427,40 \mathrm{ha}^{-1}$ e maior em $\mathrm{R} \$ 2.935,60 \mathrm{ha}^{-1}$.

Analisando a diferença relativa entre a rentabilidade estimada para áreas com alta e baixa produtividades, para os cenários considerados, nota-se que as áreas com alta produtividade geram uma rentabilidade cerca de 1,0 vez maior. 
Tabela 26. Margem Bruta do manejo da caixeta para proprietários de terra que são caixeteiros, região do Vale do Ribeira-SP, em R\$ por mst e R \$ por ha. Aproveitamento: 20 mst por ha.

\begin{tabular}{lrr}
\hline Itens & Área fácil (7mst/dia) & Área difícil (5mst/dia) \\
\hline Custos & & \\
Plano de manejo $^{1}(\mathrm{R} \$ / \mathrm{mst})$ & 5,00 & 5,00 \\
Tratos silviculturais $^{2}(\mathrm{R} \$ / \mathrm{mst})$ & 1,50 & 1,50 \\
Transporte casa-caixetal $^{3}(\mathrm{R} \$ / \mathrm{mst})$ & 1,93 & 2,70 \\
Combustível (motosserra) $^{4}(\mathrm{R} \$ / \mathrm{mst})$ & 0,53 & 0,53 \\
Manutenção de equipamentos $^{5}(\mathrm{R} \$ / \mathrm{mst})$ & 0,51 & 0,71 \\
Depreciação de equipamentos $^{6}(\mathrm{R} \$ / \mathrm{mst})$ & 0,07 & 0,10 \\
Reposição de equipamentos $^{7}(\mathrm{R} \$ / \mathrm{mst})$ & 0,06 & 0,09 \\
Alimentação $^{8}(\mathrm{R} \$ / \mathrm{mst})$ & 2,14 & 3,00 \\
Margem Bruta $^{\mathrm{R} \$ / \mathrm{mst})}$ & 23,26 & 21,37 \\
Margem Bruta $(\mathrm{R} \$ \mathrm{ha})$ & 465,13 & 427,38 \\
\hline
\end{tabular}

\section{Fonte: Dados da pesquisa}

1 Considerando que o custo do plano de manejo é de $\mathrm{R} \$ 100,00 \mathrm{ha}^{-1}$ (incluindo valores pagos ao mateiro, técnico florestal e engenheiro, transporte e encargos sociais).

${ }^{2}$ Considerando diária de $\mathrm{R} \$ 15,00$ e que duas pessoas/dia realizam o trabalho necessário em um hectare de caixetal.

${ }^{3}$ Considerando distância de $20 \mathrm{~km}$ e um veículo que consome $8 \mathrm{~km} /$ litro. Distância total: 40km/dia. Consumo total de combustível: 5 litros. Supondo que o litro do combustível seja R $\$ 1,80$.

${ }^{4}$ Considerando que uma motossera corta $4 \mathrm{mst} / \mathrm{dia}$ por litro de combustível consumido, sendo R $\$ 1,80 /$ litro. Ainda foi considerado o gasto com óleo, uma motosserra corta 16 mst/dia por litro de óleo consumido, sendo R \$ 1.20/litro.

${ }^{5}$ Considerando que o valor da manutenção (mensal) é $10 \%$ sobre o valor de uma motosserra nova ( R\$ 714,00), e que 20 dias /mês são trabalhados.

${ }^{6}$ Consirando valor inicial de uma motosserra: $\mathrm{R} \$ 714,00$; valor final como zero; e, vida útil de 7 anos (informação obtida em pesquisa). Supondo que 10 meses/ano e 20 dias/mês, são trabalhados.

7 Considerando: 1 machado ( $\mathrm{R} \$ 15,00 /$ unidade) e 3 foices (R\$ 10,00/unidade), com vida útil de seis meses. 200 dias/ano trabalhados.

${ }^{8}$ Considerando que cada equipe tem o custo diário de R $\$ 15,00$ com alimentação. 
Tabela 27. Margem Bruta do manejo da caixeta para proprietários de terra que são caixeteiros, região do Vale do Ribeira-SP, em R $\$$ por mst e R \$ por ha. Aproveitamento: $30 \mathrm{mst}$ por ha.

\begin{tabular}{lrr}
\hline \multicolumn{1}{c}{ Itens } & Área fácil (7mst/dia) & Área difícil (5mst/dia) \\
\hline Custos & 3,33 & 3,33 \\
Plano de manejo (R $\$ / \mathrm{mst})$ & 1,00 & 1,00 \\
Tratos silviculturais $(\mathrm{R} \$ / \mathrm{mst})$ & 1,93 & 2,70 \\
Transporte casa-caixetal $(\mathrm{R} \$ / \mathrm{mst})$ & 0,53 & 0,53 \\
Combustível (motosserra) $(\mathrm{R} \$ / \mathrm{mst})$ & 0,51 & 0,71 \\
Manutenção de equipamentos $(\mathrm{R} \$ / \mathrm{mst})$ & 0,07 & 0,10 \\
Depreciação de equipamentos $(\mathrm{R} \$ / \mathrm{mst})$ & 0,06 & 0,09 \\
Reposição de equipamentos $(\mathrm{R} \$ / \mathrm{mst})$ & 2,14 & 3,00 \\
Alimentação $(\mathrm{R} \$ / \mathrm{mst})$ & 25,42 & 23,54 \\
Margem Bruta $(\mathrm{R} \$ / \mathrm{mst})$ & 726,60 & 706,20 \\
Margem Bruta $(\mathrm{R} \$ / \mathrm{ha})$ & &
\end{tabular}

Fonte: Dados da pesquisa

Tabela 28. Margem Bruta do manejo da caixeta para proprietários de terra que são caixeteiros, região do Vale do Ribeira-SP, em R \$ por mst e R \$ por ha. Aproveitamento: $40 \mathrm{mst}$ por ha.

\begin{tabular}{|c|c|c|}
\hline Itens & Área fácil (7mst/dia) & Área difícil (5mst/dia) \\
\hline \multicolumn{3}{|l|}{ Custos } \\
\hline Plano de manejo (R $\$ / \mathrm{mst})$ & 2,50 & 2,50 \\
\hline Tratos silviculturais (R $\$ / m s t)$ & 0,75 & 0,75 \\
\hline Transporte casa-caixetal ( $\mathrm{R} \$ / \mathrm{mst})$ & 1,93 & 2,70 \\
\hline Combustível (motosserra) (R $\$ / m s t)$ & 0,53 & 0,53 \\
\hline Manutenção de equipamentos (R $\$ / m s t)$ & 0,51 & 0,71 \\
\hline Depreciação de equipamentos (R $\$ / m s t)$ & 0,07 & 0,10 \\
\hline Reposição de equipamentos (R $\$ / m s t)$ & 0,06 & 0,09 \\
\hline Alimentação (R\$/mst) & 2,14 & 3,00 \\
\hline Margem Bruta (R $\$ / m s t)$ & 26,51 & 24,62 \\
\hline Margem Bruta (R\$/ha) & 1060,26 & 984,76 \\
\hline
\end{tabular}

Fonte: Dados da pesquisa 
Tabela 29. Margem Bruta do manejo da caixeta para proprietários de terra que são caixeteiros, região do Vale do Ribeira-SP, em R $\$$ por mst e R \$ por ha. Aproveitamento: $60 \mathrm{mst}$ por ha.

\begin{tabular}{lrr}
\hline Itens & Área fácil (7mst/dia) & Área difícil (5mst/dia) \\
\hline Custos & & \\
Plano de manejo (R\$/mst) & 1,67 & 1,67 \\
Tratos silviculturais $(\mathrm{R} \$ / \mathrm{mst})$ & 0,50 & 0,50 \\
Transporte casa-caixetal (R $\$ / \mathrm{mst})$ & 1,93 & 2,70 \\
Combustível (motosserra) (R $\$ / \mathrm{mst})$ & 0,53 & 0,53 \\
Manutenção de equipamentos $(\mathrm{R} \$ / \mathrm{mst})$ & 0,51 & 0,71 \\
Depreciação de equipamentos $(\mathrm{R} \$ / \mathrm{mst})$ & 0,07 & 0,10 \\
Reposição de equipamentos $(\mathrm{R} \$ / \mathrm{mst})$ & 0,06 & 0,09 \\
Alimentação $(\mathrm{R} \$ / \mathrm{mst})$ & 2,14 & 3,00 \\
Margem Bruta $(\mathrm{R} \$ / \mathrm{mst})$ & 27,59 & 25,70 \\
Margem Bruta $(\mathrm{R} \$ / \mathrm{ha})$ & 1655,39 & 1542,14 \\
\hline
\end{tabular}

Fonte: Dados da pesquisa

Tabela 30. Margem Bruta do manejo da caixeta para proprietários de terra que são caixeteiros, região do Vale do Ribeira-SP, em R\$ por mst e R \$ por ha. Aproveitamento: 110 mst por ha.

\begin{tabular}{|c|c|c|}
\hline Itens & Área fácil (7mst/dia) & Área difícil (5mst/dia) \\
\hline \multicolumn{3}{|l|}{$\overline{\text { Custos }}$} \\
\hline Plano de manejo (R $\$ / m s t)$ & 0,91 & 0,91 \\
\hline Tratos silviculturais ( $\mathrm{R} \$ / \mathrm{mst})$ & 0,27 & 0,27 \\
\hline Transporte casa-caixetal ( $\mathrm{R} \$ / \mathrm{mst})$ & 1,93 & 2,70 \\
\hline Combustível (motosserra) (R $\$ / m s t)$ & 0,53 & 0,53 \\
\hline Manutenção de equipamentos (R \$/mst) & 0,51 & 0,71 \\
\hline Depreciação de equipamentos ( $\mathrm{R} \$ / \mathrm{mst})$ & 0,07 & 0,10 \\
\hline Reposição de equipamentos (R $\$ / m s t)$ & 0,06 & 0,09 \\
\hline Alimentação (R\$/mst) & 2,14 & 3,00 \\
\hline Margem Bruta (R\$/mst) & 28,57 & 26,69 \\
\hline Margem Bruta (R $\$ / h a)$ & 3143,21 & 2935,59 \\
\hline
\end{tabular}

Fonte: Dados da pesquisa 


\subsubsection{Caixeteiros}

Existem várias formas de negociação da madeira "em pé" entre proprietários, caixeteiros e/ou serrarias e fábricas, na região estudada. Assim, uma das opções existentes foi selecionada para a análise da rentabilidade do manejo da caixeta para esse agente. A receita dos caixeteiros consiste no valor recebido pela venda da madeira em toras posta no "porto". Seus custos são divididos em despesas com matagem e com a colheita (transporte casa-caixetal, combustível-motosserra, manutenção de equipamentos, depreciação e reposição de equipamentos e alimentação).

Como já mencionado, a variação na produtividade, de acordo com as características do caixetal, está diretamente relacionada a rentabilidade da atividade. Logo, para a análise dos caixeteiros, esse requisito será considerado. O valor considerado como recebido por caixeteiros pela madeira posta no "porto" foi de $\mathrm{R} \$$ 45,00 por mst, e o valor pago pela matagem de $\mathrm{R} \$ 20,00 \mathrm{mst}^{-1}$ (Tabela 31).

A margem bruta encontrada para os caixeteiros foi de $\mathrm{R} \$ 19,76$ por mst (para áreas de alta produtividade), e $\mathrm{R} \$ 17,87 \mathrm{mst}^{-1}$ para áreas de baixa produtividade (Tabela 5.27). Assim, a rentabilidade diária por equipe é de cerca R \$138,30 (para áreas com alta produtividade) e $\mathrm{R} \$ 89,35$ para áreas de difícil acesso.

Considerando uma média de 20 dias de trabalho por mês, temos: 140 mst de madeira colhida, para áreas de fácil acesso; e, 100 mst para as áreas de difícil acesso. No primeiro caso têm-se uma receita mensal por equipe de $\mathrm{R} \$ 2.766,40$ e, portanto, de $\mathrm{R} \$ 922,10$ por pessoa (para uma equipe de 3 indivíduos). Para a colheita em áreas de baixa produtividade têm-se a receita mensal por equipe de $R \$ 1.787,00$, e individual na faixa de $\mathrm{R} \$ 595,67$.

As receitas mensais obtidas, por equipe e individual, se comparadas às alternativas de trabalho existentes na região, apresentam-se como interessante fonte de trabalho e renda. Dados da pesquisa mostram que a renda obtida pelos caixeteiros com outras atividades fica entre 1,5 e 2,5 salários mínimos. Este fato explica o porque do interesse dos caixeteiros em manter esta atividade. Conforme verificado na pesquisa o 
manejo da caixeta é a mais rentável dentre as alternativas existentes (pesca, turismo e "bicos").

Tabela 31. Receitas e Despesas do manejo da caixeta para caixeteiros, região do Vale do Ribeira-SP, em R\$ por mst.

\begin{tabular}{lrr}
\hline Itens & Área fácil (7mst/dia) & Área difícil (5mst/dia) \\
\hline Receitas & & \\
Madeira em toras posta no "porto" & 45,00 & 45,00 \\
Custos & & \\
Matagem & 20,00 & 20,00 \\
Transporte casa-caixetal & 1,93 & 2,70 \\
Combustível (motosserra) & 0,53 & 0,53 \\
Manutenção de equipamentos & 0,51 & 0,71 \\
Depreciação de equipamentos & 0,07 & 0,10 \\
Reposição de equipamentos & 0,06 & 0,09 \\
Alimentação & 2,14 & 3,00 \\
Margem Bruta & 19,76 & 17,87 \\
\hline
\end{tabular}

Fonte: Dados da pesquisa

\subsubsection{Estimativa da rentabilidade da bananicultura na região de estudo}

Para verificar se o proprietário da terra possui incentivo econômico para a preservação dos caixetais, este estudo faz uma comparação da sua rentabilidade com a cultura da banana. A banana é uma das principais culturas agrícolas da região. As áreas de caixetais são propícias para o cultivo dessa planta devido a característica argilosa, sendo conhecidas como várzea.

Os dados referentes ao cultivo da banana foram obtidos com a Coordenadoria de Assistência Técnica e Integral (CATI) do município de Registro. A análise financeira a seguir mostra o retorno da cultura da banana nanica em um período de vinte anos. 
De acordo com os dados coletados, a produtividade da banana é crescente: no primeiro ano fica em cerca de 17,4 toneladas por ha; no segundo, em 34,8 t $\mathrm{ha}^{-1}$; no terceiro, 45,0 $\mathrm{t} \mathrm{ha}^{-1}$; e, se estabiliza em $50 \mathrm{t} \mathrm{ha}^{-1}$ no quarto e quinto anos. A cada cinco anos faz-se renovação da plantação.

Em condições climáticas favoráveis e sem a presença de pragas e doenças, o aproveitamento da produção anual fica entre 90\% e 95\%. Entretanto, a bananeira é uma planta que sofre grande influência das condições climáticas, como ventos, geadas e inundações (Moreira, 1999; Arruda et al., 1993). Além de doenças (mal-de-sigota, mal-dopanamá, moko ou murcha-bacteriana, viroses e doenças dos frutos) e pragas ("moleque" ou broca-da-banana, nematóides, tripes, traça-dos-frutos-dabananeira e largatas) (BT-CATI, 1998;Arruda, 1999). No caso de ocorrer algum desses imprevistos, a produtividade pode sofrer queda de $30 \%$.

Os valores estimados para os indicadores financeiros Valor Presente Líquido (VPL) e Receita Anual Equivalente (RAEq.), para diferentes taxas de desconto, para o caso de uma produção em condições climáticas favoráveis e sem a presença de doenças e pragas, podem ser observados na tabela 33. Os valores referentes ao VPL variam entre $\mathrm{R} \$ 8.021,00 \mathrm{ha}^{-1}$ (para taxa de desconto de 15\%) e R\$14.451,55 ha-1 (para taxa de desconto de 8\%). Estes valores correspondem a uma RAEq. de R\$1.281,50 ha ${ }^{-1}$ e R\$ $1.471,90 \mathrm{ha}^{-1}$, respectivamente. 
Tabela 32. Cultura da Banana Nanica: Estimativas de Custos, Receitas e Fluxo Líquido ao longo de 20 anos*, na região do Vale do Ribeira-SP, em R $\$$ ha (alta produtividade).

\begin{tabular}{|c|c|c|c|c|c|c|c|}
\hline \multirow{3}{*}{ Anos } & \multicolumn{4}{|c|}{ Despesas } & \multirow{3}{*}{ Custo Total } & \multirow{3}{*}{ Receitas } & \multirow{3}{*}{ Fluxo Líquido } \\
\hline & \multicolumn{2}{|l|}{ Operações } & \multirow[t]{2}{*}{ Insumos } & \multirow[t]{2}{*}{ Administração } & & & \\
\hline & Mecanizadas & Manuais & & & & & \\
\hline 1 & 1417,50 & 517,50 & 3727,50 & 522,50 & 6185,00 & 3053,70 & $-3131,30$ \\
\hline 2 & 280,00 & 1077,50 & 2090,00 & 672,50 & 4120,00 & 6107,40 & 1987,40 \\
\hline 3 & 337,50 & 1557,50 & 2222,50 & 760,00 & 4877,50 & 7897,50 & 3020,00 \\
\hline 4 & 337,50 & 1772,50 & 2557,50 & 805,00 & 5472,50 & 8775,00 & 3302,50 \\
\hline 5 & 337,50 & 1772,50 & 2557,50 & 805,00 & 5472,50 & 8775,00 & 3302,50 \\
\hline 6 & 1417,50 & 517,50 & 3727,50 & 522,50 & 6185,00 & 3053,70 & $-3131,30$ \\
\hline 7 & 280,00 & 1077,50 & 2090,00 & 672,50 & 4120,00 & 6107,40 & 1987,40 \\
\hline 8 & 337,50 & 1557,50 & 2222,50 & 760,00 & 4877,50 & 7897,50 & 3020,00 \\
\hline 9 & 337,50 & 1772,50 & 2557,50 & 805,00 & 5472,50 & 8775,00 & 3302,50 \\
\hline 10 & 337,50 & 1772,50 & 2557,50 & 805,00 & 5472,50 & $8775, .00$ & 3302,50 \\
\hline 11 & 1417,50 & 517,50 & 3727,50 & 522,50 & 6185,00 & 3053,70 & $-3131,30$ \\
\hline 12 & 280,00 & 1077,50 & 2090,00 & 672,50 & 4120,00 & 6107,40 & 1987,40 \\
\hline 13 & 337,50 & 1557,50 & 2222,50 & 760,00 & 4877,50 & 7897,50 & 3020,00 \\
\hline 14 & 337,50 & 1772,50 & 2557,50 & 805,00 & 5472,50 & 8775,00 & 3302,50 \\
\hline 15 & 337,50 & 1772,50 & 2557,50 & 805,00 & 5472,50 & 8775,00 & 3302,50 \\
\hline 16 & 1417,50 & 517,50 & 3727,50 & 522,50 & 6185,00 & 3053,70 & $-3131,30$ \\
\hline 17 & 280,00 & 1077,50 & 2090,00 & 672,50 & 4120,00 & 6107,40 & 1987,40 \\
\hline 18 & 337,50 & 1557,50 & 2222,50 & 760,00 & 4877,50 & 7897,50 & 3020,00 \\
\hline 19 & 337,50 & 1772,50 & 2557,50 & 805,00 & 5472,50 & 8775,00 & 3302,50 \\
\hline 20 & 337,50 & 1772,50 & 2557,50 & 805,00 & 5472,50 & 8775,00 & 3302,50 \\
\hline
\end{tabular}

\section{Fonte: CATI-Registro/SP $(2002)^{15}$}

* Produtividade estimada em 15,60 t/ha para o primeiro ano; 31 t/ha para o segundo ano; $40 \mathrm{t} / \mathrm{ha}$ para o terceiro ano; e, 45 t/ha para o quarto e quinto anos.

\footnotetext{
${ }^{15}$ Informações obtidas por meio de comunicação pessoal.
} 
Tabela 33. Cultura da Banana Nanica: Estimativas do Valor Presente Líquido (VPL) e a Receita anual Equivalente (RAEq.) ao longo de 20 anos*, na região do Vale do Ribeira-SP, em R \$/ha (alta produtividade).

\begin{tabular}{crr}
\hline Taxa de Desconto & VPL & RAEq. \\
\hline $8 \%$ & 14451,55 & 1471,92 \\
$10 \%$ & 12062,63 & 1416,87 \\
$12 \%$ & 10175,74 & 1362,32 \\
$15 \%$ & 8021,23 & 1281,48 \\
\hline
\end{tabular}

* Produtividade estimada em 15,60 t/ha para o primeiro ano; 31 t/ha para o segundo ano; 40 t/ha para o terceiro ano; e, 45 t/ha para o quarto e quinto anos.

Caso ocorram perdas no cultivo devido a mudanças climáticas e/ou pragas e doenças, os indicadores financeiros estimados são negativos para todas as taxas de desconto analisadas $(8 \%, 10 \%, 12 \%$ e $15 \%)$ (Tabela 35).

Considerando que o ciclo da caixeta seja de vinte anos, e que o valor da matagem seja $\mathrm{R} \$ 20,00 \mathrm{mst}^{-1}$, os valores estimados referentes ao VPL e a RAEq. podem ser observados na tabela 36. Para a taxa de desconto de 8\%, a variação no VPL fica entre $\mathrm{R} \$ 58,00 \mathrm{ha}^{-1}$ (áreas com 20 mst de madeira por ha) e $\mathrm{R} \$ 444,20 \mathrm{ha}^{-1}$ (áreas com 110 mst $\mathrm{ha}^{-1}$ ). As áreas com aproveitamento médio (40 e $60 \mathrm{mst} / \mathrm{ha}$ ) têm seus VPL estimados em R \$ 143,75 ha ${ }^{-1}$ e R $\$ 229,15$ ha $^{-1}$, respectivamente.

Logo, a rentabilidade da banana em condições de produção favoráveis, ou seja, com um aproveitamento de 90\% (VPL igual a R \$ 14.451,55 ha $^{-1}$ para taxa de $8 \%$ ), é muito superior a todos os cenários analisados para a caixeta. Como visto acima, a rentabilidade do manejo da caixeta para um aproveitamento da madeira "em pé" em torno de $40 \mathrm{mst} /$ ha é de cerca de $\mathrm{R} \$ 143,75 \mathrm{ha}^{-1}$, para a taxa de desconto de $8 \%$. Assim, em termos relativos o cultivo da banana é cerca de 100 vezes mais rentável que o manejo da caixeta, para um período de análise de vinte anos.

Entretanto, em relação aos impactos ecológicos que essas atividades causam no ecossistema a situação é inversa. As externalidades negativas geradas com o 
cultivo da banana estão associadas ao sistema de produção utilizado, que é caracterizado como um sistema de alta tecnologia e "input" (Waldhoff,1997). Assim, o uso de adubações, calagens, a construção de canais de drenagem e o bombeamento da água para fora do sistema prejudicam várias características da água e alteram o regime hidrológico (como a profundidade da água e os padrões de inundação) (Waldhoff,1997).

Tabela 34. Cultura da Banana Nanica: Estimativas de Custos, Receitas e Fluxo Líquido ao longo de 20 anos*, na região do Vale do Ribeira-SP, em R $\$$ ha (média produtividade).

\begin{tabular}{|c|c|c|c|c|c|c|c|}
\hline \multirow{3}{*}{ Anos } & \multicolumn{4}{|c|}{ Despesas } & \multirow{3}{*}{ Custo Total } & \multirow{3}{*}{ Receitas $^{2}$} & \multirow{3}{*}{ Fluxo Líquido } \\
\hline & \multicolumn{2}{|l|}{ Operações } & \multirow[t]{2}{*}{ Insumos } & \multirow[t]{2}{*}{ Administração } & & & \\
\hline & Mecanizadas & Manuais & & & & & \\
\hline 1 & 1417,50 & 517,50 & 3727,50 & 522,50 & 6185,00 & 2375,10 & $-3809,90$ \\
\hline 2 & 280,00 & 1077,50 & 2090,00 & 672,50 & 4120,00 & 4750,20 & 630,20 \\
\hline 3 & 337,50 & 1557,50 & 2222,50 & 760,00 & 4877,50 & 6142,50 & 1265,00 \\
\hline 4 & 337,50 & 1772,50 & 2557,50 & 805,00 & 5472,50 & 6825,00 & 1352,50 \\
\hline 5 & 337,50 & 1772,50 & 2557,50 & 805,00 & 5472,50 & 6825,00 & 1352,50 \\
\hline 6 & 1417,50 & 517,50 & 3727,50 & 522,50 & 6185,00 & 2375,10 & $-3809,90$ \\
\hline 7 & 280,00 & 1077,50 & 2090,00 & 672,50 & 4120,00 & 4750,20 & 630,20 \\
\hline 8 & 337,50 & 1557,50 & 2222,50 & 760,00 & 4877,50 & 6142,50 & 1265,00 \\
\hline 9 & 337,50 & 1772,50 & 2557,50 & 805,00 & 5472,50 & 6825,00 & 1352,50 \\
\hline 10 & 337,50 & 1772,50 & 2557,50 & 805,00 & 5472,50 & 6825,00 & 1352,50 \\
\hline 11 & 1417,50 & 517,50 & 3727,50 & 522,50 & 6185,00 & 2375,10 & $-3809,90$ \\
\hline 12 & 280,00 & 1077,50 & 2090,00 & 672,50 & 4120,00 & 4750,20 & 630,20 \\
\hline 13 & 337,50 & 1557,50 & 2222,50 & 760,00 & 4877,50 & 6142,50 & 1265,00 \\
\hline 14 & 337,50 & 1772,50 & 2557,50 & 805,00 & 5472,50 & 6825,00 & 1352,50 \\
\hline 15 & 337,50 & 1772,50 & 2557,50 & 805,00 & 5472,50 & 6825,00 & 1352,50 \\
\hline 16 & 1417,50 & 517,50 & 3727,50 & 522,50 & 6185,00 & 2375,10 & $-3809,90$ \\
\hline 17 & 280,00 & 1077,50 & 2090,00 & 672,50 & 4120,00 & 4750,20 & 630,20 \\
\hline 18 & 337,50 & 1557,50 & 2222,50 & 760,00 & 4877,50 & 6142,50 & 1265,00 \\
\hline 19 & 337,50 & 1772,50 & 2557,50 & 805,00 & 5472,50 & 6825,00 & 1352,50 \\
\hline 20 & 337,50 & 1772,50 & 2557,50 & 805,00 & 5472,50 & 6825,00 & 1352,50 \\
\hline
\end{tabular}

Fonte: CATI-Registro/SP (2002)

* Produtividade estimada em 12,20 t/ha para o primeiro ano; 24,40 t/ha para o segundo ano; 31,5 t/ha para o terceiro ano; e, 35 t/ha para o quarto e quinto anos. 
Os benefícios ambientais do manejo da caixeta são: a manutenção da qualidade dos recursos hídricos e da biodiversidade. Desta forma, a conservação, e preservação, dos caixetais contribui com o desenvolvimento do potencial produtivo da floresta.

Tabela 35. Cultura da Banana Nanica: Estimativas do Valor Presente Líquido (VPL) e da Receita anual Equivalente (RAEq.) ao longo de 20 anos*, na região do Vale do Ribeira-SP, em R \$/ha (média produtividade).

\begin{tabular}{crr}
\hline Taxa de Desconto & VPL & RAEq. \\
\hline $8 \%$ & $-168,63$ & $-17,18$ \\
$10 \%$ & $-513,70$ & $-60,34$ \\
$12 \%$ & $-770,65$ & $-103,17$ \\
$15 \%$ & $-1043,70$ & $-166,74$ \\
\hline
\end{tabular}

* Produtividade estimada em 12,20 t/ha para o primeiro ano; $24,40 \mathrm{t} / \mathrm{ha}$ para o segundo ano; $31,5 \mathrm{t} / \mathrm{ha}$ para o terceiro ano; e, 35 t/ha para o quarto e quinto anos.

Tabela 36. Valor Presente Líquido (VPL) e Receita Anual Equivalente (RAEq.) do manejo da caixeta para proprietários de terra da região do Vale do RibeiraSP, em R \$ por ha, para aproveitamento estimado de: 20 mst por ha; 30mst $\mathrm{ha}^{-1} ; 40 \mathrm{mst} \mathrm{ha}^{-1} ; 60 \mathrm{mst} \mathrm{ha}^{-1} ; \mathrm{e}, 110 \mathrm{mst} \mathrm{ha}^{-1}$. Valor da matagem estimado em $\mathrm{R} \$ 20,00$ por mst.

\begin{tabular}{crrrrr}
\hline VPL & 20 mst por ha & 30 mst por ha & 40 mst por ha & 60 mst por ha & 110 mst por ha \\
\hline $8 \%$ & 57,93 & 101,05 & 143,75 & 229,14 & 444,16 \\
$10 \%$ & 40,13 & 70,01 & 99,59 & 158,75 & 307,72 \\
$12 \%$ & 27,99 & 48,83 & 69,46 & 110,72 & 214,61 \\
$15 \%$ & 16,50 & 28,78 & 40,94 & 65,26 & 126,49 \\
RAEq. & & & & \\
$8 \%$ & 5,90 & 10,29 & 14,64 & 23,34 & 45,24 \\
$10 \%$ & 4,71 & 8,22 & 11,70 & 18,65 & 36,14 \\
$12 \%$ & 3,75 & 6,54 & 9,30 & 14,82 & 28,73 \\
$15 \%$ & 2,64 & 4,60 & 6,54 & 10,43 & 20,21 \\
\hline
\end{tabular}

Fonte: Dados da pesquisa 


\subsection{Ponto econômico ótimo de corte}

\subsubsection{Curva de crescimento}

A função logística (4) foi ajustada assumindo o valor de $250 \mathrm{~m}^{3} \mathrm{ha}^{-1}$ para a estimativa preliminar ( $a$ ) do parâmetro $\alpha$. Esse valor foi selecionado de acordo com os dados empíricos de levantamento dendrométrico efetuado no projeto Caixeta. Para corrigir o problema de heteroscedasticidade ${ }^{16}$, constatado pelo teste de Goldfeld-Quandt, foi aplicado o método de mínimos quadrados ponderados. Assim, na regressão de $\ln \left[\frac{Y i}{a-Y i}\right]$ contra $\mathrm{X} i,\left[\frac{(a-Y i)}{a}\right]^{2}$ foi usado como fator de ponderação.

Os resultados dos testes estatísticos, F e t, para o modelo de regressão linear ponderado ajustado, mostram que as estimativas obtidas são altamente significativas (Tabela 37). O valor de F (1,209 G.L.)=82,70 mostra que a hipótese nula $(\gamma=0)$ pode ser rejeitada ao nível de 0,01 . O valor de $R^{2}$ ajustado foi de aproximadamente $32,46 \%$.

Esse valor de $\mathrm{R}^{2}$ ajustado pode ser considerado como de razoável poder explicativo. No entanto, dado o fato de que existem problemas ${ }^{17}$ nos dados analisados, e que as observações são referentes a apenas quatro períodos, é compreensível o baixo poder explicativo da variável tempo. Além disso, o fato de a floresta de caixeta ser nativa faz com que os caixetais comumente apresentem uma distribuição irregular da espécie devido a fatores como: tipo de solo, principalmente em relação ao nível de alagamento da área; distância da fonte de propágulos de outras espécies arbóreas; e, histórico de perturbações ${ }^{18}$. Além das características ecológicas próprias de cada área de caixetal, outro aspecto que influencia em seu desenvolvimento (crescimento) é a realização de tratos silviculturais (como a desbrota) que permite a redução do impacto da

\footnotetext{
${ }^{16}$ As florestas de caixeta são caracterizadas como florestas heterogêneas devido ao fato de a espécie ser pioneira, ou seja, ocorre em agrupamentos. Isto faz com que ocorra alta variação entre o volume de madeira presente em cada parcela amostrada, fazendo com que a variância de cada termo de pertubação $u_{i}$ não seja constante e igual a $\sigma^{2}$.

${ }^{17}$ Existem razões para suspeitar que possam exister alguns problemas nos dados utilizados para estimar a curva de crescimento.

${ }^{18}$ Manual sobre manejo de caixeta do Laboratório de Silvicultura Tropical (LASTROP)/LCF/ESALQ-USP (não publicado).
} 
colheita sobre a floresta e o ambiente; melhoria do crescimento da floresta após a colheita; e, melhoria das condições de trabalho dos caixeteiros.

Aplicando o teste de Goldfeld-Quandt encontramos $\lambda=0,816$. Como o valor de $\mathrm{F}(=\lambda)$ estimado é inferior ao valor crítico, pode-se concluir não há heteroscedasticidade no modelo ajustado. Logo, a hipótese de homoscedasticidade não é rejeitada.

Tabela 37. Resultados das estimativas do modelo de regressão (Equação 10) do volume de caixeta em função do tempo.

\begin{tabular}{|c|c|}
\hline Variáveis Independente & Parâmetros Estimados \\
\hline \multirow[t]{2}{*}{$\beta$} & $-1,19651$ \\
\hline & $(-12,49)$ \\
\hline \multirow[t]{2}{*}{$\gamma$} & 0,04358 \\
\hline & (9.09) \\
\hline $\mathrm{R}^{2}$ & 0,3286 \\
\hline $\mathrm{ADJ}-\mathrm{R}^{2}$ & 0,3246 \\
\hline $\mathrm{F}(1,209)$ & 82,70 \\
\hline$\lambda(5,5)$ & 0,816 \\
\hline
\end{tabular}

* Valores do teste estatístico t em parentêses.

Substituindo os parâmetros estimados para $\alpha, \beta$ e $\gamma$, na função logística encontramos a curva de crescimento da caixeta (Figura 17). 


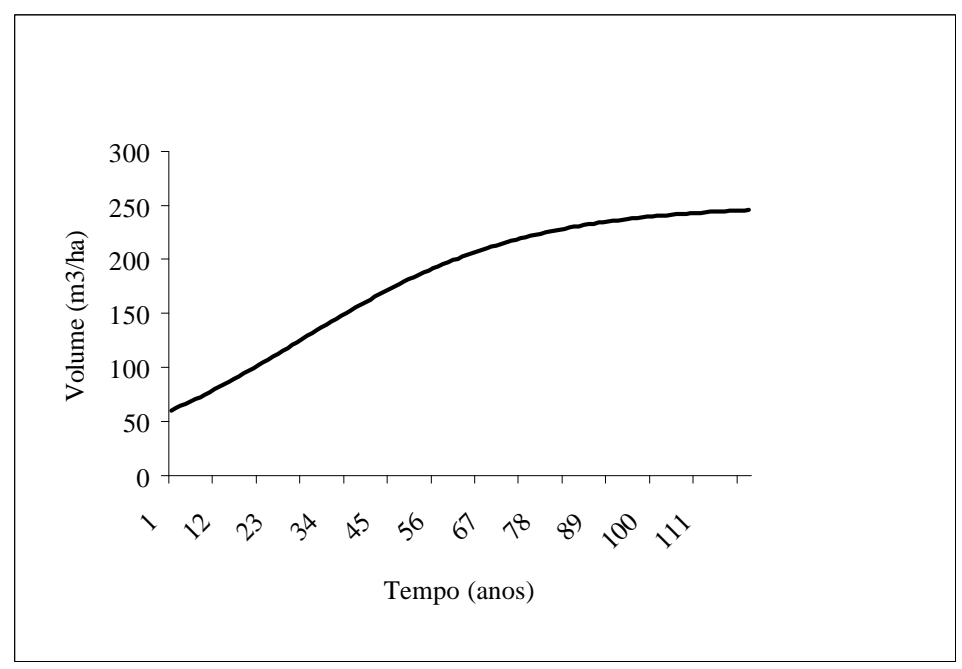

Figura 17 - Curva Estimada de Crescimento Acumulado da Caixeta

A derivada da função estimada em relação ao tempo resulta em uma função que fornece a quantidade de madeira produzida em cada ano (incremento anual do volume de madeira). Utilizando o critério de corte no ano em que esse valor é máximo, determina-se que a colheita da caixeta deverá ocorrer em torno de 30 anos (Figura 18).

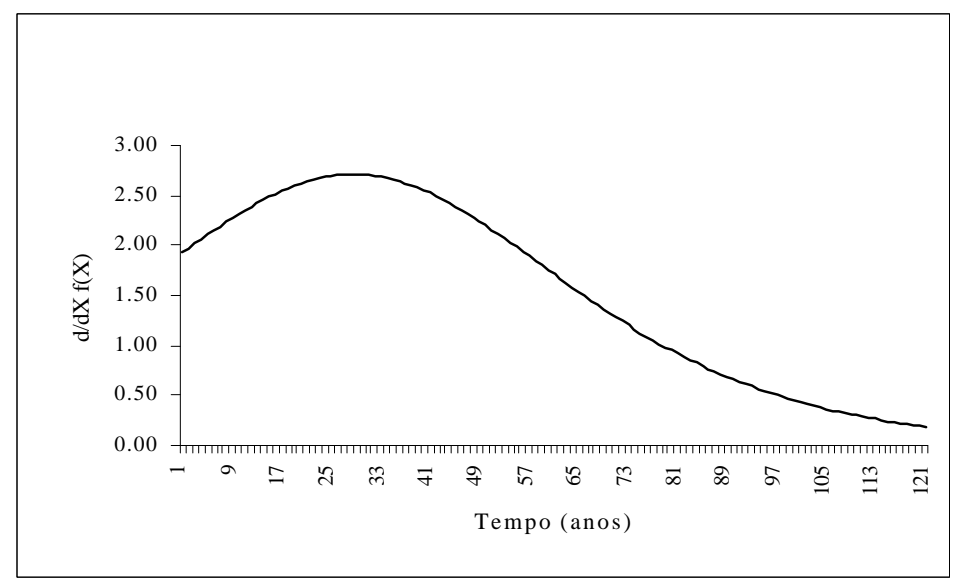

Figura 18 - Curva Estimada do Incremento Anual do Volume de madeira. 
Já, a relação entre essa derivada e a função logística estimada fornece a taxa de crescimento anual (Figura 19).

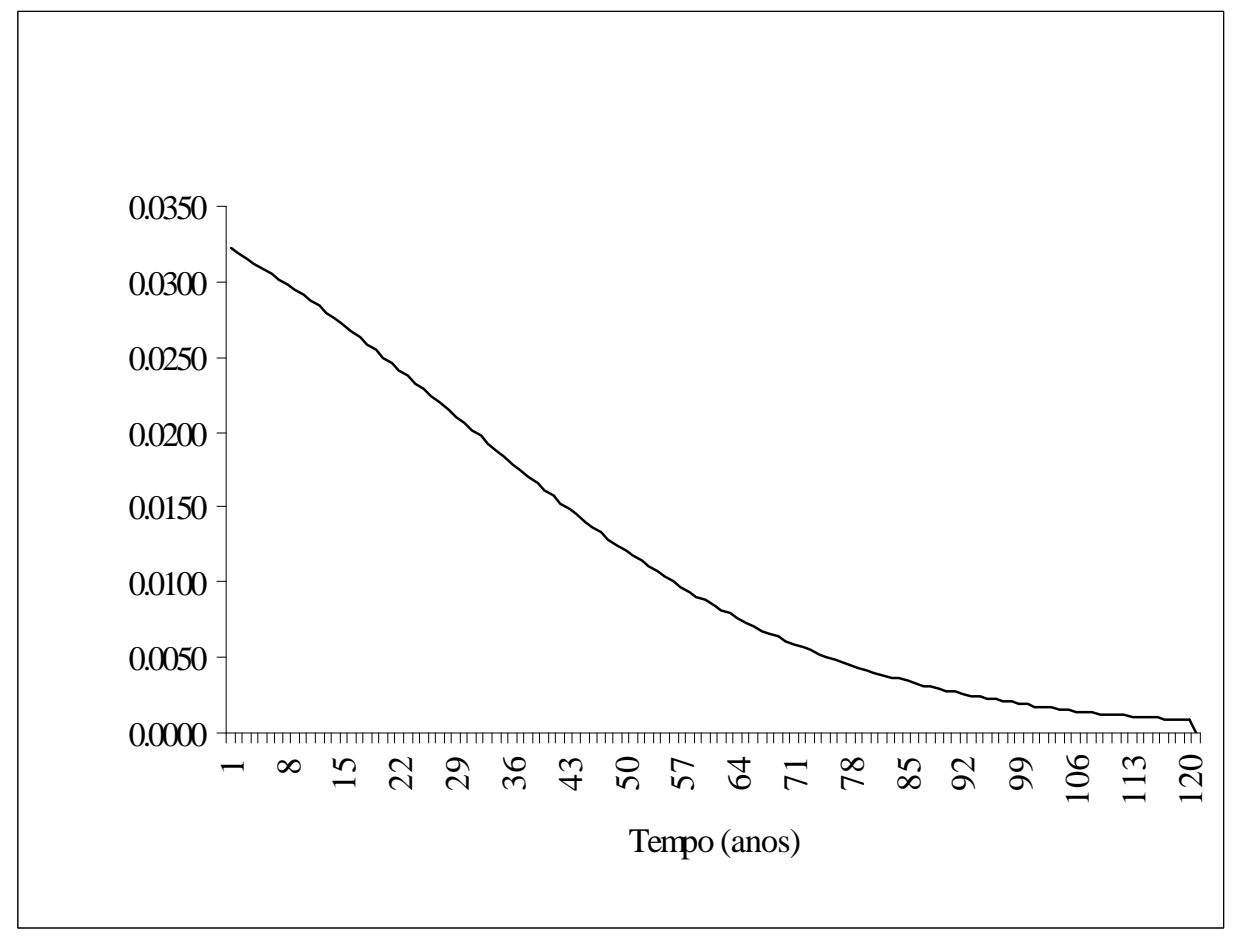

Figura 19 - Curva Estimada da Taxa de Crescimento Anual da Caixeta.

Observa-se que a taxa de crescimento da caixeta é decrescente ao longo de toda a sua vida. No início, do ciclo, seu crescimento é de aproximadamente 3\% aa., caindo para cerca de $2 \%$ aa, em torno dos 30 anos de idade. 


\section{CONCLUSÕES}

O presente estudo permite dois tipos de conclusões: as qualitativas e as quantitativas. Entre as conclusões qualitativas, destacam-se:

a) Desorganização da cadeia produtiva. Dentre os diversos problemas, o estudo constatou que não existe uma forma única de negociação entre os três agentes envolvidos: donos dos caixetais; caixeteiros; e, serrarias. O agente que encontra compradores interessados dá início às negociações. A inexistência de mecanismo eficiente de negociação entre esses agentes cria ineficiência de mercado;

b) Dificuldades burocráticas e legais na aprovação do plano de manejo (relacionadas com a estrutura fundiária da região, ou seja, a questão da posse legítima e documentada da terra, e com o processo de elaboração e aprovação do plano pelo DEPRN);

c) Ineficiência no funcionamento do segmento serraria, dificultando a abertura de novas oportunidades de mercado para a madeira da caixeta. A falta de administração empreendedora e a não acessibilidade (de proprietários de caixetal e caixeteiros) aos equipamentos disponíveis para o processamento primário da madeira, muitas vezes, impede que negociações sejam efetivadas;

d) Falta de mercado (demanda) e o baixo preço. Este problema poderia ser solucionados com a certificação da madeira, conforme verificado em pesquisa de mercado para produtos de caixeta realizada pelo IMAFLORA (1996 e 1997). O uso da madeira certificada da caixeta em produtos de alto valor agregado, como embalagens para perfume e outros, pode aumentar a demanda e o preço da 
madeira; e,

e) A localização geográfica dos caixetais é outro problema que dificulta o desenvolvimento do manejo da caixeta. O solo, normalmente alagado faz com que o processo de extração e de retirada da madeira da floresta tenha baixa produtividade e altos custos.

A ineficiência da cadeia produtiva da caixeta implica na escassez de dados e, logo, resulta em falta de informação. Esta característica, inclusive, dificulta a implantação de políticas públicas visando o apoio e sustentação da atividade.

$\mathrm{Na}$ área quantitativa, destacam-se:

a) Estimativa da curva de crescimento da caixeta, para determinar o ponto ótimo de corte do ponto de vista econômico;

b) A avaliação econômica da caixeta para proprietários de terra mostra que o proprietário que vende a madeira em toras no "porto" tem uma rentabilidade maior que o proprietário que vende a madeira "em pé".

Considerando um aproveitamento médio de $40 \mathrm{mst} / \mathrm{ha}$, (R $\$ 1.060,00 \mathrm{ha}^{-1}$ e $\mathrm{R} \$ 870,00 \mathrm{ha}^{-1}$ ), o proprietário que vende a madeira em toras no "porto" terá uma rentabilidade cerca de 1,22 vezes maior. Para o caso menor rentabilidade, $\mathrm{R} \$ 984,00 \mathrm{ha}^{-1}$ e R\$ 670,00 ha ${ }^{-1}$ a diferença é ainda maior: a diferença entre eles cresce para cerca $47 \%$.

No entanto, dado que uma equipe de caixeteiro recebe entre $\mathrm{R} \$ 138,00$ (áreas com alta produtividade) e $\mathrm{R} \$ 90,00$ (áreas com baixa produtividade) por dia de trabalho. Se considerarmos a diferença entre a rentabilidade desses proprietários como exposto acima, os proprietários que que também são caixeteiros estão recenbo cerca de R\$ 40,00 equipe/dia pelo trabalho de extração realizado em áreas de baixa produtividade, e cerca de $\mathrm{R} \$ 33,00$ equipe/dia em áreas com alta produtividade;

c) A rentabilidade da atividade para caixeteiros foi estimada em cerca de 6,0 salários mínimos por mês. A menor em torno de 3,0 salário/mês e a maior cerca de 4,5 salários/mês, sendo uma atraente fonte de renda quando comparada às alternativas existentes na região;

d) A baixa rentabilidade da atividade para os proprietários de terra, cerca de 100 vezes menor que o cultivo da banana, mostra que nas atuais condições de 
mercado, esses proprietários não possuem incentivo econômico para a manutenção e preservação das áreas de caixetais. Além do já citado esforço de buscar novos mercados mais remuneradores para a caixeta, uma outra forma de aumento da renda dos proprietários, e caixeteiros, é por meio do aproveitamento de epífitas e outros subprodutos. Entretanto, ainda não existem dados científicos a respeito da quantidade e variedade de espécies existentes que possam ser comercializadas. Nesse sentido, seria interessante realizar estudos científicos (técnicos e econômicos) visando quantificar esses recursos. Outra alternativa é a venda de certificados de sequestro de carbono. Porém, como no caso anterior, é necessário que se façam estudos adicionais, tanto técnicos como econômicos, para verificar sua viabilidade. 


\section{REFERÊNCIAS BIBLIOGRÁFICAS}

ALMEIDA, D.S. Recuperação ambiental da Mata Atlântica. Ilhéus: Editus, 2000. 130p.

ANDRIETTA, A.J. O Vale do Ribeira: realidades locais de seu desenvolvimento. Informações Econômicas, v.32, n.1, p.53-65, jan.2002.

ANDRIETTA, A.J. Realidade e pontencialidade dos agronegócios regionais do Vale do Ribeira. Informações Econômicas, v.32, n.3, p.35-49, mar. 2002.

ANGELSEN, A.; SHITINDI KATEMANSIMBA, E.F.; ARRESTAD, J.A. Why do farmers expand their land into forests? Theories and evidence from Tanzania. Environment and Development Economics, v.4, p.313-331, 1999.

ARRUDA, S.T.; PEREZ, L.H.; BESSA JUNIOR, A.A. A bananicultura no Vale do Ribeira: caracterização dos sistemas de produção. Agricultura em São Paulo, v.40, n.1, p.1-17, mar.1993.

BERCK, P. The economics of timber: a renewable resource in the long run. Bell Journal of Economics, v.100, p.447-462, 1979.

COORDENADORIA DE ASSISTÊNCIA TÉCNICA INTEGRAL. Cultura da banana. Campinas, dez. 1998. 37p. (CATI. Boletim Técnico, 234) 
BRASIL. Ministério do Meio Ambiente, dos Recursos Hídricos e da Amazônia Legal. Secretaria de Formulações de Políticas e Normas Ambientais. Diretrizes para a Política de Conservação e Desenvolvimento Sustentável da Mata Atlântica. Brasília, 1998. 30p.

BRASIL. Código Florestal. Lei 4.771/65 de 15 de setembro de 1965. http://www.ibamapr.hpg.ig.com.br/4771leiF.htm (20 ago. 2002).

BRASIL. Resolução CONAMA 01/94 de 31 de janeiro de 1994. http://www.lei.adv.br/001-94.htm (20 ago. 2002).

BRASIL. Decreto 750/93 de 10 de fevereiro de 1993. http://www.lei.adv.br/75093.htm (20 ago. 2002).

CARVALHO, P.E.R. Espécies florestais brasileiras: recomendações silviculturais, potencialidades e uso da madeira. Colombo: EMBRAPA, CNPF, 1994. 660p.

CLARK, C.W. Mathematica bioeconomics: the optimal management of renewable resource. New York: John Wiley, 1976. 352p.

CONTE, R.; REIS, M.S.; RIBEIRO, R.J. Estudo de parâmetros técnicos para o manejo sustentado da samambaia silvestre (RUMOHRA ADIANTIFORMIS). In: DIEGUES, A.C.S; VIANA, V.M. (Org.). Comunidades tradicionais e manejo dos recursos naturais da Mata Atlântica. São Paulo: USP, NUPAUB, 2000. parte I, p.29-42.

DIEGUES, A.C.S. (Coord.). A caixeta no Vale do Ribeira: estudo sócio-econômico da população vinculada à extração e ao desdobro da caixeta. São Paulo: USP, NUPAUB, 1991. 120p. 
DI STASI, L.C; STIPP, E.J.; FASCINELLI, M.L. et al. Agregação de valor a produtos florestais manejados: 1. Espinheira-santa e suas Adulterações 2. Pariparoba e outras Piperaceae como Novos produtos para comercialização. In: DIEGUES, A.C.S; VIANA, V.M. (Org.). Comunidades tradicionais e manejo dos recursos naturais da Mata Atlântica. São Paulo: USP, NUPAUB, 2000. parte I, p.65-80.

DUPUIT, J. "Public works and the Consumer". Baltimore: Murphy Denys, 1968. $333 p$.

EMPRESA BRASILEIRA DE PESQUISA AGROPECUÁRIA. Florestas. Indicadores econômicos e técnicos do Estado do Paraná e Santa Catarina. http://cnpf.embrapa.br (04 abr. 2002).

FLORES, E.J.M. Potencial produtivo e alternativas de manejo sustentável de um fragmento de Mata Atlântica secundária, município de Viçosa, Minas Gerais. Viçosa, 1993. 165p. Tese (Doutorado) - Universidade Federal de Viçosa.

FUNDAÇÃO SOS MATA ATLÂNTICA. Atlas da Mata Atlântica. http://www.sosmatatlantica.org.br/atlas2001/index.asp (15 mar. 2002).

GIORDANO, S.M. Desenvolvimento sustentável, meio ambiente e o Vale do Ribeira. In: SEMINÁRIO VITAE CIVILIS, São Pedro, 1995. Anais. São Pedro: Vitae Civilis, 1995. p.11.

GOMES-POMPA, A.; BURLEY, F.W. The management of natural tropical forests. Rain Forest Regeneration and Management. Paris: UNESCO, 1991. p.3-18. (Man and the biosphere series, 6)

CONÇALVES, J.S.; SOUZA, S.A.M. Agronegócio no Vale do Ribeira. Informações Econômicas, v.31, n.1, p.38-51, jan. 2001. 
HAMBURGUER, D.S.; CRISCUOLO, C. Levantamento de caixetais no município de Iguape. Rio Claro: UNESP, Depto. de Cartografia e Análise da Informação Cartográfica, 1995. 11p. (Relatório técnico apresentado a Fundação SOS Mata Atlântica)

HAMMOND, R.J. Benefit-cost analysis and water pollution control. Stanford: Stanford University Press, 1958. 198p.

HOFFMANN, R.; VIEIRA, S. Análise de regressão: uma introdução à econometria. São Paulo: HUCITEC, 1998. 379p.

HUFSCHIMDT, M.M.; JAMES, D.E.; MEISTER, A.D.; BOWER, B.F.; DIXON, J. A. Environment, natural systems and development. Baltimore: Johns Hopkins University Press, 1983. 338p.

INOUE, M.T.; RODERJAN, C.V.; KUNIYOSHI, Y.S. Projeto madeira do Paraná. Curitiba: Fundação de Pesquisas Florestais do Paraná, 1984. 80p.

INSTITUTO DE ECONOMIA AGRÍCOLA Preços agrícolas. http://www.iea.sp.gov.br/fpterra.htm (01 maio 2002)

INSTITUTO DE MANEJO E CERTIFICAÇÃO AGRÍCOLA E FLORESTAL. Relatório das atividades de pesquisa de mercado para produtos ecológicos da Mata Atlântica. Piracicaba: IMAFLORA, 1996. 10p. (Relatório de Pesquisa)

INSTITUTO DE MANEJO E CERTIFICAÇÃO AGRÍCOLA E FLORESTAL. Relatório das atividades de pesquisa de mercado para produtos ecológicos da Mata Atlântica. Piracicaba: IMAFLORA, 1997. 23p. (Relatório de Pesquisa) 
LAMPRECHT, H. Silvicultura nos trópicos: ecossistemas florestais e respectivas espécies arbóreas: possibilidades e métodos de aproveitamento sustentado. Eschborn: Universidade de Gottingen, Instituto de Silvicultur, 1990. 34p.

LEPSCH, I.F.; SARAIVA, I.R.; DONZELI, P.L.; MARINHO, M.A.; SAKAI, E.; GUILLAUMON, J.R.; PFEIFER, R.M.; MATTOS, I.F.A.; ANDRADE, W.J.; SILVA, C.E.F. Macrozoneamento das terras da região do Rio Ribeira de Iguape, S. P. Campinas: Instituto Agronômico de Campinas, 1990. 181p.

LESLIE, A.J. The economic feasibility of natural management of tropical forests. In: MERGEN, F.; VINCENT, J.R. (Ed.). Natural management of Tropical Moist Forests: silvicultural and management prospects of sustained utilization. Connecticut: Yale University, 1987. p.177-198.

LORENZI, H. Árvores brasileiras: manual de identificação e cultivo de plantas arbóreas nativas do Brasil. São Paulo: Plantarum, 1992. 355p.

MARQUESINI, M. Manejo de populações naturais de caixeta: Tabebuia cassinoides (Lam.) DC - fase I, Levantamento de caixetais. Piracicaba: USP, NUPAUB, Fundação Ford, 1994. 48p. (Relatório de Pesquisa do "Projeto Caixeta")

MARQUESINI, M.; VIANA, V.M. Relatório do projeto "Ecologia e manejo de populações naturais de caixeta-tabebuia cassinoides (Lam.) DC" Piracicaba: USP, ESALQ/Fundação Ford, 1995. 32p.

MARQUESINI, M.; PINHEIRO, L.; ARMELIN, M. Ocorrência de caixetais no município de São Paulo - S. P. Piracicaba: USP, ESALQ, 1996. 23p. (Relatório de pesquisa) 
MARQUESINI, M.; VIANA, V.M.; PAULO, R.A.; TROVÓ, M.F. Planos de manejo florestal de caixeta - Tabebuia cassinoides (LAM) DC. Iguape: Proter/USP, ESALQ, 1998. 34p. (Relatório do sub-projeto "Manejo sustentável de populações naturais de caixeta e implantação de uma serraria comunitária")

MOREIRA, R.S. Banana: teoria e prática de cultivo. São Paulo: Fundação Cargill, 1999. 335p.

NOLASCO, A.M. Resíduos da colheita e beneficiamento da caixeta-Tabebuia cassinoides (Lam.) DC.: caracterização e perspectivas. São Carlos, 2000. 171p. Tese (Doutorado) - Escola de Engenharia de São Carlos, Universidade de São Paulo.

NOLASCO, A.M.; ARMELIN, M.J.C. Artesãos da Mata Atlântica: módulo São Sebastião. Piracicaba: USP, ESALQ, 1997. 39p. (Relatório de pesquisa do Projeto "Artesãos da Mata Atlântica")

NOLASCO, A.M.; MARTINS, G.M.; MUNIZ, M.R.A. Artesãos da Mata Atlântica: módulo Parati. Piracicaba: USP, ESALQ, 1999. 37p. (Relatório de pesquisa do Projeto "Artesãos da Mata Atlântica”)

NORONHA, J.F. Projetos agropecuários, administração financeira, orçamentação e avaliação econômica. Piracicaba: FEALQ, 1981.274p.

NORONHA, J.F.; NEVES, E.M.; SHIROTA, R.; AZEVEDO, A.J.; CASTRO, A.M. Custo de produção de borracha natural em seringais nativos. Piracicaba: FEALQ/SUDHEVEA/EMBRAPA, 1983. 68p. (Relatório de pesquisa)

PEARCE, D.W. Economics of natural resources and the environment. Baltimore: Johns Hopkins University Press, 1990. 378p. 
PETERS, C.; GENTRY, A.; MENDELSOHN, R. Valuation of na Amazonian rainforest. Nature, v.339, p.655-656, 1989.

PINEDO-VASQUEZ, M.; ZARIN, D.; JIPP, P. Economic returns from forest conversion in the Peruvian amazon. Ecological Economics, v.6, n.2, p.163-173, 1992.

PROGRAMA DA TERRA. Relatório do plano estratégico de negócios dos produtos da caixeta. Registro: PROTER, 2001. 68p. (Relatório de pesquisa)

RAMOS, C.E.A. A utilização da caixeta na fabricação de lápis: histórico e perspectivas. In: WORKSHOP MANEJO DA CAIXETA E POLÍTICAS PARA O DESENVOLVIMENTO SUSTENTÁVEL NA REGIÃO DE IGUAPE, Piracicaba, 1994. A utilização da caixeta na fabricação de lápis: histórico e perspectivas. Piracicaba: USP, ESALQ, 1994. p.2.

RICKER, M.; DALY, D. C. Botánica económica en bosques tropicales: principios y métodos para su estudio y aprovechamiento. México: Editorial Diana, 1998. 293p.

RICKER, M.; MENDELSOHN, R.O.; DALY, D.C.; ÁNGELES, G. Enriching the rainforest with native fruit trees: an ecological and economic analysis in Los Tuxtlas (Veracruz, Mexico). Ecological Economics, v.31, n.3, p.439-448, 1999.

RIZZINI, C.T. Árvores e madeiras úteis do Brasil. São Paulo: Edgar Blucher, 1971. 294 p.

ROCK, M.T. The stork, the plow, rural social structure and tropical deforestation in poor countries? Ecological Economics, v.18, n.2, p.113-131, 1996. 
ROCHA FILHO, G.N. Iguape: levantamento sistemático destinado a inventariar bens culturais do estado de São Paulo. São Paulo: Condephaat, 1981. 25p.

SALES, R.R.; MARETTI, C.C.; PORTILHO, W.G. et al. Programa de recuperação da exploração comercial do palmito Juçara EUTERPE EDULIS. In: DIEGUES, A.C.S.; VIANA, V.M. (Org.). Comunidades tradicionais e manejo dos recursos naturais da Mata Atlântica. São Paulo: USP, NUPAUB, 2000. parte I, p.81-88.

SALES, R.R.; MALDONADO, W.T.P. A reserva extrativista estadual do bairro mandira e o ordenamento da exploração de ostras em Cananéia/SP. In: DIEGUES, A.C.S.; VIANA, V.M. (Org.). Comunidades tradicionais e manejo dos recursos naturais da Mata Atlântica. São Paulo: USP, NUPAUB, 2000. parte II, p.179-190.

SÃO PAULO (Estado). Secretaria do Meio Ambiente. Departamento Estadual de Proteção de Recursos Naturais. Programa de educação ambiental do Vale do Ribeira /São Paulo (SP). São Paulo, 1989. 10v. (Série educação ambiental)

SÃO PAULO (Estado). Secretaria de Estado do Meio Ambiente. Coordenadoria de Educação Ambiental. Serra do Mar: uma viagem à Mata Attântica. São Paulo, 1992. 94p. (Série educação ambiental)

SCHULZE, P.C.; LEIGHTON, M.; PEART, D.R. Enrichment planting in selectively logged rain forest: a combined ecological and economic analysis. Ecologycal Applications, v.4, n.3, p.581-592, 1994.

SÃO PAULO (Estado). Secretaria de Agricultura e Abastecimento. Valor da produção. http://www.agricultura.sp.gov.br/secr.htm (01 maio 2002). 
SILVA, M.M.P. Subsídios para o manejo de Tabebuia cassinoides (Lam.) DC (Caixeta): ecologia, silvicultura e manejo florestal. Piracicaba, 2000. 105p. Dissertação (Mestrado) - Escola Superior de Agricultura “Luiz de Queiroz”, Universidade de São Paulo.

VERISSIMO, A.; BARRETO, P.; MATTOS, M.; TARIFA, R.; UHL, C. Logging impacts and prospects for sustainable forest management in na old Amazonian frontier: the case of Paragominas. Forest Ecology and Management, v.55, n.1-4, p.169-1999, 1992.

VERISSIMO, A.; BARRETO, P.; TARIFA, R.; UHL, C. Extraction of a high-value natural resource in amazonia: the case of mahogany. Forest-Ecology and Management, v.72, n.1, p.39-60, 1995.

VIANA, V.M.; AZEVEDO, T.R.; MARQUESINI, M. Perspectivas para a certificação sócio-ambiental (Selo verde) e manejo da caixeta (Tabebuia cassinoides). Florestar Estatístico, v.3, n.9, p.14-20, 1996.

VIANA, V.M.; NOLASCO, A. O bom uso da floresta. Notícias FAPESP, n.44, p.24-6, jul. 1999.

VITAE CIVILIS. Plataforma ambiental mínima para o desenvolvimento do Vale do Vale do Ribeira. São Paulo, 1995. 19p.

UHL, C.; VERISSIMO, A.; MATTOS, M.M.; BRANDINO, Z.; VIEIRA, I.C.G. Social, economic, and ecological consequences of selective logging in an Amazon frontier: the case of Tailândia. Forest Ecology and Management, v.46, n.3-4, p.243-273, 1991. 
WALDHOFF, P. Impactos do manejo e conversão de caixetais sobre parâmetros físicos e químicos da água. São Carlos, 1997. 127p. Dissertação (Mestrado) - Escola de Engenharia de São Carlos, Universidade de São Paulo. 